
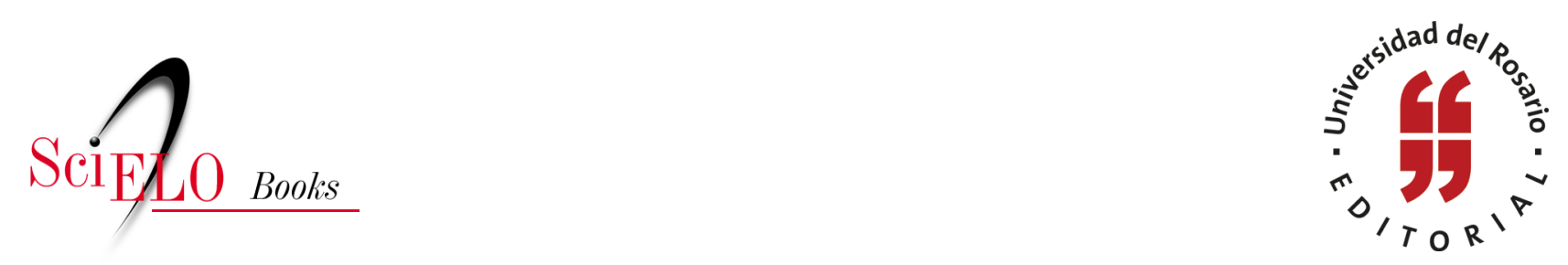

\title{
Construcción y significación del territorio. Comunidad El Codito, 2011
}

\author{
Juan David Guevara Salamanca \\ Miguel Hernández García \\ Mónica Alexandra Mendoza Molina
}

SALAMANCA, J.D.G., GARCÍA, M.H., and MOLINA, M.A.M. Construcción y significación del territorio. Comunidad El Codito, 2011 [online]. Bogotá: Editorial Universidad del Rosario, Instituto Rosarista de Acción Social - SERES, 2013, 132 p. ISBN 978-958-784-206-7.

https://doi.org/10.7476/9789587842067.

All the contents of this work, except where otherwise noted, is licensed under a Creative Commons Attribution 4.0 International license.

Todo o conteúdo deste trabalho, exceto quando houver ressalva, é publicado sob a licença Creative Commons Atribição $\underline{4.0}$.

Todo el contenido de esta obra, excepto donde se indique lo contrario, está bajo licencia de la licencia Creative Commons $\underline{\text { Reconocimento } 4.0 .}$. 


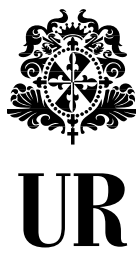




\section{Construcción y significación del territorio Comunidad El Codito, 2011}




\title{
Construcción y significación del territorio Comunidad El Codito, 2011
}

\author{
Juan David Guevara Salamanca \\ Miguel Hernández García \\ Mónica Alexandra Mendoza Molina
}


Construcción y significación del territorio. Comunidad El Codito, 2011 / Juan David Guevara Salamanca, Miguel Hernández García, Mónica Alexandra Mendoza Molina. —Bogotá: Editorial Universidad del Rosario, Instituto Rosarista de Acción Social -SERES-. 2013.

$132 \mathrm{p}$.

ISBN: 978-958-738-354-6

El Codito (Bogotá, Colombia) - Situación socioeconómica / Pobreza - El Codito (Bogotá, Colombia) / Violencia - El Codito (Bogotá, Colombia) / Bogotá (Colombia) - Política social/ I. Universidad del Rosario, Instituto Rosarista de Acción Social-SERES- / I. Título.

$362.57098614 \quad$ SCDD 20

Catalogación en la fuente - Universidad del Rosario. Biblioteca

amv

Abril 25 de 2013

Hecho el depósito legal que marca el Decreto 460 de 1995

Instituto Rosarista de Acción Social "Rafael Arenas Ángel”, -SERES-

(C) 2013 Editorial Universidad del Rosario

(C) 2013 Universidad del Rosario, Instituto Rosarista de Acción Social -SERES-

(C) 2013 Juan David Guevara Salamanca, Miguel Hernández García,

Mónica Alexandra Mendoza Molina

Editorial Universidad del Rosario

Carrera 7 No. 12B-41, of. 501 • Tel. 2970200 ext. 7724

http:// editorial.urosario.edu.co
Primera edición: Bogotá, D.C., mayo de 2013

ISBN: 978-958-738-354-6

Coordinación editorial: Editorial Universidad del Rosario Corrección de estilo: Liliana Gaona

Diagramación: Precolombi EU-David Reyes

Diseño e imagen de cubierta: Kilka Diseño Gráfico

Impresión: Xpress. Estudio Gráfico y Digital

Impreso y hecho en Colombia

Printed and made in Colombia

Fecha de evaluación: 16 de enero de 2013 | Fecha de aprobación: 02 de abril de 2013

Todos los derechos reservados. Esta obra no puede ser reproducida sin el permiso previo por escrito de la Editorial Universidad del Rosario. 


\section{Índice}

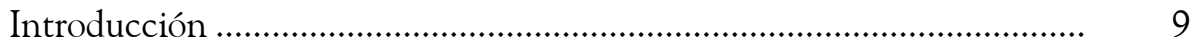

Entre la fragilidad y la vigencia. Una reflexión sobre la comunidad.

Caso El Codito ............................................................................ 2

Mónica Mendoza Molina

Aproximaciones a la conformación histórica del territorio de

El Codito. Del estatisismo normativo a la construcción social.......... 55

Juan David Guevara Salamanca

Adulto mayor y construcción de comunidad

101

Miguel Hernández García

Conclusión general 


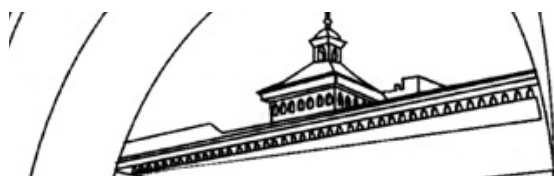




\section{Introducción}


Los acontecimientos publicitados a comienzos del año 2013 dan cuenta de la fragilidad y vulnerabilidad de los cerros orientales de Bogotá. Esta fragilidad no solo se deriva de los incidentes de seguridad que dirigieron las miradas hacia esta zona de la ciudad, sino, además, al estado de sobrevivencia, fragilidad y penuria que muchos de sus habitantes sortean día a día. Indiscutiblemente, los fenómenos y hechos de inseguridad que tuvieron lugar en los cerros orientales de Bogotá, en especial los sucesos en los barrios de Santa Cecilia, Villa Nidia y en el sector El Codito (compuesto por 17 barrios), prendieron las alarmas de las autoridades que con inexplicable eficiencia volcaron sus instituciones sobre la coyuntura de homicidios ocurridos en estos territorios.

Aludimos la inexplicable reacción debido a que este tipo de hechos no son novedosos para los habitantes de estas zonas. El miedo y la incertidumbre han estado presentes en un buen número de ocasiones, sin que se produzca una respuesta efectiva e integral que resuelva o aminore la vulnerabilidad que pesa sobre los pobladores de esta parte de la ciudad.

Estos hechos pudieran ser elementos disociados, inconexos y separados —no necesariamente deben ser explicados a la luz de simples retaliaciones entre grupos o bandas criminales-, lo que no quiere decir que sean menos especiales o poco importantes. Pueden ser, a su vez, situaciones relacionadas con la posición geográfica y la importancia que tienen los cerros al ser frontera limítrofe de la ciudad y Cundinamarca o al simple hecho que la marginalización trae consigo nuevos órdenes territoriales. Nuestro propósito no es indagar o proponer una lectura sobre el fenómeno de violencia y situaciones de inseguridad generadas en los últimos tiempos.

El interés propio de este trabajo es indagar y recomponer parte de la invaluable historia de luchas sociales y defensa del sector El Codito que los pobladores de estas espacialidades recomponen diariamente. Este proceso de transformación no solo del territorio, como espacio físico, sino de las interacciones sociales que al interior de los grupos asentados en esos espacios se generan fue el elemento de indagación que da cuerpo a este texto.

Específicamente, lo que se pretende en este libro es indagar por las primeras relaciones compositoras de los elementos comunitarios en los 
territorios de El Codito, cuyo actor fundamental ha sido el relato sobre el constructo de comunidad.

El presente texto, compuesto por tres partes, es uno de los resultados de un trabajo de investigación participativa, realizado por la Universidad del Rosario, a través de su Instituto Rosarista de Acción Social (Seres) y del Equipo Interdisciplinario de Estudios en Desarrollo Local, ${ }^{1}$ en El Codito de la ciudad de Bogotá. Desde el año 2007, se vienen adelantando acciones en este lugar, como parte de la política de responsabilidad social adelantada por la Universidad, que procuran la consolidación de redes de apoyo comunitarias, el empoderamiento de diferentes grupos poblacionales y la implementación de estrategias para el desarrollo local.

En su primer capítulo, los textos de este capítulo se adentran en la identificación de los elementos históricos que moldearon el sector de El Codito. El segundo capítulo indaga sobre el constructo de comunidad y su relación con este territorio. El tercer capítulo pretende exponer elementos actuales que se presentan en el sector desde una mirada crítica, actual y globalizada, que obedece a una revisión externa de un pasante internacional que aporta para entablar diálogos más allá de las fronteras nacionales.

Estos textos no buscan responder de manera sistemática o concatenada a una pregunta orientadora del libro. Son textos autónomos e independientes que respetan los estilos de los autores y actores inmersos en la contrucción de los textos.

El enlace fundamental del texto se encuentra en la relación existente entre comunidad y territorio para el caso de El Codito; lo último se refuerza con el énfasis en permitir que la voz silenciada de los primeros habitantes del sector sea escuchada, por eso los textos fueron elaborados a partir de la voz y referencias de los adultos mayores y de los primeros pobladores de los principales barrios.

Con este material se pretende rescatar los elementos particulares de la lucha social por el territorio, recuperar el significado simbólico de este y

\footnotetext{
1 Este equipo está conformado por representantes de la facultad de Ciencia Política y Relaciones Internacionales, la Escuela de Ciencias Humanas, la Escuela de Ciencias de la Salud, a través del programa de Terapia Ocupacional, la Cancillería de la Universidad del Rosario y el Instituto Rosarista de Acción Social Rafael Arenas Ángel (Seres).
} 
del constructo de comunidad (si es que realmente existió para el caso de El Codito) y dar espacio y voz a la visión de los pobladores inciales del sector. El primer capítulo se centra en el aspecto del territorio, realizando un recorrido histórico general por la conformación de Bogotá como ciudad, de Usaquén como localidad y un recorrido específico de El Codito como proceso histórico barrial y como territorio significado. Es sumamente importante para ello, la definición de los cerros de Bogotá como escenario de conflicto, con contenido simbólico muy alto, en el que convergen intereses de múltiples grupos. En el capítulo se plasma el proceso de poblamiento de la zona, que varía sustancialmente de un barrio a otro y que, igualmente, está determinado por la presencia y los modos de operar de diversos actores sociales.

La mayoría de participantes en estos espacios son habitantes que dieron origen al sector, por lo que sus aportes y vivencias fueron vitales para la reconstrucción de su historia y memoria, vista, por supuesto, desde sus ojos, remembranzas, experiencias, anhelos y frustraciones. Este capítulo también pretende establecer la relación de este grupo particular con el territorio, sus barrios y lugares significativos.

En el segundo capítulo, se desarrolla el concepto de comunidad partiendo de su caracterización tradicional, hasta llegar a sus connotaciones actuales, que establecen un paralelo con aspectos encontrados en El Codito, de acuerdo a la narrativa de uno de los grupos poblacionales que lo componen. El acercamiento a esta población particular, se inició en el año 2007 y, desde allí, se han fortalecido los lazos de colaboración y confianza con la Universidad, a través de la realización de un taller productivo y de la implementación de talleres de alfabetización para adultos mayores.

La mirada específica sobre el territorio obedece a un interés compartido con líderes comunales y algunos pobladores en recuperar parte de la memoria histórica y las luchas sociales que han implicado el asentamiento en esta zona particular de la ciudad. Teniendo en cuenta las presiones de distinto orden sobre el territorio y sus pobladores en particular, el estudio histórico sobre la conformación de los barrios y sus pobladores puede conducir a que se lleve a un acercamiento de distinto orden al que se pretende realizar con sus pobladores. 
Parte de las acciones de la Universidad del Rosario en este lugar, se realizan en el marco de convenios con otras instituciones, de esta manera, el tercer capítulo es el resultado de un trabajo realizado por un pasante de la Universidad Carlos III de Madrid, quien, a través de su experiencia en El Codito, de su trabajo de campo y su labor investigativa, realiza un análisis de las formas de construcción de comunidad, a través de variables como la cotidianidad, el sentido de pertenencia, el género y la participación.

Este trabajo fue posible gracias al apoyo permanente de la comunidad de El Codito, que a través de todos estos años ha demostrado su disposición e interés para trabajar de la mano con la Universidad del Rosario, en aras del desarrollo local.

\section{El Codito}

El Codito se ubica en el extremo norte de la ciudad de Bogotá, sobre los cerros orientales que delimitan a la capital de Colombia; con sus 17 barrios, es uno de los sectores que componen la localidad número uno de Usaquén.

Como se puede observar en el mapa 1 de Bogotá, la localidad de Usaquén está referenciada con una sombra, cuyos límites son: al sur la calle 100, al occidente la autopista norte, al norte el municipio de Chía y al oriente el municipio de La Calera. La flecha señala la ubicación del sector al interior de la localidad y de la ciudad.

La división territorial que en este libro se expone y en el trabajo realizado a lo largo de estos años, por parte del equipo interdisciplinario de Estudios en Desarrollo Local y del Instituto Rosarista de Acción Social, ha buscado preservar y respetar la construcción social del territorio. Por ello y aunque todo límite sobre el territorio es difuso, hemos querido tomar el riesgo de presentar la división del territorio que, de acuerdo con sus habitantes, se presenta actualmente.

Es meritorio resaltar que la división aquí presentada es tan solo una aproximación a la cartografía, los relatos y la percepción que los habitantes y planeadores urbanos tienen sobre El Codito y los distintos barrios que lo componen. 


\section{Mapa 1. Localidad de Usaquén}

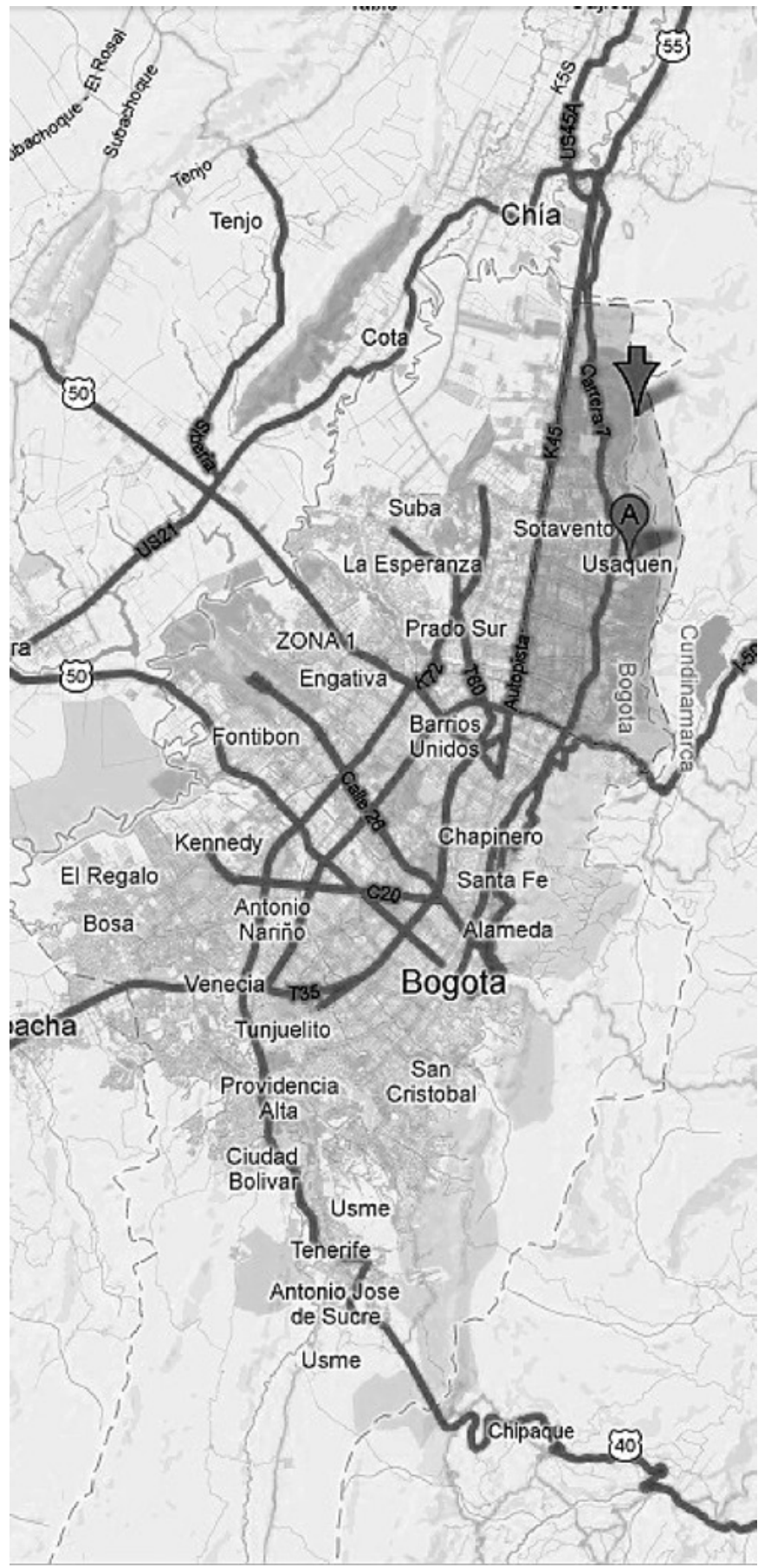

Tomado de: https://maps.google.ca. 2013. 


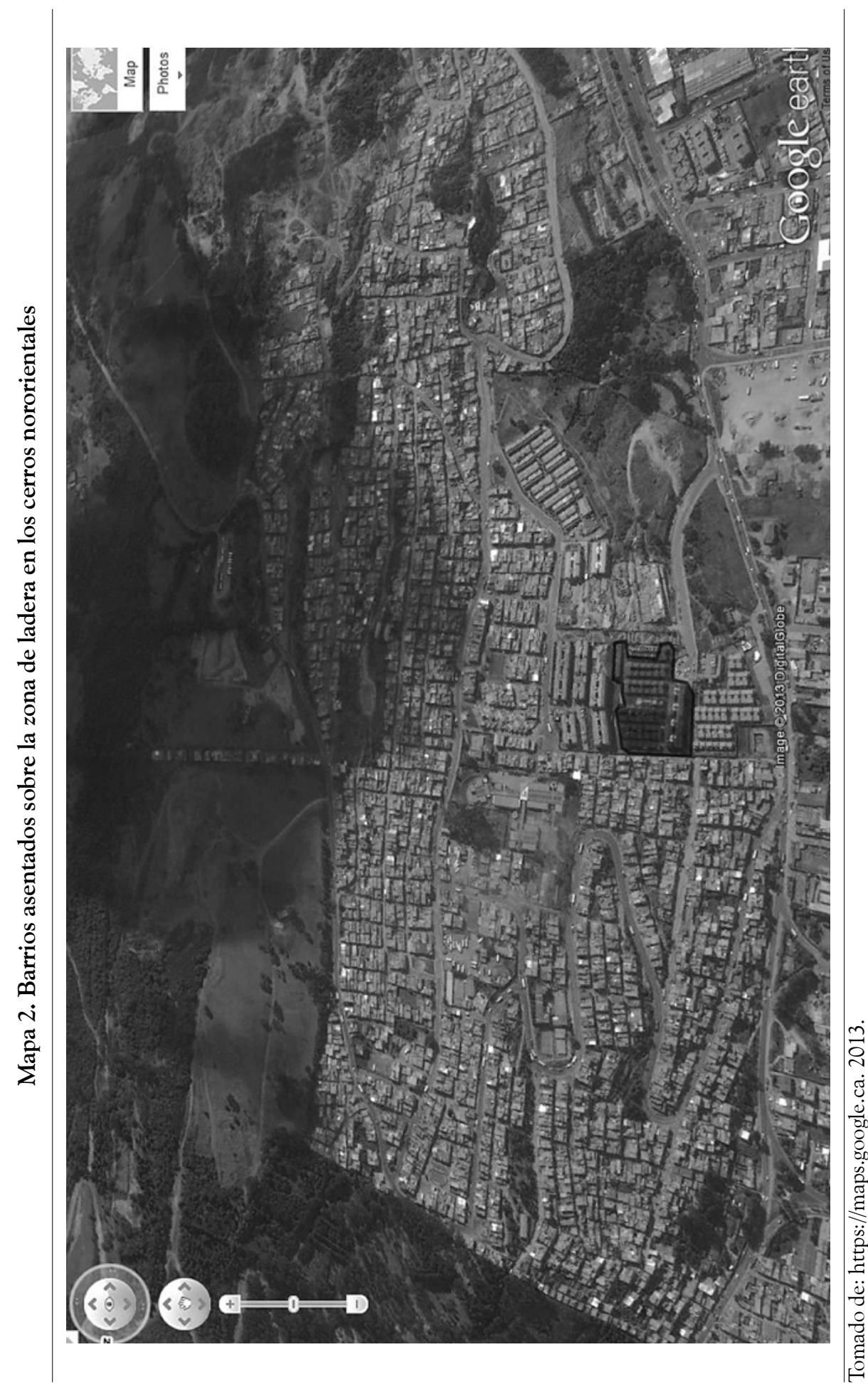


La imagen del mapa 2, tomada de googlemaps, da cuenta de los barrios que se asientan sobre la zona de ladera en los cerros nororientales bogotanos.

Sobre la parte alta de la montaña se encuentran tres barrios que hacen parte en su carácter identitario del sector. Sin embargo, la imagen satelital no permite dar cuenta de ellos debido a las condiciones nubladas del día en que la foto fue tomada.

El mapa 3 muestra los barrios con sus nombres y divisiones territoriales. Buenavista sectores I y II, Balcones de Vista Hermosa, Estrellita del Norte, Las Mercedes, La Franja, Llanurita I y II, Mirador del Norte-parte alta, Mirador del Norte, Horizontes, Chaparral, Nuevo Horizontes y El Codito.

El lector puede observar que existen tres espacios encerrados dentro de los límites del sector pero sin ningún nombre que permita identificarlos. El espacio situado entre los barrios Mirador del Norte, Horizontes y Estrellita del Norte es el parque más grande que tiene la zona. El otro espacio "sin nombre" es el espacio situado entre los barrios Las Mercedes y Llanurita I, allí se ubica el colegio Don Bosco III y una planta de bombeo del acueducto. El último espacio se sitúa en la parte baja del mapa, el lector podrá observar las edificaciones sombreados corresponden a los apartamentos que, para algunos habitantes, no son parte esencial del ritmo y la dinámica del sector, para otros, los lazos de familiaridad y parentesco con residentes de estos conjuntos cerrados hace que no se les excluya del devenir de El Codito.

Estos espacios anteriormente referenciados fueron dejados sin nombre de forma discrecional por los autores del libro por desconocimiento de las denominaciones sociales y por facilidades prácticas en el momento de escribir los nombres en el mapa. 


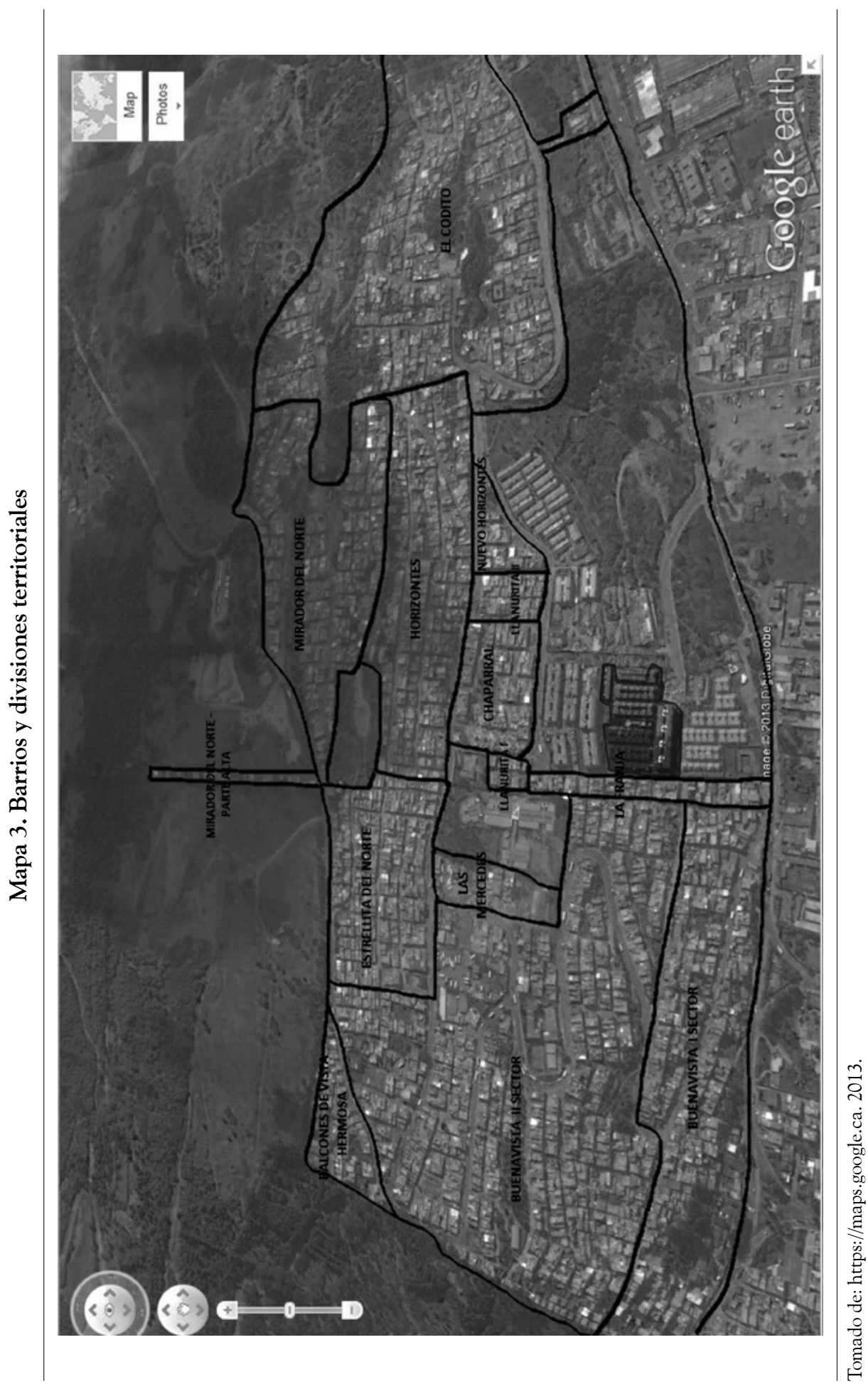




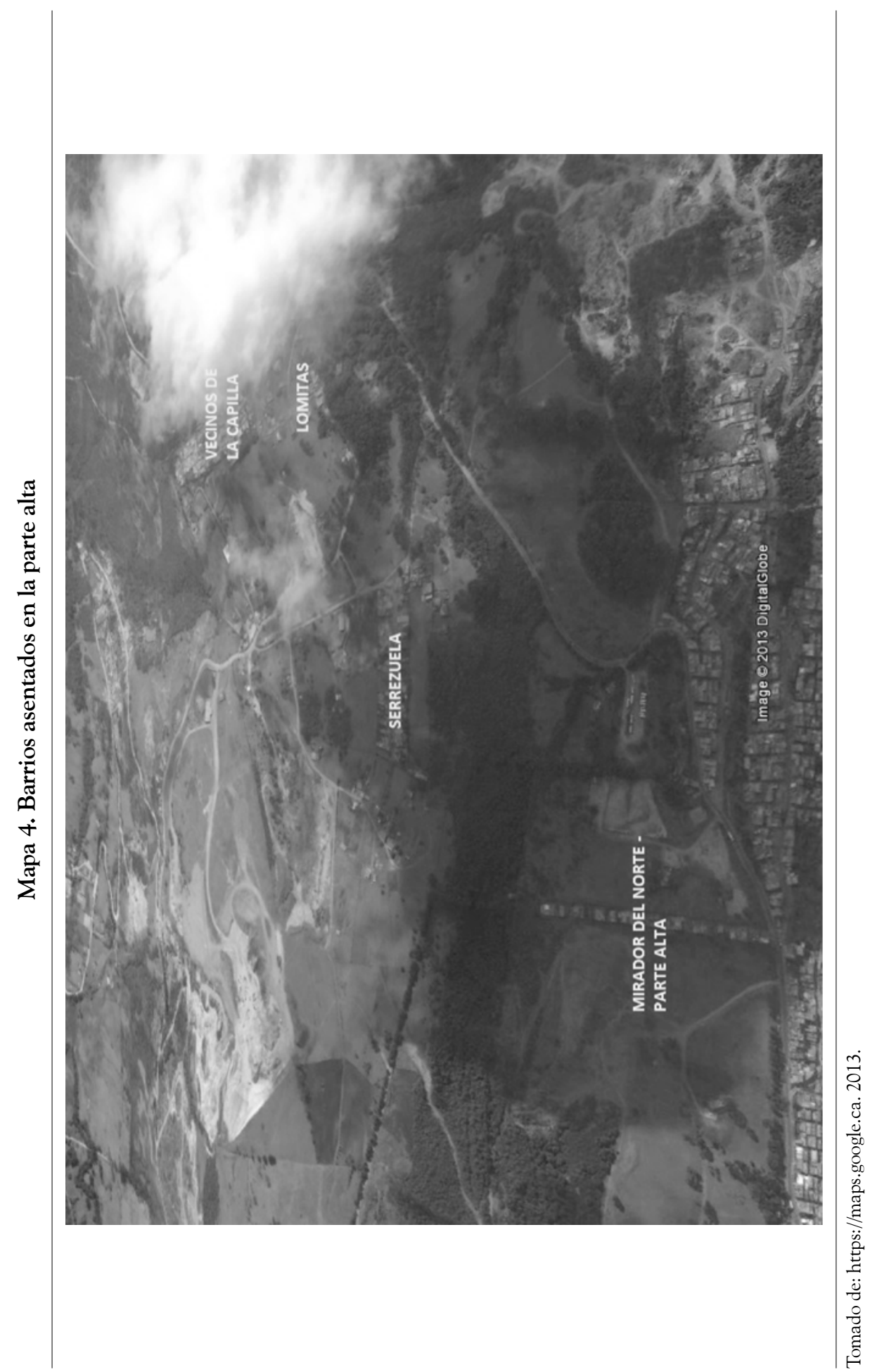


Como anteriormente se señaló, los barrios asentados en la parte alta carecen de una imagen clara que permita diferenciarlos y observar su composición territorial. Los barrios en mención son: Altos de Serrezuela, Lomitas y Vecinos de la Capilla. Basta decir que sobre esta área de la ciudad existe una indefinición fronteriza ya que algunos habitantes de estos barrios se encuentran en el municipio de La Calera y otros en Bogotá. 


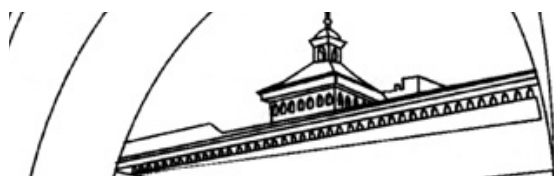




\title{
Entre la fragilidad y la vigencia. Una reflexión sobre la comunidad. Caso El Codito
}

\author{
Mónica Mendoza Molina*
}

* Socióloga de la Universidad Nacional de Colombia. Actualmente se desempeña como coordinadora de investigación social del Instituto Rosarista de Acción Social Rafael Arenas Ángel —Seres— de la Universidad del Rosario. Correo electrónico: monica.mendoza@urosario.edu.co. 
Es en verdad evidente que a pesar de un alejamiento posterior los Hobbits son parientes nuestros: están más cerca de nosotros que los Elfos y aun que los mismos Enanos. Antiguamente hablaban las lenguas de los Hombres, adaptadas a su propia modalidad, y tenían casi las mismas preferencias y aversiones que los Hombres. Mas ahora es imposible descubrir en qué consiste nuestra relación con ellos. J.R.R Tolkien, El señor de los anillos.

\section{Introducción}

El presente texto es uno de los resultados construidos con base a un ejercicio realizado por el equipo interdisciplinario de estudios en desarrollo local de la Universidad del Rosario, en el sector El Codito, de la localidad de Usaquén en Bogotá. El trabajo de la Universidad en este territorio se remonta al año 2007 y desde allí se han adelantado acciones concretas, proyectos y trabajos conjuntos con la comunidad que, en algunos casos, se han materializado en textos académicos (ver Luna, E., 2010, pp. 109-139 y Guevara, J. \& Mendoza, M., 2011).

La información aquí contenida, se enmarca en el interés del equipo interdisciplinario y de algunos sectores de la población de El Codito, por entender las formas que propician o dificultan la construcción de comunidad en el sector, así como la función que desempeña el territorio en esta labor.

Inicialmente, se realiza un recorrido por la evolución del término 'comunidad', a la luz de algunos teóricos de la sociología, que plantean características generales del término, controversias en torno al mismo y binomios que aún guardan vigencia en algunos ámbitos, tales como individuosociedad o comunidad-sociedad. Las características observadas en campo serán contrastadas con estos planteamientos y con la percepción que los mismos pobladores tienen del lugar que habitan y de las relaciones sociales que los definen. Posteriormente, se aborda el concepto de territorio, entendido como construcción social y referente simbólico, más que como espacio físico, para comprender las dinámicas de los pobladores frente a los diferentes lugares del sector, así como los significados que se le atribuye a los mismos. 
Con estas bases, se defiende la tesis de que en la actualidad no es posible encontrar comunidades tal como se definen en su concepción tradicional, más bien, es frecuente encontrar que la solidez de los lazos sociales y comunitarios, fluctúa en razón de hechos concretos o emergentes. Estos lazos, sin embargo, y los acontecimientos que los permiten, los fortalecen o los debilitan, están determinados en ocasiones por el territorio, en este caso, el sector El Codito, con sus 17 barrios.

Metodológicamente se realizó una revisión de literatura, que diera cuenta de la evolución del término 'comunidad', con el fin de contrastarla con las realidades observadas en El Codito. Posteriormente, se definió una población específica, que pudiera ofrecernos respuestas sobre los procesos que nos interesaba indagar, una población que tuviera conocimiento del territorio, de sus dinámicas de poblamiento, de los hitos, ritos y personajes determinantes del sector, de la llegada y conformación de los actores y de los cambios y transformaciones en las relaciones sociales y en el territorio.

En últimas, pretendimos remitirnos a los primeros pobladores del sector que aún permanecen allí y que son tanto testigos, como constructores y participantes activos de todos estos procesos. Estos pobladores están representados por la población de adultos mayores, con quienes además el Instituto Rosarista de Acción Social Rafael Arenas Ángel — Seres- viene realizando desde el año 2007 un proyecto concreto denominado Sabiduría de los años, que se concentra en el fortalecimiento comunitario y el desarrollo de habilidades, a través de dos acciones concretas: la alfabetización y un taller productivo. Este proyecto ha generado por un lado, fuertes lazos de confianza con la población de adultos mayores y, por otro, la consolidación de un grupo con sentido de pertenencia e identidad.

En consecuencia, la información contenida en el presente texto, se limita a las percepciones y experiencias de la población de adultos mayores del sector, sin que esto indique que no se presenten otras dinámicas y experiencias valiosas, en otros grupos etáreos u organizaciones.

Considerando que la mayoría de los participantes en el proyecto Sabiduría de los años son pobladores iniciales del sector, nos concentramos en este grupo, para construir de su mano, la relación comunidad-territorio, a través de entrevistas no dirigidas, grupos focales y talleres. La información 
allí obtenida, nos permitió dilucidar algunas formas de asociación y prácticas comunitarias que se implementaron inicialmente, que bien se mantienen o que han desaparecido, y otras que se han generado con los años, no necesariamente como iniciativa comunitaria, sino como resultado de la oferta institucional con que cuenta el sector, y que son igualmente valoradas como positivas por la población de adultos mayores.

Las actividades realizadas, también arrojaron información importante sobre la percepción que tienen los adultos mayores de otros grupos poblacionales, como los jóvenes, y sobre la importancia de ciertos lugares específicos. El presente texto pretende dar cuenta de estos resultados encontrados, procurando siempre reflejar la voz de la comunidad.

\section{¿Es posible el sueño comunitario?}

El concepto de comunidad ha sido básico para el desarrollo de la teoría sociológica a través de los tiempos. Es así, como inicialmente se le otorga un carácter tradicional, auténtico e incuestionable, otorgable sólo a los grupos sociales primarios y precapitalistas, que se recuerdan con cierta melancolía y añoranza, para posteriormente adquirir una connotación esquiva, en la cual "Es difícil precisar si se trata de un concepto, de un tipo ideal, de una descripción socio-histórica, de un ideal regulativo, de un proyecto político, del fundamento último de todo análisis sociológico" (Bialakowsky, 2010, p. 4).

Partiendo de esta evolución del término y de la diversidad de significantes que se le pueden llegar a otorgar, nos propusimos identificar formas de construcción de comunidad, o de comunidades, en el territorio específico denominado sector El Codito, en caso de que estas efectivamente se presenten.

De acuerdo a la teoría sociológica clásica, la comunidad sólo se puede definir en contraposición a su sucesora natural la sociedad, que aparece como fin inevitable de cualquier proceso de desarrollo. Dentro de esta lógica, se suele ligar el surgimiento de la sociedad, con la formación de las ciudades, la definición del Estado y las formas de producción capitalista. Actualmente, ambos términos, tanto comunidad como sociedad, son sus- 
ceptibles de revisión y se cuestiona incluso la posibilidad de su existencia en un mundo globalizado y cambiante como en el que vivimos, en donde incluso los límites y potestades del Estado son difusos. Pese a esto, nos acogemos a la premisa de que en la actualidad "La indagación por la comunidad es, al menos inicialmente, una pregunta por el lazo social, es decir, por las formas de relación social —existentes, pasadas, imaginadas, ponderadas, supuestas-y sus maneras de integración” (Bialakowsky, 2010, p. 11).

Concebir una comunidad como la descrita por los clásicos es, si no un imposible, sí una condición en extremo improbable, que retaría todos los determinantes del mundo actual, caracterizado por el individualismo, el fácil acceso a la información y la desterritorialización, entre otros factores. No quiere decir, sin embargo, que no haya iniciativas legítimas y dignas de analizar; por ejemplo, las comunidades que se consolidan en torno a un hecho histórico muy fuerte y determinante; las comunidades de paz; las comunidades que se consolidan por iniciativa y convicción de sus miembros; las ecoaldeas; las comunidades que giran en torno a la figura de un líder; o las tradicionales que perviven, pese a todos los impases de la modernidad y la posmodernidad. Estos y otros casos, representan en justa medida lo que actualmente se podría considerar "comunidad", no obstante, el término se emplea sin discriminación para denotar cientos de fenómenos y sucesos sociales.

En su concepción clásica, la comunidad fue definida en términos de tradición, cohesión social, solidaridad, territorio y naturalidad, es así, como bajo diversas etiquetas los autores clásicos otorgan características particulares a la comunidad, que se oponen radicalmente a las características otorgadas a la sociedad. A grosso modo dichos planteamientos se pueden esquematizar como se muestra en la tabla 1:

Tal vez fue Tonnies el primero en establecer esta dicotomía entre comunidad y sociedad, que se mantendría latente en el desarrollo de teorías subsiguientes, "La comunidad no solamente aparece primero que la sociedad, sino que ella es primera, no sólo más antigua que la sociedad, sino anterior a toda distinción entre formas de vida en común" (Álvaro, 2010, p. 12). 
Tabla 1. Planteamientos clásicos de comunidad

\begin{tabular}{|c|c|c|}
\hline Autor & Comunidad & Sociedad \\
\hline $\begin{array}{l}\text { Ferdinand } \\
\text { Tonnies }\end{array}$ & $\begin{array}{l}\text { - Vida en común duradera y au- } \\
\text { - téntica } \\
\text { - Organismo vivo } \\
\text { - Lo antiguo } \\
\text { - Voluntad esencial y natural }\end{array}$ & $\begin{array}{l}\text { - Artefacto mecánico, pasajero y } \\
\text { aparente } \\
\text { - Lo nuevo } \\
\text { - Voluntad racional o reflexiva }\end{array}$ \\
\hline $\begin{array}{l}\text { Max } \\
\text { Weber }\end{array}$ & $\begin{array}{l}\text { - Acción tradicional } \\
\text { - Sentimiento subjetivo de perte- } \\
\text { nencia común } \\
\text { - Natural y auténtica }\end{array}$ & $\begin{array}{l}\text { - Acción racional con arreglo a fines } \\
\text { - Acción racional con arreglo a va- } \\
\text { lores } \\
\text { - Burocracia } \\
\text { - Construida y manipulada }\end{array}$ \\
\hline $\begin{array}{l}\text { Emile } \\
\text { Durkheim }\end{array}$ & $\begin{array}{l}\text { - Solidaridad mecánica por simi- } \\
\text { litud } \\
\text { - Lazos profundos y continuos }\end{array}$ & $\begin{array}{l}\text { - Solidaridad orgánica por diferencias } \\
\text { - Basada en la división social del tra- } \\
\text { bajo especializada }\end{array}$ \\
\hline $\begin{array}{l}\text { Georg } \\
\text { Simmel }\end{array}$ & $\begin{array}{l}\text { - Vínculos naturales de adscripción } \\
\text { - Lo antiguo }\end{array}$ & $\begin{array}{l}\text { - Aislamiento de la personalidad } \\
\text { - Libertad individual }\end{array}$ \\
\hline
\end{tabular}

Fuente: elaboración propia

Desde este punto de vista, cualquier manifestación actual de grupos sociales específicos, que se unan en torno a situaciones o características particulares, no será más, que una mutación o un "mal sustituto" de las comunidades naturales primarias o de origen.

De acuerdo a la concepción de Tonnies, la comunidad implica un entendimiento tácito entre sus integrantes, por lo tanto, no es necesario consensuar o negociar y no hay lugar a desacuerdos o a críticas. Esta condición inicial genera muchos cuestionamientos, pues va en contravía a la concepción moderna de hacer política, que implica la discusión, el consenso, el escuchar la diferencia y el debate. Igualmente, choca con la concepción de sujeto social, aquel que debe ser contestatario frente a los modelos que se le imponen y cuyo deber es reivindicar diferentes formas de ver y hacer el mundo, en el marco de la diversidad. Como resultado, esta característica original otorgada a la comunidad, no encuentra actualmente ni vigencia, ni legitimidad.

Por otro lado, el hecho de que todos los individuos estén de acuerdo con una verdad que se les impone, como un todo incuestionable, se ve cla- 
ramente amenazado, si no imposibilitado, por las diferentes formas de interacción social que ofrece la vida moderna; prácticamente, en la actualidad no hay un grupo social totalmente aislado e incomunicado con el exterior. Así pues, la posibilidad de conocer diversos escenarios y formas de concepción del mundo, obliga a que la homogeneidad inicial que caracterizaba a los miembros de una comunidad, desparezca y dé origen a la diversidad de pensamientos, valores, convicciones y creencias. El aislamiento y la sostenibilidad de una comunidad dependerán entonces de un elevado grado de coerción, vigilancia y control.

Así, dentro de la concepción clásica, encontramos que el individuo desaparece para fundirse en un ente único y soberano: la com-unidad. No hay diferenciación, ni especialización entre sus miembros, todos hacen parte de un mismo cuerpo y se acogen a sus designios y normas preestablecidas. Así, la comunidad construye y determina su identidad, pero la construcción de identidad personal, es algo que solo será viable habiéndola superado.

Por su parte, Weber realiza su análisis partiendo de la definición de acción social, aquella que tiene un sentido y se orienta por las acciones de los otros. Toda acción social se define en términos de la propia cultura y se determina por sus preceptos; así, en la comunidad, las acciones estarán orientadas por la tradición, es decir, por las creencias cotidianas que se han legitimado y reproducido a través de los tiempos, mientras que en la sociedad, se añade a la acción social un componente de racionalidad, que puede estar sujeto a fines o a valores. Cuando la racionalidad está sujeta a fines, los sujetos actuarán en pro de los objetivos que pretenden alcanzar, y cuando está sujeta a valores, actuarán de acuerdo a sus convicciones consideradas verdaderas (Weber, 1994, pp. 6-7).

Tanto en el caso de la comunidad como en el de la sociedad, Weber reconoce la consolidación de distintos tipos de dominación y define a esta última, como la probabilidad de encontrar obediencia dentro de un grupo determinado, para mandatos específicos (Weber, 1994, p. 43). Los tipos de dominación legítima son: tradicional, basada en la creencia de la santidad de las tradiciones y en la legitimidad de las autoridades instauradas por ella; racional, basada en la creencia en la legalidad de las ordenaciones estatuidas; y carismática, basada en la creencia en una persona en particular, que 
ha demostrado heroísmo, ejemplaridad o santidad, en palabras de Weber, en un líder carismático. De acuerdo al análisis realizado, se defiende la idea de que en el caso específico de El Codito, la dominación legítima puede ser de tipo racional o en algunos casos, de tipo carismático. Esto se infiere por la adherencia a los mecanismos políticos instaurados en Colombia ${ }^{1}$ y por la importancia que se otorga a algunos personajes en particular, por lo general, ligados al ámbito político, como veremos posteriormente.

La diferenciación entre comunidad y sociedad, está representada en Durkheim por la división social del trabajo; afirmando, que es precisamente el trabajo el que determina las formas de interacción social. Este análisis se elabora en torno al concepto de solidaridad social, entendida como un fenómeno completamente moral, que se puede presentar de diferentes formas y que determina los niveles de cohesión social (Durkheim, 1995, p. 53).

En efecto, allí donde la solidaridad social existe, a pesar de su carácter inmaterial, no permanece en estado de pura potencia, sino que manifiesta su presencia mediante efectos sensibles. Allí donde es fuerte, inclina de manera firme a los hombres unos hacia otros, les pone frecuentemente en contacto, multiplica las ocasiones que tienen de encontrarse en relación (Durkheim, 1995, p. 53).

En este sentido, es precisamente la solidaridad la que potencia una comunidad y, en general, la que la posibilita. De acuerdo a lo observado en campo y a las percepciones de los pobladores de El Codito, nos atrevemos a afirmar que esta premisa sigue vigente y que se consolida como componente fundamental de cualquier comunidad. Respecto a la solidaridad también afirma Durkheim que “(...) Cuanto más solidarios son los miembros de una sociedad, más relaciones diversas sostienen, bien unos con otros, bien con el grupo colectivamente tomado, pues, si sus encuentros fueran esca-

1 Durante el año 2010, se realizó un diagnóstico poblacional en el sector, que arrojó los siguientes resultados en materia de participación electoral: el 94\% de la población votó para elegir presidente, el $62 \%$ para elegir alcalde, el 44\% para elegir concejales, el 43\% para elegir senadores, el $43 \%$ para elegir representantes, el 33\% para elegir ediles, el 30\% para elegir Junta de Acción Comunal y el 23\% para elegir Parlamento Andino (Equipo-Interdisciplinario-EstudiosDesarrollo-Local, 2010). Sin embargo, llama la atención, que la participación para elección de autoridades locales es mucho más baja que para autoridades distritales y nacionales. 
sos, no dependerían unos de otros más que de una manera intermitente y débil" (1995, p. 53)

Durkheim distingue dos tipos de solidaridad, la solidaridad mecánica o por semejanzas y la solidaridad debida a la división del trabajo u orgánica. El primero, corresponde al derecho represivo, es decir, aquel cuya ruptura constituye delito, reconociendo que todo crimen cumple con ciertas características habituales como: herir sentimientos comunes a todos los "individuos normales" de la sociedad y herir estados fuertes y definidos de la conciencia colectiva, por lo tanto, las reglas del derecho penal, expresan las semejanzas sociales más esenciales y corresponden a la solidaridad derivada de las semejanzas (ibídem, p. 65). También afirma que:

Existe una solidaridad social que procede de que un cierto número de estados de conciencia, son comunes a todos los miembros de la misma sociedad. Es la que, de una manera material, representa el derecho represivo, al menos en lo que tiene de esencial. La parte que ocupa en la integración general de la sociedad depende, evidentemente, de la extensión mayor o menor de la vida social que abarque y reglamente la conciencia común. Cuanto más relaciones diversas haya en las que esta última haga sentir su acción, más lazos crea también que unan el individuo al grupo; y más, por consiguiente, deriva la cohesión social de ésta causa, y lleva su marca (ibídem, 1995, p. 83).

El segundo tipo es el de la solidaridad orgánica, que aumenta con la actividad funcional de los organismos y que poco a poco le va restando terreno a la solidaridad mecánica. A ella corresponde el derecho cooperativo y pertenece más al ámbito individual, puesto que en ella, la conciencia colectiva se ha visto debilitada y deslegitimada. Así, afirma Durkheim, que los lazos sociales que se derivan de la división social del trabajo, son más numerosos y más fuertes que los que se derivan de las semejanzas sociales. Este tipo de solidaridad, será preponderante entonces en sociedades avanzadas.

Como común denominador en estas concepciones clásicas de comunidad, encontramos entonces la necesidad de algún tipo de dominación, para garantizar la cohesión y el funcionamiento como grupo social. 
Con la desaparición de las comunidades de origen, debida inicialmente a los procesos de industrialización y urbanización, la dicotomía entre comunidad y sociedad desaparece para dar paso a la nueva forma individuosociedad. Dentro de esta lógica, Simmel establece su planteamiento, enfatizando en el carácter individualista de la sociedad y en la tensión existente entre esta y el individuo como tal. Para Simmel,

Lo más antiguo es lo más simple menos especializado y menos articulado, resulta que no sólo en función de esto es accesible a una generalidad mayor, sino que ya lo es también puramente por ser el más antiguo, o sea que es el que con mayor seguridad se ha transmitido exterior e interiormente a cada individuo y por ello resulta más obviamente legítimo y depositario de valor (Simmel, 2002, p. 63).

La nueva sociedad se caracterizará entonces por su especialidad, su complejidad y su atemporalidad, de allí que la pérdida de la comunidad represente el logro de la libertad, toda vez que al desligarse de un grupo fuertemente cohesionado, mediado por la tradición, las creencias, la memoria colectiva y la aceptación sin cuestionamientos, el individuo adquiere la posibilidad de conocer otras realidades, de movilizarse a su antojo y sobre todo de diferenciarse de los demás. La diferenciación de un individuo de los demás, pasará a ser mucho más interesante que cualquier similitud con ellos, por ello, la diferenciación enarbola la bandera de la liberación. Para Simmel, sin embargo, esta pretendida liberación se puede entender también como algo problemático, al respecto afirma que "Los más profundos problemas de la vida moderna manan de la pretensión del individuo de conservar la autonomía y peculiaridad de su existencia frente a la prepotencia de la sociedad, de lo históricamente heredado, de la cultura externa y de la técnica de la vida" (ibídem, 2001, p. 107).

Así, la ruptura de la comunidad tradicional fue fundamental para el surgimiento del individuo, al permitir la capacidad de elegir, característica inseparable, no sólo del concepto de libertad sino también del de dignidad humana. 
Para los teóricos contemporáneos, la tensión entre comunidad y sociedad, deja de ser centro de atención, para en su lugar ahondar en las diferentes formas sociales propias de las sociedades modernas, o en las diferencias existentes entre estas últimas y las sociedades que las precedieron o que mantienen realidades consideradas premodernas.

Habermas, por ejemplo, ahonda en esta división entre las sociedades modernas y premodernas, para él "el mundo de la vida" representa el sentido compartido por un grupo determinado, que en sociedades premodernas estaba subordinado a lo sacro, por lo que no era cuestionable, y en las modernas se encuentra en constante revisión. Las "comunidades de comunicación" son propias de las sociedades modernas, que no son otra cosa que subculturas que desarrollan identidad personal y colectiva y que promueven estilos de vida alternativos y diversos (Bialakowsky, 2010, p. 14). Por su parte, Giddens habla de "comunidades reflexivas" caracterizadas por ser de fuerte intensidad, pero esporádicas y en permanente revisión, en las que no hay otro vehículo que permita entretejer las relaciones sociales, más allá de la reflexividad (ibídem, p. 23).

Bauman plantea que, en general, se tiene el sentimiento de que la comunidad es siempre algo bueno, que garantiza seguridad para sus miembros, pero que, sin embargo, representa la pérdida de libertad.

La seguridad y la libertad son dos valores igualmente preciosos y codiciados que podrían estar mejor o peor equilibrados, pero que difícilmente se reconciliarán nunca de manera plena y sin fricción (Bauman, 2003, p. 11).

En torno a esta dicotomía gira su planteamiento, en la búsqueda constante de comunidad, con posibilidades de vinculación a la misma, solo en la medida en que las libertades personales no se vean amenazadas o restringidas. De esta manera, los componentes de flexibilidad y temporalidad juegan un rol fundamental, ya que permiten, por un lado, la posibilidad de pertenecer a varias comunidades a la vez y, por otro, la posibilidad de renunciar a las mismas cuando así se desee. Se introduce entonces, el concepto de satisfacción que hace referencia a la pertenencia a una comunidad por elección y conveniencia, y en el cual, muy contrariamente a la idea original de comunidad, prima el interés particular sobre el general. Este fenómeno tiene múltiples respuestas y Bauman resalta el hecho de que las "obligacio- 
nes fraternales", tan características de la comunidad, son poco llamativas para los individuos que no solo se quieren diferenciar de "los otros", sino que además quieren ser reconocidos; el hecho de compartir beneficios y victorias, con quienes pueden no tener tantos méritos, no resulta apetecible.

Las nuevas dinámicas sociales han llevado a que en la actualidad se hable de "comunidades desechables", es decir, aquellas que se pueden consolidar en torno a un acontecimiento único, y que, por lo tanto, son de naturaleza superficial y episódica de los vínculos, aquellas en las que no hay compromisos a largo plazo, responsabilidades éticas, ni consecuencias. Muchas de estas características se han presentado en el sector El Codito, tal como lo expondremos más adelante.

La pérdida de la comunidad original, sin embargo, representó y tal vez siga representando, una necesidad de "recomunización" que ha adquirido diversas formas, desde los barrios obreros resultantes de la Revolución Industrial, hasta las nuevas comunidades basadas en afinidades, convicciones o intereses, que la mayoría de las veces tienen un carácter transitorio y flexible, es decir, que permiten el ingreso o salida de sus miembros al antojo de cada cual. Si los miembros dejan de encontrar en su grupo la satisfacción de sus necesidades particulares, fácilmente pueden abandonarlo y buscar otro nuevo que cumpla con sus expectativas.

Este planteamiento, que incluye aspectos de suma importancia como la temporalidad y la simultaneidad, y que se adapta más a las condiciones y modos de vida actuales, no obstante, no es del todo nuevo, ya Durkheim hacía referencia a la posibilidad de pertenecer a una comunidad en relación con un solo aspecto de la vida social, cuando hablaba de los "grupos profesionales", que tenían un carácter parcial, reconociendo que no necesariamente la comunidad se consolida como un "todo", sino que puede permear solo algunos aspectos de la vida de los individuos.

En estos términos, tal vez sea posible referirse a la población de El Codito como comunidad, o como comunidades parciales que se consolidan en torno a diversos factores, como edad, gustos, identidad barrial, intereses, grado de participación, apropiación de espacios y actividades conjuntas, entre otros, más no como comunidad totalizada. Esto se demuestra desde el punto de vista de las prácticas, de la relación de este territorio específico 
con el resto de la ciudad y más aún de la percepción de sus propios habitantes. De cualquier forma, coincidimos con Bauman cuando afirma que "El de comunidad es hoy otro nombre para referirse al paraíso perdido al que deseamos con todas nuestras fuerzas volver, por lo que buscamos febrilmente los caminos que puedan llevarnos allî” (Bauman, 2003, p. 9).

Así, el término "comunidad" tendrá una valoración positiva, que evoca fraternidad, unión y cohesión, y, de este modo, será motivo de evocación y deseo. En este sentido y para concluir con las concepciones de comunidad, podemos afirmar con Touraine que "A finales del siglo pasado, en plena industrialización del mundo occidental, los sociólogos nos enseñaron que pasábamos de la comunidad, encerrada en su identidad global, a la sociedad cuyas funciones se diferenciaban y racionalizaban. La evolución que hoy vivimos es casi la inversa" (Touraine, 1997, p. 12 ).

De esta manera, observamos nuevas necesidades de asociación, de identidad y de homogenización, que se hacen presentes en todos los ámbitos de la vida actual y que, por supuesto, no escapan a las lógicas particulares, de los habitantes de El Codito.

\section{Indicios y sentires de comunidad en El Codito}

El análisis de las particularidades de El Codito, consolidado como un espacio determinado y definido como "localidad" dentro de la lógica de división administrativa de Bogotá, se realizó con base a tres características propias de las comunidades de origen, como son: la homogeneidad de sus miembros, la diferenciación respecto de otros grupos sociales y la autosuficiencia.

Respecto a la homogeneidad, en este espacio confluyen diversidad de actores que distan mucho de ser similares entre sí, y que más bien se insertan en determinados subgrupos, definidos bien sea por afinidad, identidad, necesidad o por roles adjudicados o adquiridos. Dichos actores pueden hacer presencia permanente o no en el territorio, pero lo cierto es que lo afectan de manera directa o indirecta.

A partir del trabajo realizado en campo y de la presencia por más de tres años en el sector, hemos identificado algunos actores, que pueden ser 
endógenos o exógenos y que se clasifican según temática, grupo poblacional o carácter político. Dichos actores, que influyen de diversas maneras en los demás actores y que establecen variadas relaciones con el entorno y los otros se presentan en la tabla 2.

Tabla 2. Actores del sector El Codito

\begin{tabular}{|c|c|}
\hline Tipo de organización & Actores \\
\hline Centros educativos & $\begin{array}{l}\text { Colegio Don Bosco III, colegio Nuevo Horizonte, colegio Frie- } \\
\text { drich Naumann, colegio privado Los cerros y jardín infantil } \\
\text { Obra Suiza }\end{array}$ \\
\hline $\begin{array}{l}\text { Grupos de adulto } \\
\text { mayor }\end{array}$ & $\begin{array}{l}\text { Crear, Recordar es vivir, Sabiduría de los años, hogar San Ga- } \\
\text { briel, agricultura urbana Horizontes, Buenavista }\end{array}$ \\
\hline Asociaciones & $\begin{array}{l}\text { El Codito, Buenavista, Estrellita, Chaparral-Estrellita Horizon- } \\
\text { te, Brisas de Buenavista, Chaparral-Llanurita, Nuevo Progreso, } \\
\text { Asocerros }\end{array}$ \\
\hline $\begin{array}{l}\text { Medios de comunica- } \\
\text { ción }\end{array}$ & TV Unidos, Medios en común, Omega 7 \\
\hline $\begin{array}{l}\text { Juntas de Acción } \\
\text { Comunal }\end{array}$ & $\begin{array}{l}\text { Llanurita, Buenavista sectores I y II, La Franja, Las Mercedes } \\
\text { Norte, El Codito, Serrezuela, Mirador Norte parte alta, Balco- } \\
\text { nes de Vista Hermosa, Nuevo Horizontes, Chaparral, Mirador } \\
\text { Norte, Lomitas, Estrellita Norte, Horizontes }\end{array}$ \\
\hline Comités & Comité de vecinos Capilla \\
\hline Grupos de jóvenes & $\begin{array}{l}\text { Beat Down Entertaiment-Plasma, Gheto Estilo, Huellas, } \\
\text { Conjurarte, Puertas del Arte, Kalisaya, Agroecología, Mundo } \\
\text { Joven, Vínculos, Voces sin Atajos }\end{array}$ \\
\hline Instituciones distritales & UPA Codito, UBA Buenavista, Hospital de Usaquén \\
\hline Ediles & $\begin{array}{l}\text { Patricia Jerez, Liliana de Diago (ex edil), Luis Villamil, Ómar } \\
\text { Cárdenas (ex edil) }\end{array}$ \\
\hline Grupos de mujeres & Madres FAMI, Red de Mujeres \\
\hline Otras organizaciones & $\begin{array}{l}\text { Provivienda, Copevisa, Boys Scouts (dos grupos), Danza folcló- } \\
\text { rica Usaca, Universidad del Rosario }\end{array}$ \\
\hline
\end{tabular}

Fuente: Elaboración propia, basada en información construida por el equipo interdisciplinario de Estudios en Desarrollo Local.

Así, se podría afirmar que la necesidad de homogenización, se materializa básicamente en términos de edad — grupos de adultos mayores y 
grupos de jóvenes—, intereses políticos — juntas comunales, asociaciones, comités y personajes políticos—, grupos poblacionales específicos — mujeres-y sectores particulares —educación, cultura, vivienda y comunicación-. Los actores externos, habitualmente, están representados por las instituciones distritales o estatales, que, por su naturaleza, deben propender por la oferta de servicios y la garantía de derechos, y por organizaciones no gubernamentales o privadas, que igualmente brindan servicios.

En materia de diferenciación, las condiciones de la población de El Codito, así como las dinámicas de poblamiento del territorio, no son únicas o propias, sino que se asimilan en varios aspectos, a las condiciones de otros barrios ubicados en diferentes sectores de la ciudad. Al respecto, nos acogemos al planteamiento de Bourdieu, quien realiza un análisis social desde una nueva perspectiva, afirmando que las dicotomías de individuo-sociedad, individuo-colectivo u objetivo-subjetivo, planteadas anteriormente como verdad irrefutable, carecen de sentido aunque se hayan impuesto de manera tan contundente en el ámbito de las ciencias sociales (Bourdieu, 1997, p. 8 ). Él en cambio, propone una filosofía de la acción o relacional (basada en las relaciones) y disposicional, enmarcada en los conceptos de habitus, campo y capital.

Así, trasciende el concepto de sociedad, lo que da lugar al concepto de "espacio social", que se consolida como estructura de diferencia y se determina por la distribución de las formas de poder; estas últimas varían según los lugares y los momentos, es decir superan los límites del territorio y el tiempo. Esta teoría resulta muy interesante para el caso que nos ocupa, pues nos permite replantear los conceptos de comunidad y territorio, en donde el primero desparece para dar lugar a las asociaciones por afinidad y cercanía en el espacio social; y el segundo pierde el interés desde el punto de vista físico, dado que el espacio social es algo intangible e invisible.

Analizar las condiciones de El Codito a la luz de este planteamiento, resulta, a nuestro modo de ver, muy apropiado, pues consideramos que las prácticas y representaciones de los agentes, están más determinadas por aficiones y afinidades, que por factores relativos al territorio, al pasado común o al grado de cohesión social. Un ejemplo claro, es el de los jóvenes quienes se agrupan en torno al hip-hop, tanto en El Codito como en otros sectores 
de la ciudad, con los que se comparten características socio-económicas similares, en este caso, el hip-hop expresa una manera particular de pensar, de sentir y de ubicarse en el campo social, que se consolida como principio de diferenciación respecto a otras posiciones.

En cuanto a la autosuficiencia, no se puede afirmar que la población de El Codito tenga esta cualidad, muy por el contrario, sus pobladores deben buscar ofertas laborales, educativas, alimenticias y de salud por fuera del sector, vinculándose a los sistemas de seguridad social y educativo del Distrito, así como a los programas oficiales y extra oficiales que ofrecen las distintas entidades. Sin embargo, es importante mencionar experiencias como las huertas comunitarias, que permiten el autoconsumo de los productos cultivados y en ocasiones su comercialización, o las iniciativas productivas, como el taller de papelería y tarjetería de los adultos mayores, que genera beneficios a sus participantes.

Entonces, se puede concluir que como grupo social, la población de El Codito no se puede catalogar como comunidad en el sentido tradicional del término, dado que no cumple con sus principales virtudes. Se hace necesaria entonces, la identificación de otros factores que pueden facilitar o dificultar las prácticas comunitarias, y que dan indicios de la consolidación y fortalecimiento de los lazos sociales presentes en la población. Para tal fin, en esta primera parte del texto, nos centramos en el grupo poblacional de adultos mayores, considerando que desde su condición de fundadores de los barrios, pueden ofrecer una visión amplia del territorio y de la evolución de los procesos comunitarios.

En procura de esta identificación, y gracias a la participación libre, consciente e informada de los adultos mayores, en las diferentes acciones propuestas en la investigación, encontramos que esta población siente que vive en una comunidad, aunque no se logra poner de acuerdo para definir si había una mayor cohesión social al momento de la fundación de los barrios o en la actualidad. De esta manera, encontramos que el término comunidad se entiende como:

- Ser unido y asistir a reuniones

- Vivir acompañado 
- Estar juntos frente a determinadas coyunturas

- Acompañar y apoyar a los vecinos

- Identificar y elegir a las personas que están pendientes del barrio

- Participar de las reuniones de la Junta de Acción Comunal

- Difundir información importante a los vecinos

- Participar de las actividades que ofertan las instituciones

- Tener cariño hacia las personas

- Cuidarse unos a otros

- Mandar

- Estar pendientes de las cosas y vigilar

- Realizar actividades conjuntas como brigadas de aseo

- Comprenderse

- Consolidar una asociación de personas que se ayudan libremente

- El número de personas que habita el territorio ${ }^{2}$

De este modo, se le atribuyen al término valoraciones eminentemente positivas, aunque llama la atención, que pocos de los participantes reconocen la importancia de la organización y la estructuración de agendas, encaminadas al logro de objetivos o metas concretas. Se reconoce en cambio, la necesidad de buscar líderes, de establecer normas y de acogerse a ellas, en términos weberianos, podríamos afirmar entonces, que se otorga legitimidad a ciertas formas de dominación.

Al hablar de comunidad, en el caso particular de El Codito, los entrevistados hacen una diferenciación clara entre propietarios y arrendatarios, señalando a estos últimos de protagonizar escenas que perturban la tranquilidad del sector, a este respecto, también se afirma que es difícil consolidar comunidad, cuando la población es tan flotante. Otro reconocimiento importante es que la "comunidad" toma forma en situaciones coyunturales, es decir, tiene un carácter transitorio, en el cual, el ámbito de lo público se

2 Varios adultos mayores concuerdan en que antes en el sector no había comunidad, porque no había casi gente, pero afirman que actualmente sí la hay, porque es muy poblado. Esto indica que la noción de comunidad que predomina, no trasciende del número de personas que comparten un mismo territorio, sin ahondar en aspectos culturales o tradicionales, de convicción, de preferencia o de pasado común. 
fortalece con situaciones específicas, que al terminar, generan un retorno a la prevalencia del ámbito familiar, privado.

Al agrupar las opiniones de las participantes, se identificaron las siguientes categorías como fundamentales para la construcción y sostenibilidad de una comunidad: unión, organización, participación, cuidado y pertenencia. Sumado a estos factores, la población de adultos mayores otorga un reconocimiento a las JAC por su labor, por facilitar los trabajos comunitarios y por convocar, por diversos medios, a los habitantes del barrio, para la realización de jornadas comunitarias. Igualmente, se reconoce la importancia de la oferta institucional, en lo que se refiere a actividades, talleres y jornadas, para la integración y participación de la población de adultos mayores.

En las entrevistas se reseñan algunas prácticas comunitarias, que se realizaban inicialmente en el sector, pero que se fueron perdiendo con el paso del tiempo, entre ellas se encuentran:

- El cuidado de los hijos por parte de los vecinos, cuando los padres tenían que trabajar.

- El establecimiento de turnos entre las madres de familia, para el cuidado y alimentación de los niños en los jardines infantiles.

- La construcción en conjunto de vías, salones comunales o escaleras.

- La realización de actividades lúdicas (rifas, bazares, etcétera) para la recolección de fondos de uso común.

- El establecimiento de turnos de vigilancia en las noches.

- La carga de material para proyectos comunes.

La construcción de las casas, sin embargo, nunca se constituyó como trabajo comunitario, por el contrario, cada familia se debía hacer cargo de su vivienda, a excepción de los barrios Chaparral y Buenavista, cuya creación estuvo enmarcada en los procesos de Provivienda, que implicaban la construcción comunitaria de cada una de las viviendas familiares.

Con la información obtenida en las entrevistas efectuadas a los adultos mayores, se vislumbraron imaginarios propios de este grupo etáreo. Así, 
por ejemplo, con contadas excepciones, se asocia a los jóvenes con la rumba, el trago, la marihuana, las drogas, la calle, la inseguridad y los hurtos; igualmente, se atribuyen características a las mujeres y a los hombres, para explicar la baja participación de estos últimos en los talleres y actividades que ofrecen las distintas instituciones en el sector para ellos. Así, la mujer se reconoce como más comunicativa, comunitaria, servicial, trabajadora y responsable y el hombre como "mandón", orgulloso y desinteresado. Según las respuestas, las mujeres se apropian de los espacios comunitarios y se ocupan de las labores de la casa, mientras que los hombres ocupan su tiempo libre jugando naipe o tejo e ingiriendo bebidas alcohólicas en cantinas o tiendas. Si bien, los adultos mayores hombres tienen una muy baja participación en dichas actividades, tienen una participación más representativa en otros espacios más tradicionales y políticos, como las Juntas de Acción Comunal, las reuniones para temas electorales o para la toma de decisiones. Esto se puede deber a que posiblemente las mujeres encuentren en los espacios de los talleres, escenarios de participación que le fueron negados anteriormente, por esto, en ocasiones afirman que comenzaron a vivir ya de viejas y que agradecen enormemente las actividades y los momentos de encuentro con sus compañeras.

\section{Algunos momentos y personajes en la memoria de El Codito}

Respecto a los grandes hitos del sector, con los que se identifica la comunidad, se mencionan los siguientes:

- Instalación de la tubería

- Construcción del primer supermercado de frutas y verduras

- Pavimentación de las calles

- Recolección de agua en galones en la quebrada Zarauz

- Creación de las JAC

- Instalación de servicios públicos domiciliarios 
- Llegada del Plan Pisingo ${ }^{3}$

- Construcción de las vías

- Lavado de ropa en la quebrada

- Ayudas del Club Rotario

- Construcción del jardín infantil ${ }^{4}$

- Instalación de alumbrado informal

- Llegada de las rutas de transporte público

- Oferta de programas por parte de la Universidad del Rosario y de la Alcaldía

- Donación de una moto para vigilancia

- Otorgamiento del bono del Distrito

Estos momentos importantes se pueden ubicar entonces dentro de las siguientes categorías: servicios públicos, movilidad, abastecimiento de víveres, organización comunitaria e intervención de agentes externos. Respecto a las celebraciones, festividades o eventos, es importante mencionar que no se presentan de manera autóctona en El Codito, es decir, no hay festividades propias del sector. Sin embargo, se presentan algunas prácticas como la "Semana por la paz", que si bien no nace allí, sí se ha institucionalizado desde hace algunos años, contando con la participación de diferentes sectores de la población.

Como se mencionó anteriormente, Max Weber introduce la figura del líder carismático; aquel que posee la facultad de aglomerar, movilizar y cohesionar un grupo social, en pro de intereses comunes. La figura del líder ha sido clave para el entendimiento de los procesos comunitarios en el sector El Codito, ya que este grupo social se siente comunidad en escenarios y coyunturas específicas, y a la luz de personajes concretos y recordados. Estos líderes, sin embargo, no han representado en todos los casos los intereses de la mayoría, sino que son también, en ocasiones, quienes detentan el poder económico, político o de la fuerza. En este caso concreto, algunos se

\footnotetext{
3 Apadrinamiento de niños y préstamos a las familias.

4 Todos los padres de familia cargaron material desde abajo y agua en galones para los niños.
} 
consolidan como dueños iniciales de la tierra, administradores de la misma, presidentes de juntas comunales o prestadores de servicios.

Como resultado del ejercicio de recopilación de información realizado en el sector, se identificaron los siguientes personajes como los más recordados dentro de la población de adultos mayores.

Presidentes de Junta de Acción Comunal: la información obtenida en las entrevistas y en los talleres, permitió establecer la cronología de los presidentes de la JAC del barrio Horizontes, de esta manera:

- Eugenio Montenegro

- Peña

- Clodomiro Simijaca

- Rafael Vela

- Salomón Conde

- Jorge Guzmán

- Hernando Palomino

- María Jesús Viejo (Chus)

Del barrio El Codito, se recuerda a Miriam Puerto como una mujer muy activa y trabajadora, en la plenaria se le reconoció como: "Luchadora. Colaboraba con su pueblo. Fue presidenta de junta, como seis años. Ella hizo mucho, mucho por el barrio. Colaboró para las casitas que eran en tela, en paroid. Así empezamos todos (...)". ${ }^{5}$

No se posee información de los otros presidentes, ni tampoco de los presidentes de otros barrios.

José Domingo Cristancho: este personaje es recordado como el propietario inicial de los terrenos que actualmente conforman el barrio Horizontes. Fue él quien vendió los lotes a los pobladores iniciales del barrio y, en general,

5 Los testimonios registrados en adelante, son apartados de las entrevistas a profundidad realizadas a los adultos mayores del sector. 
42

es percibido como un obstáculo para la consecución de las escrituras de los mismos.

Al respecto se obtuvieron los siguientes testimonios:

Le pagaba cuotas pero él se perdió, no sabíamos para donde se fue ni donde ir a pagarle. Yo le debía $\$ 6700$ y un buen día alguien me dijo que él tenía una oficina en la Avenida Jiménez con décima. Me fui con otra persona y allí le encontré en el sexto piso. Le pregunté cuanto le debía. Él dijo que $\$ 180000$. El lote se lo había comprado en $\$ 33000$. Él dijo que yo me había perdido. Dijo que por los intereses, la mora. Yo estuve pensando y le dije "sí le voy a pagar pero estoy pensando cómo hacer. Ir y conseguir quien me compre el lote, venir y pagarle a usted y coger mis chinos y bajar por donde mismo subí porque no me queda otra alternativa. Yo no tengo esa plata. Vine acá, hablé con el Presidente de la Junta, no me acuerdo bien si era Peña...

Entonces yo vine, le conté y me dijo que no solo era yo la del problema. Nos reunimos en el salón comunal, que ya existía este, y éramos 60 que teníamos el mismo problema. ¿Qué hicimos? Nos reunimos como diez y nos fuimos otra vuelta a la oficina de Cristancho y le convencimos para que viniera aquí a una reunión con nosotros. Ese día esto se llenó y llegamos a un arreglo de que yo no le pagaba los $\$ 180000$ sino $\$ 40000$. Pero había otro problema, que mi esposo ya había muerto y él ya había vendido la mitad. iDe dónde saco yo los $\$ 40000$ ? Fui donde don Marcos que era al que le habíamos vendido y le conté el problema. Dijo, hágame un favor, como yo estoy recién entrado a mi trabajo no puedo sacar ese piso, pero hable allá como cosa suya y yo le colaboro, que ya es otra voz. Pida toda la rebaja que pueda y yo le colaboro. Así fue, quedaron $\$ 45000$. Él me dio $\$ 21000$ y ya fue cuando me hicieron escritura, que salimos 25. Nos cobraban $\$ 5000$. En ese tiempo era una plata. Después que $\$ 100000$, que $\$ 200000$ Una doctora sí vino. La doctora Gladys sí nos hizo las escrituras, los primeros somos 25 y de ahí el resto a bregar a que les hicieran sus escrituras.

Esto (el barrio Horizontes) era una finca, un terreno, y nosotros compramos estos pedazos acá, y como no había nada, ni luz ni nada, el baño 
lo hacíamos por ahí por este monte. El agua, de donde sube la quebrada de la séptima donde sube la avenida para acá, a la espalda, en burro, en volqueta, a construir, a lavar, nos tocaba ir a la una, dos de la mañana, porque eso era un hervidero. Era cantidad de gente que venía de todos los lados.

Se discutió entre todas las participantes que antes del señor Cristancho había otro dueño de los terrenos. Al respecto se afirmó:

Sí claro, pero no se sabe cómo se llamaría. Tenía otra finca debajo de la séptima. Se cogió una plata, y esa plata se la quitó el banco del Estado. Hasta ese momento era todo lo que se había sabido. Por eso le quitaron la finca de abajo. Por allí para el sur, por el Chaparral. Él estuvo preso, lo encarcelaron. A mí en ese tiempo me vendieron por $\$ 27000$ el lote. Yo le estaba pagando a él las cuotas como de $\$ 2000$ pesos. Eso era poquito. Después ya vino la abogada y me dijo que le debía $\$ 70000$. Entonces fui allá y dije que no debía nada. Y gracias al señor Simijaca, que eso sí se lo agradezco. Yo venía con los papeles y le conté lo que me pasaba. Me dijo que no le pagaría ni un peso al señor Cristancho, porque ya había pagado. Ya haga su escritura. Simijaca me sacó de ese pleito y listo. Contrató a la doctora Gladys, nos reunimos acá y él fue sacando escrituras. Nos cobró $\$ 45000$ por la escritura del doctor Cristancho.

Próspero: este personaje fue recordado en algunas de las entrevistas como uno de los representantes de Provivienda, sin embargo, no fue mencionado de manera importante en la plenaria general realizada con las participantes de las entrevistas.

Juan Albarracín: recordado como patrón de obras del barrio Horizontes.

Roberto: recordado como la persona que disponía sobre la propiedad de los lotes. Al respecto se obtuvo el siguiente testimonio: 
Él era de acá de este barrio de Horizontes. Él era el que mandaba todo esto de la finca, desde debajo de la séptima hasta acá el Mirador, él cuidaba una casa grande. Con la señora Isabel, la esposa. Y después de que el doctor Cristancho le compró al dueño, no sé quién sería, entonces ya a Roberto lo dejaron allá. Un pedazo. Como cinco o seis lotes le dejaron a él. Ellos eran los que cuidaban todo esto. Se hizo cargo allá donde lo dejó don Cristancho. Ya fue cuando él echó a urbanizar el primer sector de acá, después el segundo sector de aquí para allá... Yo no lo recuerdo a él, pero sí donde vivía, la casa. La Fronterita se llamaba eso. Sí. La hija Isabel, se perdió por aquí. Era una persona muy buena gente. Cuando yo lo traté a él y a la esposa, eran muy buenas personas.

Jairo Urrego: mencionado en alguna de las entrevistas como "supervisor del barrio", no fue tan recordado en la plenaria.

Rafael Vela: presidente de Junta de Acción Comunal. "Ese, que duró aquí cuatro años, que apoyaba y anduvo y recogió para comprar los utensilios para las escobas, para los traperos, para todo eso, que por ahí estaba trabajando, yo no sé cuanto porque no viene por acá.”

José: algunas personas son recordadas por la mayoría de las participantes con mucho cariño, tal es el caso de don José, un médico de profesión que brindó sus servicios de manera especial a la comunidad. De él se dice que fue secuestrado y asesinado. "Amaneció en el apartamento amarrado con los cordones de los zapatos. No sé sabe quién ni por qué pudo hacerlo. Era una gran persona."

Carlos Arango: este personaje es recordado por ser el propietario de una de las primeras tiendas en el barrio, también se asocia con la venta de licores.

Muñoz: fue un concejal muy recordado en la comunidad, por haber gestionado varios asuntos referentes a servicios públicos. 
Domingo Rivera y Carmelita: esta pareja de esposos es recordada por ser dueña del primer restaurante del sector, una pollería.

Otros actores del sector: Giddens, observa un aspecto muy interesante relacionado con la valoración de la comunidad, ya que si bien en general se otorga a la misma un significado positivo, se reconoce que no siempre las "comunidades" tienen un buen interés, ya que pueden incluso intensificar desigualdades o consolidar poderes.

A la luz de este postulado, se puede analizar el caso de las pandillas o grupos delincuenciales juveniles que generan una identidad y códigos propios, que los diferencian de los demás y que determinan patrones de comportamiento. En el caso de El Codito, algunos de estos grupos incluso se han consolidado inicialmente en torno a familias concretas y han impuesto sus normas y afianzado sus poderes con claras delimitaciones territoriales; son reconocidos por toda la comunidad y al ser protagonistas de diversos actos considerados violentos, muchos han sido asesinados.

Algunas familias reconocidas como problemáticas, pertenecen al sector, otras en cambio, surgieron en barrios aledaños. Respecto a las primeras, la comunidad menciona: "Son bien renombrados. iAy si! (...) Siempre han sido de allá de Mirador. Ellos son del Mirador pero bajan aquí (...) Es que ellos son hartos y viven en distintos predios. Es que les han dado duro. Por pícaros. Muy vengativos. Muy buscarruidos. Y es que ellos se forman como una pandilla. Sí, pandilleros”.

Respecto a las familias problemáticas del sector y las de barrios aledaños, se dice que:

(...) Pues son pandillas como enemigas. Ellos tienen que respetar sus espacios. Los últimos que dejaron los dejaron allá en el Castillo. Ahí en el piso. Mataron a gente. Existen hace como 25 años. Pero siguen. Eran poquitas casitas. Donde había una peñita, tomaban, comían y cuando les cobraban entonces agarraban la casa a piedra. También ellos tenían

6 Los extractos presentados a continuación, hacen parte de algunas de las entrevistas realizadas para la investigación. 
miedo. Ya veían que llegaban, e inmediatamente cerraban las puertas. La situación con ellos está mejor ahora que hace unos años. Han ido muriendo muchos. Los mataron. Ya no, ya los que quedan son muy poquitos.

(...) Yo tengo un hijo que uno de esos lo apuñaló (...) Yo recogí mi chino envuelto en una sábana y me lo llevé para el (Hospital) Simón Bolívar. Y era una pluma de sangre que salía de él. Pero nosotros no cobramos venganza con ellos. Eso quedó así.

(...) Y ya le digo, la mayoría de los mayores ya murieron y ya de pronto hay por ahí nietos o bisnietos, pobrecitos quién sabe qué será de ellos.

De otra familia denominada La Tribu, se menciona que: “(..) Ellos viven aquí en Chaparral (...) Como le digo, ellos se agarraban entre sí, no sabían ni quien era la mamá, ni la nuera ni nada. Pues ahí salía hasta la abuelita."

Así, los personajes y actores de mayor recordación en El Codito, dentro de la población de adultos mayores, están asociados al ámbito político, al monopolio de la propiedad, a la prestación de servicios comunitarios y a la generación de conflictos y violencia.

\section{La relevancia del territorio en la construcción de comunidad en El Codito}

La inestabilidad es un lugar del que puede disfrutarse. Zygmunt Bauman. Comunidad, en busca de seguridad en un mundo hostil

La idea original de comunidad está estrechamente ligada al concepto de territorio, por representar este último el arraigo y por determinar muchas tradiciones y dinámicas propias de los grupos sociales. De esta manera, las comunidades establecen diversas formas de relacionarse con el territorio y le atribuyen al mismo diferentes significados; se construyen así los lugares sagrados, los lugares de esparcimiento, los lugares políticos y en fin, los lugares que dan forma a todas las manifestaciones de la vida social. Cada 
lugar será entonces testigo y actor de la vida de sus habitantes, al consolidar tradiciones, narrar historias y construir memoria.

El desvanecimiento de las fronteras, la velocidad y la accesibilidad, sin embargo, obligan a una reconceptualización del territorio, o mejor del espacio, en la que no será tan importante la consideración del espacio físico, como sí, la construcción social de espacios virtuales o "no reales", que, además, están llenos de significado y determinan actitudes y prácticas. En cualquier caso, el territorio se debe entender siempre como una construcción social, en la que mediarán diferentes variables particulares para cada caso. En este sentido, afirmamos con Chávez que: "El territorio, por principio, no es un espacio virgen, indiferenciado y neutral que sólo sirve como mero contenedor de la vida social y cultural, sino que se trata siempre de un espacio que ha sido valorizado ya sea instrumentalmente (bajo el aspecto ecológico, económico o geopolítico), o valorado culturalmente (bajo el ángulo simbólico-expresivo) (Chávez, s. f., p. 27).

Todo territorio se definirá entonces, en términos de los significados que le han sido atribuidos, que se pueden transformar o revalorizar, dependiendo de los actores o de los tiempos. Estos significados llenan de contenido el simple espacio físico y le otorgan un estatus de reconocimiento y legitimidad, dentro de las comunidades que lo usan, lo habitan o lo apropian. También Foucault hace énfasis en las características particulares que generan identidad, ya no en términos de territorio, sino de espacio; al respecto afirma:

No vivimos en un espacio homogéneo y vacío, sino, antes bien, en un espacio poblado de calidades, un espacio tomado quizás por fantasmas: el espacio de nuestras percepciones primarias, el de nuestros sueños, el de nuestras pasiones que conservan en sí mismas calidades que se dirían intrínsecas; espacio leve, etéreo, transparente o, bien, oscuro, cavernario, atestado; es un espacio de alturas, de cumbres, o por el contrario, un espacio de simas, un espacio de fango, un espacio que puede fluir como una corriente de agua, un espacio que puede ser fijado, concretado como la piedra o el cristal. (Foucault, 1967, p. 2) 
Foucault sostiene que la obsesión del siglo XIX fue la historia y que nuestra época es la época del espacio, para él, vivimos en el tiempo de la simultaneidad, de la yuxtaposición, de la proximidad y la distancia (ibídem, p. 1). El espacio, sin embargo, es también para Foucault una experiencia occidental, que tiene una historia particular; así, el espacio en la edad media era un conjunto jerarquizado de lugares, en el que unos se superponían a otros, configurando un espacio de localización. En este momento se tenía un ideal finito del espacio, que queda rebatido con los planteamientos de Galileo, quien erige un espacio infinito, en el que se remplaza la localización por la extensión. En la actualidad, la extensión se ve sustituida por la ubicación, que se define en términos de vecindad y de las relaciones que esta genera ${ }^{7}$ (ibídem, p. 1). Así, los espacios están definidos siempre en términos de relaciones, que, por supuesto, se consolidan como relaciones de poder.

En este sentido, al igual que el concepto de comunidad, se puede afirmar que el concepto de territorio se define también en términos de poder, encontrando que algunos lugares no son de libre acceso y están reservados solo para algunos miembros de la comunidad, sustentándose bien sea en normas establecidas o implícitas. Tal es el caso de algunos lugares considerados sagrados o de espacios que son apropiados por pequeños grupos, al establecer delimitaciones territoriales y fortalecer identidades. Respecto a la definición de territorio en términos de poder, afirma Chávez que:

Podemos hablar de las relaciones entre un grupo social y su territorio en términos de las relaciones de poder que lo definen y delimitan, de las instituciones que lo articulan y moldean, de la forma como se refieren los individuos a él y lo integran a su cultura y a su visión del mundo, de la manera en que lo transforman y modifican, o de como los límites físicos limitan el juego del poder y las propias relaciones sociales (s.f., p. 26).

$7 \quad$ El término vecindad sin embargo, ya había sido acuñado por Tonnies para la definición de las comunidades primarias y hacía referencia a la confluencia del espacio de vivienda con el espacio de trabajo. 
Así, el territorio se debe entender también como el marco de distribución de instituciones, actores y prácticas culturales particulares, y como las relaciones que se posibilitan entre ellos, y que generan, en ocasiones, pertenencia e identidad. En este sentido, el territorio más que algo físico, es un referente simbólico.

A diferencia de otros barrios, los del sector El Codito no se constituyeron en torno a un espacio público importante (plaza, iglesia, etcétera), consideramos que por ello, para sus habitantes no hay lugares muy representativos o simbólicos, las opiniones se dividen en lugares de comercio (tiendas, supermercados), lugares de especial importancia para los adultos mayores, como los puestos de salud o las iglesias, lugares que fueron importantes en el momento de fundación de los barrios, como la plaza de mercado de San Cristóbal, el primer jardín infantil —onstruido y mantenido con el esfuerzo de toda la comunidad-, la tienda de licores de Carlos Arango y la quebrada Zarauz o la de Servitá, y lugares y referentes espaciales de importancia actual como El Castillo, el colegio Don Bosco, el colegio San Juan en Usaquén y la huerta comunitaria.

El lugar más reconocido y legitimado por los pobladores del sector es el salón comunal que se consolida como el espacio de encuentro por excelencia, donde se toman decisiones, se realiza actividades recreativas y se efectúan reuniones. También se tienen referenciados espacios considerados negativos para la comunidad, como los expendios de droga u "ollas", en especial se menciona uno que está muy cerca al CAI (Comando de Atención Inmediata). Llama la atención que los parques no son nombrados como espacios de importancia para la comunidad de adultos mayores, lo que puede responder a la escasez de los mismos, al mal estado en el que se encuentran, a que se asocian con la inseguridad y el consumo de drogas, o a que son apropiados por otros grupos poblacionales.

Cada barrio tiene su memoria, sus hitos, sus territorios y sus actores, aunque muchas características son compartidas por todos los barrios del sector, según lo evidenció un diagnóstico poblacional realizado por la Universidad del Rosario en el año 2010. Barrios como Serrezuela, por ejemplo, carecen de servicio de acueducto y se proveen de agua con el limitado abastecimiento que ofrecen los carrotanques de la Empresa de Acueducto 
de Bogotá, para sus habitantes, este es el único problema del que adolece su comunidad, conformada por aproximadamente 80 personas, no se mencionan aspectos de seguridad o violencia, que sí se consolidan como común denominador de los barrios aledaños.

$\mathrm{Al}$ indagar por la historia y prospectiva de los barrios, identificamos algunos adjetivos de connotación negativa, en general, que se adjudican a cada uno de ellos y que se pretendieron sintetizar en el gráfico 1.

Gráfico 1. Propiedades de los barrios según la percepción de los habitantes del sector

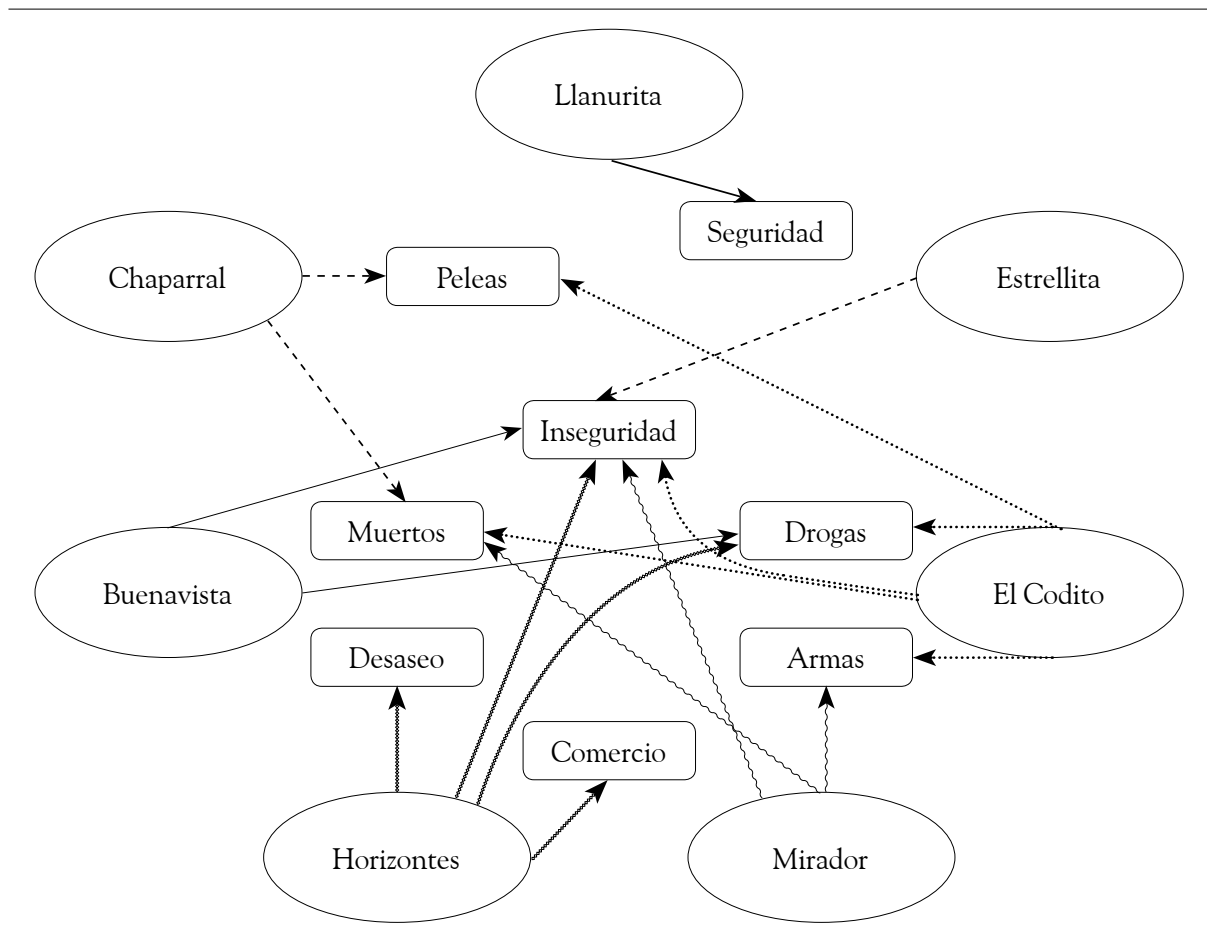

Fuente: elaboración propia

Como se puede observar, el único adjetivo positivo fue el de seguridad, adjudicado al barrio Llanurita, en donde se dice que gracias a su tamaño pequeño, no se han presentado atracos ni actos violentos, a diferencia de otros barrios en los que son común denominador. Así, la inseguridad se consolida como característica determinante de los barrios Mirador, Estrellita, El Codito, Horizontes y Buenavista, sin embargo, todos estos barrios 
no fueron inseguros siempre, de acuerdo a los testimonios de las personas entrevistadas, el sector era seguro hasta que se empezaron a construir los barrios Estrellita, Mirador y Buenavista, aún en la actualidad es común escuchar que la inseguridad viene de los barrios de arriba.

En general, todos los entrevistados concuerdan con que inicialmente el territorio era netamente rural y estaba constituido por potreros y matorrales, algunas familias se dedicaban a la cría de animales como marranos y ovejas, las viviendas eran precarias, construidas en tabla o en poli sombra y sin acceso a servicios públicos.

Como características particulares de cada barrio, se identificaron en las entrevistas las siguientes:

Tabla 3. Características de los barrios según los habitantes del sector

\begin{tabular}{|c|l|}
\hline Barrio & \multicolumn{1}{c|}{ Características } \\
\hline Llanurita & $\begin{array}{l}\text { Inicialmente, estaba compuesto por 35 familias. } \\
\text { Se utilizaba el "recibo de contribución", como una modalidad de pago de } \\
\text { impuestos. } \\
\text { Actualmente, no hay salón comunal, ni Junta de Acción Comunal. }\end{array}$ \\
\hline Chaparral & $\begin{array}{l}\text { Hizo parte del proceso Provivienda, de loteo y autoconstrucción. } \\
\text { Eran frecuentes las peleas y pedreas con la policía, en el marco de la apro- } \\
\text { piación de los lotes. }\end{array}$ \\
\hline Horizontes & $\begin{array}{l}\text { Pertenecía a José Domingo Cristancho. } \\
\text { Antes de la llegada de los servicios públicos, se construyó una letrina comu- } \\
\text { nitaria. }\end{array}$ \\
\hline Mirador & Se referencian permanentemente agentes de conflicto. \\
\hline
\end{tabular}

Fuente: elaboración propia

De esta manera, se presentan imaginarios y significantes de cada lugar y barrio, que parecen ser compartidos por la población de adultos mayores del sector, que, sin duda, variarán para los demás grupos etáreos y poblacionales.

Compuesto por 17 barrios y habitado por aproximadamente 32000 personas, el sector El Codito es absolutamente diverso y permite la formación de lazos sociales, en ocasiones muy fuertes, difusos y difíciles de percibir. 


\section{Conclusiones}

De acuerdo al análisis realizado, se puede afirmar que constantemente se construyen y reconstruyen comunidades, que guardan en ocasiones propiedades de las comunidades de antaño, pero que rara vez cumplen con todas sus características. No es posible entonces, hablar de "comunidad" en el sector El Codito, sino de comunidades y lazos sociales que se muestran más fuertes en ocasiones y más esquivos en otras. Es así, como la lucha por los servicios públicos es un gran hito dentro de la memoria colectiva de algunos de los barrios que componen el sector y tal vez sea la inspiración de nuevos barrios emergentes, que tienen un gran camino que recorrer en ese sentido. El territorio es otro componente que puede determinar a los habitantes del sector como "comunidad", sin embargo, el primer paso para que sea realidad es el auto reconocimiento como tal. El discurso de los líderes se enmarca en este sentido, aunque su poder de representación es cuestionado por situaciones como la baja participación de los habitantes en los espacios oficiales, o la solución de conflictos de orden social o comunitario.

Los actores identificados en el sector son de diversa índole y pueden ser internos o externos, de esta manera, se reconocen principalmente los grupos organizados en torno a: la edad de sus miembros, los intereses políticos, los intereses específicos y las instituciones prestadoras de servicios tanto del orden público, como del orden privado.

En general, para los participantes en este estudio, la comunidad tiene una connotación positiva, ligada a procesos solidarios, de trabajo en conjunto y de lucha por el logro de objetivos comunes. Se mantiene la idea de que la comunidad crece proporcionalmente al aumento de la población que habita un territorio, en este sentido, se confunde el término con la mera aglomeración de los habitantes de un lugar.

Hay una valoración positiva de las instituciones que hacen presencia en el sector, a través de programas y proyectos. Respecto de la atención que se le brinda al adulto mayor, también es importante mencionar los bonos que reciben de la Secretaría de Integración Social, a través del programa Subsidios económicos para personas mayores, pues son reseñados como una 
gran ayuda para el pago de servicios y alimentación, que, sin embargo, no dejan de generar conflicto al interior de las comunidades, pues no tienen una cobertura total y para poder acceder a ellos es necesario anotarse en una lista y esperar a que alguno de los beneficiarios fallezca, para otorgar el bono a un nuevo beneficiario. En ese sentido, la oferta institucional aunque percibida como positiva y en ocasiones como potenciadora de procesos comunitarios, se queda corta a la hora de brindar cobertura y calidad.

Los hitos del sector se relacionan principalmente con: la lucha por los servicios públicos y de movilidad, el abastecimiento de agua y víveres, la organización comunitaria y la intervención de agentes externos. En cuanto a ritos, se encontró que si bien no hay celebraciones autóctonas, se ha implementado el desarrollo de actividades y eventos, que cuentan con la participación y el reconocimiento de varios sectores poblacionales.

Cada uno de los 17 barrios de El Codito, tiene lugares y momentos específicos, que consolidan y fortalecen la memoria colectiva de sus habitantes y potencian o debilitan procesos comunitarios. También llama la atención, la dificultad para reconstruir la memoria colectiva de estos barrios, con excepción del barrio Horizontes, en el que se mantienen en el recuerdo de muchos de sus habitantes, sus procesos de poblamiento y de urbanización, así como los personajes que han hecho parte de los mismos.

En general, se han construido imaginarios negativos en torno a los diferentes barrios, así, se identifican características comunes a todos ellos, que tienen que ver con inseguridad, violencia y drogas. Por otro lado, por parte del grupo de adultos mayores, no hay apropiación de los espacios públicos, como parques o zonas abiertas para ellos, en cambio el salón comunal cobra vital importancia, al consolidarse como escenario de participación, recreación y encuentro.

\section{Bibliografía}

Álvaro, D. (marzo, 2010). Los conceptos de comunidad y sociedad de Ferdinand Tonnies. Papeles del CEIC, 2010/1 (52), pp. 1-24. 
Bauman, Z. (2003). Comunidad, en busca de la seguridad en un mundo hostil. Madrid: Siglo XXI de España Editores.

Bialakowsky, A. (2010). Comunidad y sentido en la teoría sociológica contemporánea: la propuesta de A. Giddens y J. Habermas. Papeles del CEIC, 2010/1(53), pp. 1-30.

Bourdieu, P. (1997). Razones prácticas sobre la teoría de la acción. Barcelona: Anagrama.

Chavez, T. (s.f.). Tiempo y espacio, territorio y memoria. Revista Universidad de Sonora, (21), pp. 25-28. Recuperado de http://www.revistauniversidad. uson.mx/revistas/21-Tiempo\%20y\%20espacio\%20territorio\%20y\%20 memoria.pdf

Durkheim, E. (1995). La división social del trabajo. Madrid: Akal.

Foucault, M. (14 de marzo de 1967). Los espacios otros. Conferencia dictada en el Cercle des études architecturals.

Guevara, J. \& Mendoza, M. (2011). Retos y avances del desarrollo local, caso El Codito. Bogotá: Universidad del Rosario.

Luna, E. (2010). Experiencia de apoyo al desarrollo local en el sector El Codito. En Universidad del Rosario. Universidad y sociedad, extensión universitaria, conocimiento y redes sociales (pp. 109-139), Bogotá D. C.: Autor. (Colección de Extensión).

Pérez, J. P. (enero de 2006). Globalización y comunidad de vecindad. Iconos Revista de Ciencias Sociales (24), pp. 27-42.

Simmel, G. (octubre, 2001). El individuo y la libertad. Ensayos de crítica de la cultura. Las grandes urbes y la vida del espíritu. Revista de Estudios Sociales, (10), pp. 107-109.

Simmel, G. (2002). Cuestiones fundamentales de sociología. Barcelona: Gedisa Editorial.

Touraine, A. (1997). ¿Podremos vivir juntos? Iguales y diferentes. Buenos Aires: Fondo de Cultura Económica de Argentina S. A.

Weber, M. (1994). Economía y sociedad. Bogotá: Fondo de Cultura Económica. 


\title{
Aproximaciones a la conformación histórica del territorio de El Codito. \\ Del estatisismo normativo a la construcción social
}

\author{
Juan David Guevara Salamanca*
}

* Politólogo de la Universidad del Rosario, se desempeñó como coordinador en terreno del proyecto Comunidad y territorio en el sector El Codito. Correo electrónico: juandguevara@gmail. com 
En el norte de Bogotá se erige un conjunto de casas pintorescas, diferenciadas unas de las otras por pequeños detalles, sobre las montañas orientales de la ciudad. Este sector recibe a los visitantes y habitantes de Bogotá que ingresan a la urbe capitalina por el norte de la ciudad y se conoce como el sector El Codito. ${ }^{1}$

A pesar de la aparente homogenización de las construcciones del sector, el proceso histórico de consolidación de este estuvo sujeto a relaciones conflictivas, confrontaciones violentas, regulaciones restrictivas, abandonos estatales y a la continua estigmatización de otros habitantes de la ciudad.

En el marco del presente libro se quiso indagar sobre la consolidación del territorio de El Codito. Este trabajo se enfocó en rehacer la historia del sector, desde sus inicios como haciendas y sitios de explotación de canteras hasta lo que hoy se observa en los cerros nororientales de la ciudad.

Como toda historia contada, este relato puede tener hechos difusos, contradictorios y, para algunos lectores, una historia diferente a la vivida. Por eso se quiere hacer claridad que este escrito obedeció a un trabajo investigativo que tenía como principal finalidad encontrar los elementos comunitarios que permitieron la construcción de los barrios del sector.

Aunque se tiene conocimiento de que El Codito está comprendido por 17 barrios, esta descripción histórica se centra en los barrios más representativos en términos de peso poblacional; por ello, se hace referencia a los barrios Horizontes, Buenavista (sectores I y II), Chaparral y El Codito. Se nombran en algunos casos a los barrios Estrellita Norte y Mirador del Norte como ejemplos concretos de situaciones históricas.

Este capítulo es el resultado de una revisión de la literatura existente sobre la historia de El Codito. El contenido específico sobre este sector fue tomado de escritos hechos por sus habitantes y corroborado a través de entrevistas realizadas a líderes y adultos mayores.

El capítulo se divide en: una primera fase contextual sobre la historia de la localidad de Usaquén; luego, se expone la visión de las autoridades distritales y nacionales sobre los cerros orientales (lugar de asentamiento de los barrios de El Codito), identificando algunas situaciones problemáticas y 
conflictivas sobre la normatividad existente; posteriormente, se detalla el proceso de asentamiento del sector, para cerrar el capítulo con la realidad actual del mismo.

\section{La ciudad y su conformación territorial}

A comienzos del siglo XX, Bogotá compartía las mismas características de las otras ciudades colombianas: no superaba los 100000 habitantes y la conservación arquitectónica de la ciudad colonial permanecía casi intacta, inclusive su perímetro era básicamente el mismo.

Zambrano et al. (2002) destaca que, para comienzos del siglo, la ciudad evidenció un marcado deterioro de las condiciones de vida de sus habitantes, lo que resultó en un descenso notorio de su población total. Así mismo, este evidente decrecimiento poblacional significó el debilitamiento de sus fronteras socio-culturales y elementos de jerarquización, lo que requirió el establecimiento de nuevas fronteras que sirvieran como puntos de diferencia entre los grupos sociales.

Hacia la década de los años veinte del siglo pasado la ciudad empezó un crecimiento desmesurado de población, lo que conllevó la extensión de su perímetro. Según un artículo publicado en el diario El Tiempo, "la población aumentó de 21934 habitantes en 1801 a 100000 en 1905 y a 200000 en 1927 [...] entre 1905 y 1927 Bogotá creció 3,6 veces su tamaño".

En los años treinta, Colombia empieza un proceso de industrialización derivado de la crisis en los países desarrollados y de las transformaciones políticas y sociales de comienzos de siglo. Zambrano et al. (2002) argumenta que este proceso no fue de industrialización sino de modernización derivado de la economía exportadora cafetera, lo que terminó por generar un avance urbano muy específico.

La modernización trajo consigo una serie de elementos que se conjugaron con los valores tradicionales propios de una sociedad y una economía agrarias; ello ha permitido hablar, desde ese entonces, "de una modernidad urbana con fuertes rasgos de sociedad tradicional" (ibídem, p. 221). El resultado de este proceso condujo a que el poder de las clases tradicionales 
no sufriera mayores retos en legitimarse y en manejar la transición modernizadora, sin negociar mayores prebendas ni controles (ibídem).

Bogotá, al ser centro político y económico del país, junto a Cali y Medellín, se volvió un polo de inmigración de personas que provenían de distintas partes de la geografía colombiana en busca de ser empleados como obreros y que buscaban resguardo y seguridad de la primera oleada de violencia política que azotó a Colombia.

Este proceso económico produjo cambios demográficos que modificaron radicalmente la dinámica de urbanización que traía la ciudad de Bogotá desde La Colonia; el centro de la ciudad se densificó, aparecen los "inquilinatos" como soluciones de vivienda para las familias migrantes que no encontraron un albergue independiente. Así, la población empieza a presionar las haciendas y ejidos ${ }^{2}$ ubicados en lo que era la periferia de la ciudad para allí establecer los primeros barrios denominados informales. ${ }^{3}$

De igual forma, el fenómeno de la inmigración del campo hacia las ciudades por razones de inseguridad se acrecienta en la segunda mitad del siglo XX en Colombia; se puede decir que los colonizadores de las periferias son emigrantes de primera o segunda generación que no encontraron respuesta a sus carencias de hábitat en el Estado ni fueron receptores del derecho a la seguridad por parte de los agentes estatales.

En los años sesenta el crecimiento poblacional había desbordado la capacidad de planeación del Estado y el retraso de vivienda calculado era de 22 años. Ante este contexto, el sector El Codito surge cuando la ciudad empieza a invadir las montañas de su borde oriental. Así, los primeros asentamientos se comenzaron a ubicar sobre la hoy conocida calle 174 por encima de la carrera séptima.

2 Los ejidos son tierras comunales cuya destinación estaba sujeta al goce y disfrute de la gente. Eran terrenos destinados al interés común lo que facilitaba el asentamiento de familias sin los recursos necesarios para subsistir en la ciudad.

3 Se denomina a estos barrios como informales dado a que no se observaron elementos técnicos ni de planeación en su construcción. 


\section{Elementos históricos de la conformación territorial de Usaquén}

La localidad de Usaquén, desde épocas coloniales, ha sido sujeta a ejercicios de planeación y definición de usos que, en ocasiones, riñen con la conformación social del espacio. Como ejemplo de este ejercicio de planeación externo, Zambrano et al. (2002) señala la fundación de la parroquia de Usaquén como forma de eliminar las tierras indígenas no comerciales y como inserción de un territorio estratégico: de movilidad y entrada a la capital durante la República y, en tiempos modernos, de contrabando, narcóticos e interacciones ciudad-región.

También se observa cómo el resguardo de indios de Usaquén fue trasladado a Soacha, lo que facilitó el uso económico de estas tierras ya que el pie y la falda de la montaña se convirtieron en tierras de ganado y agricultura. Ello condujo a que se posicionaran como proveedoras de alimentos de la capital del Virreinato.

De este modo, la lógica del español blanco se impuso sobre los territorios anteriormente indígenas; el control se realizó mediante el poblamiento sistemático a través de la instalación de familias completas, la adecuación de inmobiliarios y redes para incrementar la habitabilidad de la ciudad y el mantenimiento de las relaciones de dominación con la población indígena (ibídem).

Años posteriores a la expulsión de los conquistadores españoles, la concentración de la tierra a lo largo y ancho del territorio nacional se localizó en pocas manos; para comienzos del siglo XX, y a pesar del nuevo fenómeno de parcelación, la distribución efectiva de la tierra no logró su objetivo. Zambrano et al. (2002) argumenta que el propósito distribuidor no se cumplió debido a que, en su mayoría, quienes se hicieron arrendatarios de los nuevos lotes y terrenos eran medianos propietarios cuyo objetivo era consolidar un extenso territorio a partir de la adquisición de pequeñas parcelas.

Es claro que el territorio de Usaquén no escapó a esa dinámica nacional ni a otros procesos que envolvían el desarrollo de Bogotá. 
Usaquén ejemplificó el repartimiento de tierras indígenas que se estableció en la sabana de Bogotá, en la que predominaron los intereses de los grandes terratenientes y la extinción de la pequeña propiedad (ibídem). Entonces, desde finales del siglo XIX y la primera mitad del XX, Usaquén se erigió como un territorio estratégico para el desarrollo de la ciudad: primero, como principal proveedor de piedra y arena para su construcción; ${ }^{4} y$ segundo, como era el poblado más cercano al norte de Bogotá, se convirtió en la puerta de entrada a la capital (ibídem).

\section{Usaquén se anexa a Bogotá}

En el año de 1955, la ciudad de Bogotá se convierte en Distrito Especial. Este cambio se produjo con la anexión de los municipios vecinos de Bosa, Usme, Fontibón, Engativá, Suba y Usaquén. Desde ese momento, el municipio de Usaquén pasa a ser considerado una unidad territorial de la capital de Colombia.

Una de las razones por las cuales se produjo la anexión de estos municipios a Bogotá fue la búsqueda de independencia de la ciudad sobre la autoridad del departamento de Cundinamarca. No obstante, la presión propia del crecimiento urbano y la conexidad proveniente de diferentes proyectos de infraestructura también son causantes de esta anexión impuesta.

Zambrano et al. (2002) expresa que uno de los problemas con los que han lidiado las diferentes administraciones de la ciudad ha sido el crecimiento desmedido de la población bogotana a lo largo del siglo XX; cuestión que ha significado la disociación entre la planeación técnica y la definición de políticas desarrollistas estatales para la ciudad. En efecto, "Este crecimiento acelerado acarreó una urbanización descontrolada, donde los barrios marginales accedían a su normalización urbanística gracias a la mediación de algunos políticos inescrupulosos" (ibídem, p. 258).

4 Se dice inclusive que la piedra y arena con que se construyó el antiguo Palacio de Justicia y el Congreso de la República salieron de estas montañas. Recuperado de http://www.ciudadbogota. $\mathrm{com} /$ conte/historia/localidades/usaquen.htm 
Este suceso se complementa con la construcción de proyectos de infraestructura de cierta envergadura que facilitaban el acceso a diversos predios y la posibilidad de su negociación. Con la llegada de nuevos habitantes a los territorios deshabitados se aumentó la demanda de servicios públicos (ibídem).

Particularmente, la anexión de Usaquén, al ser un sitio de extracción de recursos naturales se podría relacionar con la búsqueda de recursos a menor costo que se utilizaran como insumos en la construcción de los nuevos asentamientos citadinos. La importancia de Usaquén como proveedor de recursos para la construcción ha dejado su huella sobre los cerros orientales de la ciudad. A ello se debe gran parte del debate sobre la definición de la reserva forestal sobre estos cerros.

En los años setenta, la política estatal de promoción de vivienda generó fuertes transformaciones en el espacio de la localidad. No sólo por la innumerable cantidad de proyectos de vivienda que se ejecutaron en la época, sino porque además el UPAC ${ }^{5}$ posibilitó la construcción de zonas comerciales, como el centro comercial Unicentro (ibídem, 2002).

Aunque estos proyectos hicieran parte de la planeación distrital contrastan con otros procesos de asentamiento y urbanización al interior de la localidad, como los que se observarán más adelante y que ayudaron a conformar el sector El Codito.

Antes de avanzar y adentrarnos en el caso de El Codito, se quiere reseñar la importancia que tiene para el sector el asentarse sobre los cerros orientales de la ciudad.

5 La Unidad de Poder Adquisitivo Constante (UPAC) fue un sistema de crédito hipotecario que se implantó en el gobierno de Misael Pastrana Borrero (1970-1974) que le permitía a los colombianos adquirir viviendas a largo plazo. 
62

\title{
La barrera natural de Bogotá: los cerros orientales
}

\author{
Juan David Guevara Salamanca \\ Con la colaboración de Natalia Molina Llano 6
}

Los cerros orientales de Bogotá son considerados de alta importancia para la ciudad y la región de Cundinamarca: por un lado, se constituyen como emblema que representa una identidad cultural de los bogotanos y se conciben como el principal referente paisajístico de la Capital, dada su "calidad escénica, dominancia visual y los valores intrínsecos (naturales) y los adquiridos (históricos y culturales)" (Mesa Ambiental de Cerros Orientales, 2008, p. 23); por otro lado, los cerros han sido, desde sus inicios, un escenario de gran importancia y valor ecológico, pues además de ser la más grande fuente de agua y oxígeno de la ciudad, recursos necesarios e imprescindibles para la supervivencia del ser humano, albergan miles de especies de fauna y flora, son el corredor ecológico que une al Parque Natural Nacional Chingaza con el Parque Natural Nacional Páramo de Sumapaz. Por lo anterior, se consideran "un eje ambiental de vital importancia que garantiza la calidad ambiental, la conectividad ecológica y la disponibilidad de servicios ambientales del Distrito, el cual forma parte de la Estructura Ecológica Principal de la Ciudad" (Personería de Bogotá, 2007, p. 10).

Así como el aspecto ecológico recobra gran importancia, los cerros también son residencia de distintos procesos urbanos en el que familias y comunidades han hecho de estos territorios el locus donde han desarrollado sus vidas, han tejido sus sueños y construyen prácticas familiares y comunitarias. Miles de personas han encontrado en los cerros orientales un lugar donde vivir, donde satisfacer sus necesidades básicas, donde ejercer sus derechos. Su historia, el trabajo realizado, la consolidación de los barrios, entre otras cosas, hacen que estas miles de familias sientan y conciban los cerros no solo como un espacio natural de importancia ecológica y paisajística, sino que identifiquen su sitio de residencia como su territorio.

6 Fonoaudióloga de la Universidad del Rosario. Especialista en Salud Pública de la Universidad del Rosario. Correo electrónico: namollan@gmail.com 
Dado a la permanente acción del hombre sobre este territorio, no solo por la ocupación territorial, sino además por la importancia recursiva, principalmente para los constructores de la ciudad, se inicia desde las diferentes instancias gubernamentales una avanzada normativa para preservar la riqueza ecológica y natural de los cerros y para evitar las acciones destructivas de la mano humana.

De esta manera, se han expedido normas que han oscilado entre las visiones de preservación, las cuales "restringen en mayor medida los usos de suelo sobre el área de la reserva y por lo mismo la presencia humana en la zona" (Bohórquez, 2008, p. 235), y las de conservación.

Lamentablemente, y aunque en la actualidad se lleva a cabo un proceso definitivo en el Consejo de Estado, ninguna definición normativa ha buscado conciliar las necesidades ecológicas y de preservación con las necesidades e intereses de los pobladores de la ciudad. Se espera que la resolución jurídica del Consejo de Estado defina, de una vez por todas, la situación de incertidumbre y abandono que reina las realidades de los cerros orientales.

\section{Desarrollo histórico de los cerros orientales}

Desde la Colonia, la explotación descontrolada, insostenible e intensiva marca la vida futura de los cerros orientales de Bogotá (Camargo, 2001). Esta explotación colonial va a tener sus raíces en los intereses y necesidades dominativas de los españoles por derrocar las deidades muiscas, cuya identidad está fuertemente relacionada con el territorio.

De hecho, esta porción territorial tenía un valor y significado religioso para la cultura muisca: algunas especies de animales y lugares sagrados, en particular las lagunas, cuyo hábitat son los cerros, servían como tótem dedicados a la adoración y a la realización de cultos y ceremonias.

Por esta razón, los españoles, en su afán de exterminar las creencias paganas y de "civilizar" a los "salvajes", ordenaron la tala de los bosques de nogales, encenillos, cedros gigantes y otras especies nativas para evitar que los muiscas adoraran estos árboles, y así aprovechar la buena madera para la construcción de templos y casas, y la elaboración de muebles y enseres para personajes ilustres de la época (Personería de Bogotá, 2007, p. 19). 
En los años treinta y cuarenta de la centuria pasada, la mayor parte de los cerros estaba por completo deforestada debido al uso de la madera para la subsistencia humana: la construcción de las casas, la calefacción de las viviendas, la cocción de los alimentos, entre otros, fueron los detonantes de esta destrucción.

A mediados de los años cincuenta se inicia un arduo proceso de reforestación con especies foráneas como los pinos de pátula, eucaliptos, cipreses y acacias, con el fin de volver a cubrir el cerro de vegetación. Sin embargo, estas plantaciones forestales exóticas no nativas producirían unas transformaciones no sólo en el paisaje de la ciudad sino en el ecosistema de los cerros.

De hecho, estas nuevas especies alteran la "dinámica hídrica de las microcuencas, proceso reflejado en la desaparición de cauces, disminución de la infiltración en las áreas de recarga, degradación de suelos y aceleración de procesos erosivos" (Díaz, s. f. p. 4). En el año 2006, según el Plan de Manejo Ambiental dado por la CAR, el 18\% del total de las hectáreas de la reserva forestal, sufre una amenaza en su estabilidad ecológica por el uso del suelo en dichas plantaciones forestales foráneas (Corporación Autónoma Regional de Cundinamarca, 2006).

En esa misma década, se vive en el país una gran migración de personas desplazadas por la violencia y por la carencia de trabajo rural que, dejando sus tierras y pertenencias, llegan a la capital en busca de empleo, una vivienda digna y una nueva posibilidad de rehacer sus vidas y sueños. Entonces, estas familias llegan a lugares de la ciudad en los que es posible acceder a una solución de vivienda a bajo costo, lo que lleva a que surjan asentamientos humanos en zonas no aptas para construcción con pocas condiciones de seguridad. Así, "se forma una población urbana marginal, excluida, estigmatizada y abandonada por el Estado en su conjunto" (Alcaldía Mayor de Bogotá, 2006, p. 7).

En los primeros años de la década del setenta, el Distrito lanza, en asocio con el Banco Interamericano de Desarrollo (BID), el Programa Integral para el Desarrollo Urbano de la Zona Oriental de Bogotá (Piduzob), cuya obra principal fue la construcción de la Avenida de los Cerros, hoy 
Avenida Circunvalar. El propósito de esta obra era integrar el norte con el centro de la ciudad, aprovechando las laderas de las montañas orientales.

\section{La explosión normativa}

Siguiendo la tradición santanderista, elemento identitario de la nación colombiana, el inmenso número de leyes, decretos, acuerdos, ordenanzas cuyo principal objetivo ha sido el de regular la vida social, económica, política y ecológica sobre los cerros, ha carecido de efectos y sentido al no tener en cuenta las poblaciones asentadas sobre estos territorios.

Así, existe una ubérrima normatividad que en no pocas ocasiones llama a la contradicción y el descontento al expresar puntos confusos sobre las posibilidades y prohibiciones del uso del suelo de la reserva, sin contar los desentendidos en cuanto a la definición misma de la reserva. Muchos lineamientos y principios se presentan como faltos de claridad y con vacíos jurídicos.

A continuación, se presenta la normatividad que se ha expedido para el manejo de los cerros orientales de Bogotá y la cual fue hallada en este proceso de entendimiento sobre la realidad jurídica de esta región tutelar de la ciudad.

Tabla 1. Normatividad para el manejo de los cerros orientales

\begin{tabular}{|l|l|}
\hline \multicolumn{1}{|c|}{ Norma } & \multicolumn{1}{c|}{ Descripción } \\
\hline $\begin{array}{l}\text { Acuerdo N. }{ }^{\circ} 30 \text { de } 1976 \\
\text { del Inderena }\end{array}$ & $\begin{array}{l}\text { Alindera y declara los cerros orientales como Área Forestal } \\
\text { Protectora Bosque Oriental de Bogotá y delega su administra- } \\
\text { ción en la CAR. }\end{array}$ \\
\hline $\begin{array}{l}\text { Resolución N. }{ }^{\circ} 76 \text { de } \\
1977 \text { del Ministerio de } \\
\text { Agricultura }\end{array}$ & $\begin{array}{l}\text { Adopta y eleva a categoría de decreto nacional el Acuerdo 30 } \\
\text { de 1976 del Inderena. }\end{array}$ \\
\hline $\begin{array}{l}\text { Acuerdo 1 de 1986 del } \\
\text { Concejo de Bogotá }\end{array}$ & $\begin{array}{l}\text { Se ordena la legalización de un conjunto de desarrollos exis- } \\
\text { tentes a la fecha de su expedición. Visibiliza la legalización } \\
\text { de 27 asentamientos localizados en el borde oriental de la } \\
\text { ciudad. }\end{array}$ \\
\hline
\end{tabular}




\begin{tabular}{|c|c|}
\hline Norma & Descripción \\
\hline $\begin{array}{l}\text { Acuerdo } 59 \text { de } 1987 \text { de } \\
\text { la CAR (derogado por el } \\
\text { Acuerdo } 38 \text { de 1990) }\end{array}$ & $\begin{array}{l}\text { Por el cual se expide la reglamentación de los cerros orienta- } \\
\text { les de Bogotá. Establecía unas normas de manejo ambiental y } \\
\text { paisajístico para la conservación de la reserva, atendiendo a } \\
\text { las distintas situaciones de hecho y potenciales, por medio de } \\
\text { una zonificación. Es derogado pues contiene normas de uso } \\
\text { e índices de ocupación para las diferentes zonas por lo cual } \\
\text { adquiere perfil de norma urbanística. }\end{array}$ \\
\hline Acuerdo 6 de 1990 & $\begin{array}{l}\text { Por medio del cual se adopta el estatuto para el ordenamiento } \\
\text { físico del Distrito Especial de Bogotá y se dictan otras dispo- } \\
\text { siciones. Responde a la obligación impuesta por la Ley } 9 \text { de } \\
1989 .\end{array}$ \\
\hline Acuerdo 38 de 1990 & $\begin{array}{l}\text { Se ratifica la Resolución } 76 \text { de } 1977 \text { como norma de cerros } \\
\text { orientales, interpretada la reserva en sentido del uso forestal } \\
\text { exclusivo. }\end{array}$ \\
\hline $\begin{array}{l}\text { Resolución } 2413 \text { de } 1993 \\
\text { de la CAR }\end{array}$ & $\begin{array}{l}\text { Por la cual se sustrae un área de la Reserva Forestal Protecto- } \\
\text { ra Bosque Oriental de Bogotá. } \\
\text { "Aprovechando el antecedente creado por la Resolución } \\
2337 \text { de } 1985 \text { (cuando la CAR sustrae el sector de San Luis- } \\
\text { La Sureña), la Sociedad Reforestadora Puente Chicó solicita } \\
\text { que los terrenos de su propiedad (aledaños a La Sureña) sean } \\
\text { sustraídos de la Reserva Forestal Protectora, alegando que } \\
\text { continuamente son invadidos ilegalmente por las personas } \\
\text { procedentes de los barrios legalizados vecinos, lo que permi- } \\
\text { te la extensión de la urbanización sobre la quebrada Chicó" } \\
\text { (Camargo, s. f., p. 11). }\end{array}$ \\
\hline $\begin{array}{l}\text { Acuerdo } 31 \text { de } 1996 \text { del } \\
\text { Distrito }\end{array}$ & $\begin{array}{l}\text { Por el cual se adopta el Plan de Ordenamiento Físico del Borde } \\
\text { Norte y Oriental de la Ciudad de Santa Fe de Bogotá D. C., } \\
\text { se establecen las normas urbanísticas y las medidas para la } \\
\text { preservación, protección y adecuado uso de las áreas que } \\
\text { conforman dichos sistemas y se dictan otras disposiciones. }\end{array}$ \\
\hline Decreto 619 de 2000 & $\begin{array}{l}\text { Por el cual se adopta el Plan de Ordenamiento Territorial } \\
\text { para Santa Fe de Bogotá, D. C. Se incluye dentro del Sistema } \\
\text { de Áreas Protegidas del Distrito Capital, la Reserva Forestal } \\
\text { Protectora Bosque Oriental de Bogotá, como un área protegi- } \\
\text { da del orden nacional. }\end{array}$ \\
\hline $\begin{array}{l}\text { Plan de Ordenamiento } \\
\text { y Manejo de los Cerros } \\
\text { Orientales de Bogotá } \\
\text { (Pomco) del año } 2004\end{array}$ & $\begin{array}{l}\text { Elaboración de un diagnóstico de los cerros orientales, análi- } \\
\text { sis prospectivo y zonificación de manejo. }\end{array}$ \\
\hline
\end{tabular}




\begin{tabular}{|l|l|}
\hline \multicolumn{1}{|c|}{ Norma } & \multicolumn{1}{c|}{ Descripción } \\
\hline $\begin{array}{l}\text { Resolución N. }{ }^{\circ} 463 \text { de } \\
\begin{array}{l}\text { Ambiente, Vivienda y } \\
\text { Desarrollo Territorial }\end{array}\end{array}$ & $\begin{array}{l}\text { Redelimita la Reserva Forestal Protectora Bosque Oriental de } \\
\text { Bogotá, se adopta su zonificación y reglamentación de usos y } \\
\text { se establecen las determinantes para el ordenamiento y ma- } \\
\text { nejo de los cerros orientales de Bogotá. }\end{array}$ \\
\hline $\begin{array}{l}\text { Resolución DAMA 1043 } \\
\text { del 28 de abril del 2005 }\end{array}$ & $\begin{array}{l}\text { Por medio de la cual se establece una medida preventiva y se } \\
\text { toman otras determinaciones en relación con la reglamen- } \\
\text { tación adoptada por el Ministerio de Ambiente, Vivienda y } \\
\text { Desarrollo Territorial, para el Área de Reserva Forestal Pro- } \\
\text { tectora Bosque Oriental de Bogotá, D. C. }\end{array}$ \\
\hline $\begin{array}{l}\text { Resolución 463 de 2005 } \\
\text { del Ministerio de Am- } \\
\text { biente, Vivienda y Desa- } \\
\text { rrollo Territorial }\end{array}$ & $\begin{array}{l}\text { Por medio de la cual se redelimita la Reserva Forestal Protec- } \\
\text { tora Bosque, se adopta su zonificación y reglamentación de } \\
\text { usos y se establecen las determinantes para el ordenamiento y } \\
\text { manejo de los cerros orientales de Bogotá. }\end{array}$ \\
\hline $\begin{array}{l}\text { Decreto (distrital) } \\
\text { N. }{ }^{\circ} 122 \text { de 2006 }\end{array}$ & $\begin{array}{l}\text { Por el cual se adoptan medidas de defensa y protección de la } \\
\text { Reserva Forestal Protectora Bosque Oriental de Bogotá. }\end{array}$ \\
\hline $\begin{array}{l}\text { Resolución N. }{ }^{\circ} 1141 \text { de } \\
\text { 2006 de la Corporación } \\
\text { Autónoma Regional de } \\
\text { Cundinamarca }\end{array}$ & $\begin{array}{l}\text { Adopta el Plan de Manejo Ambiental de la Zona de Reserva } \\
\text { Forestal Protectora Bosque Oriental de Bogotá. }\end{array}$ \\
\hline
\end{tabular}

\section{Urbanización de los cerros}

El proceso de urbanización de los cerros orientales inició mucho antes de que estos fueran declarados reserva natural en 1976. No solo ha sido el asentamiento de gentes avenidas a marginalizadas y excluidas, como las poblaciones de El Codito, sino también les han sido sitio de residencia de personas lo suficientemente incluidas y poderosas para violar la norma (Camargo, 2001).

La mayoría de predios que no fueron adquiridos por la Empresa de Acueducto y Alcantarillado de Bogotá, con el fin de preservarlos, se fueron transformando o ya eran canteras, tugurios, proyectos institucionales o condominios de lujo. Pese a lo reglamentado en todos los acuerdos, resoluciones y decretos concernientes a la preservación y conservación de los recursos naturales no renovables y el paisaje como patrimonio común de la humanidad, las autoridades ambientales, motivadas por razones urba- 
nísticas, autorizaron (mediante resoluciones y actos legislativos) sustraer áreas de la "zona de Reserva Forestal de los Bosques Orientales", antes que ejercer verdaderas y efectivas acciones para su preservación.

Así las cosas, específicamente en estratos socioeconómicos 1 y 2 el proceso de desarrollo urbano se inició, de una parte, con el asentamiento de familias que al dedicarse a la extracción de materiales para la construcción decidieron establecerse en los cerros orientales cerca a su lugar de trabajo; y, de otra, la llegada de personas que por el bajo costo del predio y las oportunidades de adquisición se instalan en ellos. Desde entonces, ha existido un proceso de expansión urbana subnormal que roba permanentemente territorio a la reserva forestal y deteriora los recursos naturales y el ecosistema.

La conexión ilegal a los servicios públicos era parte de la cotidianeidad de los habitantes de los cerros. El loteo de haciendas existentes desde épocas coloniales fue una práctica común que, sin legislación y control de las autoridades, les permitió a muchos habitantes tener una fracción de tierra donde vivir.

Mientras tanto, las autoridades de la ciudad definían políticas para ponerle freno al crecimiento informal y no planificado de Bogotá. Así, en el año de 1968 se expide la Ley 66 que tenía como objetivo regular el uso de la tierra en las ciudades y penalizar la venta ilegal de lotes y las urbanizaciones "piratas".

Posteriormente, se crea el Comité Permanente de Control y Administración de Urbanizaciones teniendo como labor principal vigilar los procesos de construcción llevados a cabo en la ciudad. Su primera tarea fue la de realizar un censo sobre los denominados "barrios piratas"; en marzo de 1975, el estudio arrojó que de 698 barrios que había en Bogotá solo 400 eran legales (El Tiempo, 1975).

Algunos de los barrios actuales, tanto como los que se encuentran legalizados como aquellos que aún no han sido reconocidos, se iniciaron como procesos de invasión o como producto del pago del trabajo realizado en las canteras por parte de los dueños de las haciendas y los chircales.

Es preciso anotar que desde que los cerros orientales fueron declarados reserva forestal, se han percibido múltiples inconsistencias por parte de 
las autoridades y entidades del Estado en temas relacionados con la adjudicación de licencias, la legalización de barrios y la prestación de servicios públicos domiciliarios.

En lo relacionado con estos últimos, en un comienzo la mayoría de los barrios no contaban con servicios de electricidad, agua y alcantarillado por lo cual les era necesario "contrabandear" o buscar la forma de autodotarse dichos recursos. Con el paso del tiempo, la realidad de la ciudad fue exigiendo a las empresas y al distrito que esos servicios fueran provistos y, por esto, en 1998 la Empresa de Acueducto y Alcantarillado de Bogotá desarrolla el "Programa de Desmarginalización, el cual es avalado por la Nación y se financia con recursos del Banco Mundial y del Banco Popular. A través de dicho Programa se suministra agua a más de 650 barrios promovidos por urbanizadores piratas, varios de ellos localizados dentro de la reserva forestal” (Alcaldía Mayor de Bogotá, 1998, p. 12).

Algunos sectores y barrios lograron conseguir la prestación de los servicios aun estando inmersos en el área protegida. Sin embargo, muchos otros todavía no logran el acceso a estos.

Actualmente, el sector El Codito tiene una cobertura casi total de los servicios públicos. Según Mendoza y Guevara (2012), en el sector hay una cobertura del 100\% de energía eléctrica, 94\% de acueducto, 91\% de alcantarillado y $89 \%$ de gas natural. Los barrios Serrezuela, Lomitas, La Capilla, Mirador del Norte y un sector de Balcones de Vista Hermosa, desde hace aproximadamente 30 años, han tenido que enfrentar un problema de cobertura en los servicios de acueducto y alcantarillado pues al ser barrios no legalizados y que se encuentran ubicados en medio de la reserva forestal, no reciben respuesta positiva por parte de las empresas prestadoras de estos servicios por la imposibilidad de intervenir en zonas no permitidas.

Así mismo, en relación con el servicio de gas natural, según comentan algunos habitantes de los barrios en mención, tan solo desde hace menos de un año, se logró, por intermediación de algunos líderes comunitarios, que la empresa Gas Natural realizara la instalación de redes. Esto da cuenta de las dificultades presentes para los habitantes de estos barrios.

Por otro lado, en lo relacionado con los estratos socioeconómicos 5 y 6, al amparo de supuestas plantaciones forestales privadas, en zonas que 
fueron sustraídas de la reserva forestal por resoluciones de la CAR y que actualmente se consideran nulas, se inició la construcción de urbanizaciones, edificios, instituciones educativas, que asumen un modelo sostenible que permita mantener un equilibrio entre la naturaleza y el hombre. Pese a eso, la urbanización y construcción ha implicado deforestación, la ruptura del curso normal de corrientes hídricas y por ende del ecosistema (Camargo, s. f., p. 9).

Se podría resumir que los procesos de asentamiento en los cerros se caracterizan, entre otros aspectos, por: el tráfico de influencias para la otorgación de licencias de construcción, la prevalencia de algunos intereses económicos empresariales — como el caso de las canteras-, la abundante y confusa legislación existente sobre el tema, la carencia de moralidad administrativa de algunos servidores públicos, el soslayo de la ley por parte de algunos habitantes de los cerros, entre otros aspectos (Alcaldía, 2006).

\section{El hombre y la naturaleza. ¿Determinantes en la política pública sobre los cerros orientales de Bogotá?}

La Resolución 76 de 1977 del Ministerio de Agricultura, en la cual se "alinda y declara la Reserva Forestal Protectora del Bosque Oriental de Bogotá”, fue la primera iniciativa en proteger a los cerros orientales y la preservación de sus recursos naturales no renovables. Sin embargo, al tener en cuenta las restricciones que en términos de uso, aprovechamiento y transformación de las áreas que estaban allí implícitas, y que se consideraba ilegal la reglamentación de los procesos urbanos como el ordenamiento del comercio, los corredores viales y la expansión suburbana, procesos que se venían adelantando desde hacía más de 20 años, se considera esta resolución como el punto de partida para la problemática y el debate actual de esta zona de la ciudad (Camargo, s. f., p. 10).

La forma como las entidades estatales han interactuado con las poblaciones asentadas en estos territorios se ha limitado a la promulgación de normas, acuerdos, resoluciones y leyes. Ello ha consolidado procesos unilaterales en los cuales se desconocen por completo las percepciones, intereses y necesidades de los pobladores dando relevancia a los valores e 
intereses ambientales y paisajísticos. En pocos momentos se han utilizado herramientas de planeación y participación ciudadana para formular planes y normas, lo que limita la posibilidad de conocer la definición social y espacial de la zona de reserva forestal y de la supuesta zona de adecuación, la construcción del sentido de pertenencia y el fomento al cuidado y sostenibilidad de la reserva. Este proceso ha generado un "efecto social y ambiental negativo, al simbolizar los elementos naturales como antivalores del desarrollo" (ibídem, p. 11).

Pese a la existencia de la Mesa Ambiental de los Cerros Orientales con sus propuestas y documentos que han sido presentados al gobierno distrital, aún no se cuenta con elementos de planeación que logren la confluencia de los intereses urbanos, locales, distritales, económicos, ambientales y sociales.

Al considerar la política pública como "un programa de acción gubernamental que tendría por lo menos cinco fases -identificación de un problema, formulación de soluciones, toma de decisión, implementación y evaluación-" (Bohórquez, 2008, p. 231), se puede concluir que aún no se cuenta con una política pública integral para los cerros orientales.

A pesar de que existe un sinnúmero de normas, la realidad jurídica colombiana y la fáctica realidad de los cerros orientales nos lleva a concluir que no es necesaria la existencia de una política pública de los cerros si esta no se identifica, formula, ejecuta y evalúa bajo preceptos participativos, con el ánimo de lograr el efectivo cumplimiento de la legislación de los cerros.

En este orden de ideas, el hombre y la naturaleza son concebidos como elementos que en vez de compenetrarse y complementarse, actúan como enemigos y obstáculos para el desarrollo de cada cual, dejando de ser vistos como "elemento y conjunto, sino como dos antagonistas, dos existencias recíprocamente excluyentes" (Camargo, 2006, p. 2). La realidad de los cerros parece contener estos elementos contradictorios pero complementarios. Falta ver cómo se resuelve el embrollo jurídico y si se desencadenan propuestas sostenibles para las poblaciones y la riqueza ecológica de los cerros orientales de Bogotá.

En el marco de las propuestas alternativas se quiere hacer especial mención a la propuesta del Pacto de Bordes, impulsada y expuesta por actores como Hernando Gómez (ex alcalde de Chapinero) y la Asociación de 
Cerros Orientales de Bogotá. Esta propuesta parece encajar en la fórmula hombre-naturaleza al traspasar la responsabilidad de preservación y conservación del recurso natural a los pobladores de los barrios ubicados sobre los cerros orientales. Aquí, el recurso natural queda en manos de los habitantes de las montañas capitalinas quienes deben conjugar la convivencia con el respeto por la naturaleza.

\section{De lo local a lo barrial. Procesos históricos de conformación territorial del sector El Codito}

En el siguiente apartado se propone hacer un recorrido por la consolidación espacial de El Codito. La forma que se hace la apropiación del territorio y el papel de los actores que facilitaron este proceso son los puntos de mayor importancia en este acápite.

También se hace especial énfasis en las luchas sociales del sector, cuyo elemento compartido se puede observar en otros territorios. El acceso a los servicios públicos domiciliarios y el reconocimiento de las autoridades distritales fueron los hechos más representativos de los primeros días de El Codito.

\section{El modelo hacendista como crisol de los años venideros}

El poblamiento de El Codito obedece al proceso de urbanización histórico de la ciudad de Bogotá y, en particular, de la actual localidad de Usaquén. En este proceso, la conformación del territorio recibe influencias de la organización espacial de la colonia española, del lento poblamiento de los primeros años de la República y de la explosión urbana de la década de los años cuarenta del siglo pasado.

En el momento de la anexión a Bogotá, el hoy llamado sector El Codito tenía solo tres casonas: la finca Horizontes, la finca La Estrellita y una casona que se proyectó como la urbanización Buenavista que nunca llegó a concluirse. En especial, estas fincas obedecieron al sistema hacendista que reinó en Colombia como modelo definitorio y organizador del espacio social, 
económico y cultural, igualmente, como expresión histórica del territorio y como ejercicio productivo que primó hasta el siglo XX.

Este modo de organización del territorio se basaba en la tenencia de grandes extensiones o latifundios de tierra en manos de pocas personas o familias, como lo expone Zambrano et al. (2002).

Se aclara que, aunque las tierras de El Codito no comparten la extensión que otros terrenos tenían en Colombia, la lógica productiva del espacio obedecía a los mismos patrones de las grandes haciendas.

Según Guillén (1979), el modo de producción de la hacienda tuvo su sustento en la cada vez más deficiente producción de explotación agraria de los resguardos indígenas; la dación de recompensas militares con la concesión de tierras públicas, tierras baldías o confiscadas en manos del Estado; la destrucción de los centros de producción manufacturera artesanal del nororiente del país; y de la apertura aduanera al comercio internacional.

Con la Hacienda, la estructura económica del país se perfiló como exclusiva productora de alimentos y materias primas; pero no sólo se convirtió en estructurador económico sino además moldeó las relaciones políticas y sociales (Guillén, 1979).

El poder expedido desde la Hacienda se basaba en el libre cambio, en la práctica del monocultivo exportador, en la centralización del poder y las alianzas de clase, y en el mantenimiento de la subordinación social y hereditaria (Guillén, 1979). Principalmente, este modelo se expandió por el centro del país, a excepción del occidente antioqueño y del viejo Caldas. Este modo de producción económico, espacial, político y social dominó la escena colombiana hasta la segunda mitad del siglo XX.

Para Usaquén, la forma de Hacienda se asume en su singular forma ganadera, lo cual sirvió para reforzar la idea de diferenciación social del espacio. ${ }^{7}$ Diferencia que hoy día se percibe en la estratificación de la localidad cuya población mayoritaria pertenece a los estratos 5 y 6 .

Un hecho para resaltar es que las haciendas dedicadas a la ganadería extensiva no necesitan gran cantidad de mano de obra, diferente a las ha-

7 Se destaca el hecho de que a lo largo del siglo XIX y comienzos del XX, las tierras de Usaquén servían como sitio de descanso y recreo para las familias acomodadas de la sociedad bogotana. 
ciendas dedicadas a la agricultura. Esto fue determinante en el proceso de poblamiento en el siglo XIX dado que Usaquén no logró concentrar la misma cantidad de población que en los pueblos y lugares del sur y sur-oriente de Bogotá (Zambrano et al., 2002).

Además, las características morfológicas y naturales de Usaquén marcaban un distanciamiento con las tierras áridas del sur y noroccidentales de la ciudad, por lo cual las tierras verdes del norte se convirtieron en los nuevos sitios de asentamiento de las élites capitalistas, que provenían, principalmente, desde Chapinero ${ }^{8}$ (ibídem, 2002).

Esta movilidad de las élites se produce como parte de un ejercicio de distinción y estratificación ya que en la Bogotá de principios del siglo XX, las diferentes clases y estratos convivían en los mismos territorios; adicional a ello, se observa la incapacidad del gobierno de la ciudad de vencer las condiciones higiénicas contrarias a la salud, la calidad del suministro de agua, la inexistencia del alcantarillado cubierto, la ausencia de regulación y control sobre la disposición de los desechos. Todos estos factores contribuyeron "para que las élites buscaran un entorno que correspondieran a su capacidad económica" (ibídem, p. 202).

Además, estos terrenos se habían convertido en lugares privilegiados para veranear, lo que reforzó el desplazamiento de las élites a estos sitios del norte (ibídem).

El proyecto de construir el Ferrocarril del Norte, cuyo fin principal era conectar a Bogotá con Venezuela, permitió la consolidación de una ruta regional que llegaba hasta Chiquinquirá, pasando por Usaquén y Zipaquirá (ibídem, p. 231). Lo que fortaleció la importancia de las tierras de Usaquén para la consolidación de la ciudad.

En el caso específico de El Codito, la Hacienda significó el inicio del proceso de poblamiento del territorio, en forma de la explotación de canteras y, a la par, de la toma de tierras. La siguiente sección se enfocará en estos dos procesos distintos pero consolidantes de la realidad del sector.

8 Chapinero, a través de los años, ha sido el barrio receptor de las élites políticas y económicas de la ciudad. Sin embargo, desde los años setenta su transformación ha llevado a que sea reconocido principalmente como un barrio de residencia estudiantil y de población LGBTI. 


\section{Las canteras y los primeros asentamientos}

Hoy día, el sector El Codito está compuesto por los barrios: Horizontes, Mirador del Norte, Lomitas, Buenavista I y II, Llanurita I y II, El Codito, Altos de Serrezuela, Vecinos de la Capilla, Mirador del Norte parte alta, Balcones de Vistahermosa, Nuevo Horizonte, Las Mercedes, Chaparral, Estrellita del Norte y La Franja; esta difuminación territorial puede tener su causa en el proceso histórico de conformación territorial y espacial que se ha desarrollado en El Codito.

Es por ello que los próximos párrafos buscarán dilucidar los elementos, realidades y sucesos que han marcado, a través de los años, a El Codito, desde sus inicios hasta lo que en la actualidad se reconoce.

Históricamente se evidencia en la consolidación de la ciudad es, por un lado, su expansión territorial sin afectación de los humedales del norte y occidente y, por otro lado, la ocupación de las zonas altas de ladera a lo largo de las montañas limítrofes del oriente de Bogotá, como sitio para extraer materias primas necesarias para su construcción (ibídem, 2002).

Entonces, reviste especial importancia lo que anteriormente se había mencionado sobre la instalación y funcionamiento de sitios de explotación minera sobre los cerros orientales de Bogotá, que para nuestro caso son las ubicadas al norte de la ciudad.

En efecto, Zambrano (2002) identifica la existencia, desde el siglo XVII, de una mita urbana ${ }^{9}$ ubicada en el resguardo de Usaquén. Este hallazgo indica que desde tiempos coloniales los cerros tutelares de la ciudad de Bogotá eran reserva permanente de recursos naturales y minerales.

De acuerdo con la reconstrucción espacial del resguardo, se evidencia que las canteras coloniales son las mismas que se explotaron en el siglo XX, teniendo en cuenta que el resguardo comprendía los límites de la calle 100 al sur de la localidad y la calle 170 al extremo norte (ibídem, 2002). Para

9 La mita urbana de Santafé fue una forma laboral que se impuso en 1580. Consistía en que las poblaciones cercanas a Santafé estaban obligadas a enviar la población aborigen para que trabajara en las obras públicas y en otro tipo de trabajo pagos. Además, existieron otras mitas como la de minas y la leñera, en las cuales participó la población aborigen de Usaquén. (Zambrano et al., 2002, p. 137) 
el sector El Codito estos sitios denominados coloquialmente como "canteras" fueron los escenarios iniciales en los que se empezó el asentamiento poblacional sobre el territorio.

La principal razón de este hecho fue la llegada de familias provenientes principalmente de Tolima, Boyacá y Cundinamarca, quienes, desplazadas por la situación de violencia y las pocas oportunidades de generación de ingresos en las áreas rurales, buscaban mejorar su situación de empleo y seguridad.

A pesar de que el sector El Codito se ubica desde la calle 174, lo que nos lleva a concluir, de acuerdo con los hallazgos de Zambrano, la inexistencia de canteras coloniales, sí se conoce de barrios que fueron, en un momento de la historia del territorio, sitios de extracción de recursos naturales y minerales. En la zona, el ejemplo más representativo es el barrio que lleva su mismo nombre, El Codito.

Este barrio está ubicado en el extremo sur del sector (calle 174); los primeros habitantes llegaron al territorio en busca de una fuente de ingresos estable que les permitiera cumplir el sueño citadino. Esta fuente de ingresos fue la explotación de canteras, que no solo significó un espacio para ejercer la actividad laboral, sino además, un sitio de asentamiento, de generación de arraigo y comunidad (Gualteros \& Londoño, 2006).

Un elemento destacable en el proceso reciente de urbanización es que, por su posición geográfica, el sector El Codito sirvió para forjar lo que Zambrano (2002) denomina la ciudad tentacular: tipo de ciudad que se expande y densifica en los bordes de los caminos, avenidas y calles principales. ${ }^{10}$

El ensanche de la ciudad se fue dando de modo tal que no obedeció a un proceso planeado de ordenamiento territorial ejecutado por inversiones privadas o por la intervención directa del Estado, sino al asentamiento progresivo de familias en antiguas parcelas y haciendas ubicadas en el norte, sur y occidente de la ciudad (ibídem, 2002). La forma de urbanización

10 Causa especial atención que la ciudad reticular en su dependencia a las vías de acceso y comunicación de la ciudad pudo aumentar el interés de explotar los recursos mineros de las montañas tutelares de Bogotá, cuestión que se señala para investigaciones posteriores ya que desbordan el objetivo del presente trabajo. 
consistía en la adquisición y cesión de predios del dueño de los terrenos circundantes a la cantera, para que allí se asentaran los trabajadores de las canteras y sus familias.

Precisamente, este es el caso del barrio El Codito ya que una parte del barrio pertenecía a la familia Gaviria Valenzuela quienes, al trascurrir los días y la llegada de nuevos pobladores, decidieron vender esos terrenos para urbanizarlos (El Tiempo, 2011).

En la mayoría de los casos, las familias trabajaban para los dueños de las canteras, quienes les proveían, en algunos casos, la prestación de algunos servicios públicos. La llegada de una mayor cantidad de familias a lo que anteriormente eran terrenos aptos para la agricultura y ganadería condujo a la transformación de ese territorio a sitios de asentamiento humanos; razón por la cual "el sector pasó, poco a poco, de ser una zona rural a una zona urbana” (El Tiempo, 2011), por lo menos en su concepción territorial.

\section{La venta de lotes y la toma de tierras}

La inserción informal del sector El Codito a la realidad de la urbe capitalina y las dinámicas que ella produce se evidencian en esta etapa definitiva de la consolidación territorial y espacial del sector de las ventas de lotes y las ocupaciones informales.

Este momento de urbanización y conformación del sector se genera a partir de la acelerada oferta de tierras relativamente baratas, en el norte de la ciudad.

Esta oferta respondía al incremento acelerado de la población bogotana ${ }^{11}$ que, dado a la inflexibilidad de la oferta en vivienda por parte de los constructores de la capital, se asentaba de forma descontrolada en los barrios marginales, subnormales o informales, con lo que accedían a un proceso de normalización y legalización producto de la mediación de políticos inescrupulosos y clientelistas (Zambrano et al., 2002).

11 El incremento poblacional fue producto de diversos factores: el aumento de las tasas de natalidad, el decrecimiento de la tasa de mortalidad, y los desplazamientos generados por la violencia rural y las pocas oportunidades de subsistencia. 
De esto último se desprenden las diferencias en los procesos de urbanización en el norte de la ciudad, cuyo principal componente fue la subdivisión de haciendas pero por empresarios ilegales y legales de tierras; esto caracteriza al norte de Bogotá, en la medida en que fueron los propietarios de las haciendas quienes definieron la oferta de tierra para la construcción de los nuevos asentamientos (ibídem, 2002).

En efecto, este fenómeno obedeció a la subdivisión o parcelación de las haciendas, que para el caso de Usaquén, la mayoría fueron producidas por los propietarios de las mismas (ibídem, 2002).

Precisamente, Zambrano (2002) expone como característica en el proceso de construcción de los nuevos asentamientos, de los cuales los barrios de El Codito no son la excepción, la carencia en el seguimiento de normas urbanísticas, cuya evidencia fáctica se observa en la inexistencia de espacios públicos —en especial: parques, el trazado de calles y la instalación de redes de servicio público-.

Aquellas personas que tenían las posibilidades económicas de comprar una subdivisión de la hacienda — las haciendas eran divididas en lotes de seis metros de frente por doce metros de fondo cada uno--, dado a que la oferta en construcción era tan precaria, debían autoconstruir sus viviendas, de este modo se forjaron lo que hoy se conocen como barrios informales. ${ }^{12}$ De hecho, "los inmigrantes, que habrían llegado a vivir en pequeñas piezas hasta haber acumulado ahorros suficientes para acceder a una casa propia, compraban estos lotes a plazos y en ellos construían poco a poco sus casas" (ibídem, pp. 259-260).

Ahora bien, el proceso de urbanización también estuvo sujeto a los pleitos que llegaron a tener estos inmuebles parcelados dado que, y específicamente en El Codito, la posibilidad de los asentamientos se dio por la conflictiva situación jurídica de los terrenos. En palabras de Ángel y

\footnotetext{
12 Alrededor de este término se ha discutido con gran amplitud sobre la naturaleza y forma de designar a los barrios que han surgido a partir de procesos de autoconstrucción. Ejemplos de designación: barrios de invasión, barrios de recuperación de tierras, barrios informales, barrios ilegales, cinturones de miseria, barrios de pobres, etcétera. A nuestro entender algunos de estos términos obedecen a denominaciones ideológicas o peyorativas o legalistas, por lo cual el autor prescindirá la utilización de los mismos.
} 
Leguizamón (1999, p. 83) "esos terrenos se encontraban en pleito, pues los propietarios dejaron cuidando el terreno a unas familias hacía más de veinte años, a quienes no se les pagó sueldo ni prestaciones. Por ese motivo tomaron la determinación de ceder lo que ellos consideraban su posesión a familias que no tuvieran techo con la asesoría de Provivienda para que defendiera esos derechos".

A medida que el sector se convertía en receptor de familias y nuevos pobladores, las demandas de los nuevos y viejos habitantes se incrementaban. Ello condujo a que los habitantes del territorio se vieran en la obligación de generar alianzas y procesos de colectividad unos con otros: "Poco a poco empezaron a llegar más personas a habitar El Codito y se vio la necesidad de organizarse" (Gualteros \& Londoño, 2006, p. 19).

Aunque la anterior cita hace referencia al barrio El Codito, existe un elemento compartido por los barrios del sector: el llamado a la unidad por la reivindicación del derecho a la vivienda. Ya sea por el acceso a los servicios públicos domiciliarios o por el derecho a la propiedad sobre la vivienda. Zambrano expone esta idea de la siguiente manera:

De pronto queda atrás, apenas como parte de un pasado — para algunos desconocido-, el sentimiento de solidaridad que llevaba a la organización de una comunidad en torno a la lucha de unos derechos que, debido a sus necesidades, estado de marginalidad, o el abuso de urbanizadores le fueron negados (el agua, la electricidad, el teléfono, la recolección de basuras...) (2002, p. 281).

En efecto, la participación de los habitantes del sector coadyuvó a la conformación de los barrios "porque tal vez si mucha gente no se hubiera unido, este barrio no sería el que es ahora. Eran personas que luchaban por sacar este barrio adelante a pesar de los recursos y servicios que tenían" (Alba, A. et al., 2007, p. 17).

La defensa de estos nuevos asentamientos fueron apoyados por dos actores claves, ya sea para el momento de confrontación y lucha por el derecho a la vivienda o para la legalización y escrituración de las viviendas y la iniciación de nuevos procesos de trabajo colectivo en el sector. 
De este modo, el promotor de la toma de tierras, quien en años siguientes asumiría el proceso de escrituración y legalización de las tierras y subsecuentemente de las viviendas (recuperadas o tomadas) en El Codito, es la Central Nacional Provivienda (Cenaprov).

Cenaprov, perteneciente al Partido Comunista Colombiano (PCC), ${ }^{13}$ ha acompañado desde los años sesenta del siglo pasado los procesos de recuperación de tierras a lo largo y ancho del territorio colombiano. Así, el acompañamiento y la dirección en estos procesos se evidencian en departamentos como Cundinamarca, Tolima, Valle, Santander, Meta, Huila, Cundinamarca, entre otros.

En sus inicios, Provivienda se dedicó a organizar a los diferentes inquilinos de la ciudad de Cali, para realizar acciones combativas en procura de la adjudicación de lotes cuyo uso fuera de vivienda. Estas acciones se ejercían a partir de movilizaciones masivas e ilegales. Desde los años cuarenta, concomitante al nacimiento de los comités de Provivienda, se fijaron los principales objetivos de la asociación: la toma de tierras y solucionar el problema de vivienda (Salas, P. A. 1998).

En este primer momento, el ideario que guiaba el accionar de Provivienda, que para el año 1944 se constituía como Federación de Comités, era el de unificar "las acciones de los inquilinos para hacerle frente a la reacción del gobierno, la oligarquía y los terratenientes urbanos" (ibídem, 20).

Para el año 1959 se fundó Provivienda seccional Bogotá. El objetivo principal en Bogotá era "organizar a los inquilinos, defenderlos en todos los aspectos y conseguir vivienda por cualquier medio" (ibídem, 21). En esos años, se buscó obtener la personería jurídica, lo que se logró con el cambio de nombre de la organización, que pasó a ser llamada Cenaprov, tal como se conoce actualmente.

A pesar de que la organización promoviera la toma de las tierras, se mantenía un criterio legalista de respeto por el derecho a la propiedad

13 Hay algunas personas que ubican a Cenaprov como parte de la desaparecida Unión Patriótica (UP). La UP era un partido político de izquierda y centro izquierda cuyo origen se sitúa en la década de los ochenta como resultado del proceso de paz entre el gobierno del ex presidente Betancur y distintos grupos de izquierda democrática y en armas; el Partido Comunista Colombiano hizo parte de esta iniciativa política que sufrió su exterminio en años posteriores. 
privada (ibídem, 23). Fue por ello que la mirada se tenía sobre los suelos ociosos, improductivos o terrenos ejidos.

Un primer trabajo que se tuvo que realizar en Bogotá fue el de identificar ese tipo de terrenos; por lo cual, se definieron unas comisiones que se dedicaron a investigar y localizar estos terrenos o aquellos que tuvieran problemas jurídicos (Salas, P. A. 1998). En Bogotá, aparte de los barrios del sector El Codito, ${ }^{14}$ se encuentra el barrio Policarpa Salavarrieta como el referente más utilizado para ejemplificar el trabajo de la Central.

La defensa evidenciada en el barrio Policarpa sirvió como ejemplo para ser reproducido en los distintos frentes de resistencia y lucha, que se han venido gestando desde ese entonces.

La añoranza de ser propietario de un pedazo de tierra en el que las familias pudieran construir sus viviendas, educar sus hijos, verlos crecer y pasar los años de vejez en algo que fuera propio se percibía como un sueño inalcanzable, debido a las limitadas posibilidades económicas y financieras de la mayoría. Por ello, al escuchar sobre los terrenos que se invadían y de las posibilidades reales de conseguir algo propio, no dudaban ni un segundo en acercarse y averiguar sobre el proceso para adquirir un lote.

En ocasiones, no solo era la añoranza de tener algo propio, sino la reivindicación del derecho a vivir dignamente. Derecho lesionado por la falta de programas estatales que solucionaran la situación de vivienda para las familias de desplazados por la violencia y la pobreza rural. Asimismo, la consolidación del modelo capitalista en la ciudad de Bogotá produjo el incremento de mano de obra de bajo costo y de ejércitos de reserva para los procesos de expansión productiva.

La estrategia de toma de tierras consistía en que la Central conformaba un grupo que se encargaba de organizar a la población deseosa de adquirir su vivienda; de este modo, estas personas ayudaban a "organizar las casitas de cartón. Me acuerdo tanto que se hacía la casita de tres por tres o de tres por cuatro, más o menos, en un sitio cercano a la invasión y

14 Se tiene certeza que solo dos barrios del sector obedecieron a dinámicas distintas a la toma o recuperación de tierras; estos barrios son El Codito y Horizontes. Los demás barrios del sector estuvieron influenciados de manera directa o indirecta por Cenaprov, ya sea en la toma o en la incitación y defensa de la tierra. 
de ahí la llevaban y la colocaban en el lote ya armada, y se formaba de esta manera, la invasión de un momento a otro" (Lombana, 2011).

Así, la construcción espontánea de los barrios se consolidaba al aparecer, de un momento a otro, viviendas en un terreno que el día anterior parecía desocupado. Esta estrategia podía obedecer a una respuesta ante la eventual acción de los agentes policivos y militares del Estado, que debían actuar ante los emergentes procesos de invasión, recuperación o toma de tierras.

Es decir, existiendo la construcción asentada en el territorio, ahora ocupado y construido, se hacía más difícil la expulsión y consecuente demolición de las viviendas, pues aunque estas casas fueran construidas de un material no muy resistente, se requería otro tipo de maquinaria para su destrucción.

Por ello, había quienes asumían la confrontación directa y se enfrentaban al poder militar del Estado, mientras que otros, "aprovechando el bochinche", se apresuraban a terminar el traslado y la edificación de las viviendas (ibídem, 2011).

De igual forma, parte del problema actual que adolecen estos barrios es su preponderancia en la planeación estratégica para ocupar el territorio pero la carencia en planeación urbana; cuestión recurrente en los dictámenes de la tecnocracia estatal de carácter negativo para intervenir o prestar los diversos servicios públicos domiciliarios. Bien lo expresa uno de los líderes de las tomas de tierras de Cenaprov "yo sí sé que cuando estábamos (...) llevando las casitas allá y poniéndolas en posición, [era] en forma desorganizada, porque una invasión es así. A uno lo que le interesa es ubicar y después mira la organización y planifica, porque repito, el deseo es enorme de hacer la casita y colocarla. Eso hizo que se presentara cierta discusión entre los mismos invasores de querer fomentar la discordia por la ubicación" (ibídem).

Estas discordias no solo moldearon barrios con limitaciones en la accesibilidad y movilidad, sino que pudieron ser constructoras de una estratificación social al interior de estos territorios. Ya sea entre barrios, familias o vecinos. Esta estrategia no evitó la confrontación con las fuerzas estatales y en medio del jolgorio y la algarabía, la fuerza pública hacía presencia para 
desalojar a los nuevos ocupantes del territorio, utilizando cualquier medio. Este accionar, en la mayoría de los casos, producía confrontación directa mediada por la violencia entre los nuevos ocupantes, los organizadores de la toma y los agentes estatales ${ }^{15}$ (ibídem, 2011).

Actualmente, Cenaprov no solo asesora jurídicamente la escrituración y legalización de viviendas, también se dedica a la promoción y construcción de viviendas: "hemos tenido varias experiencias. Inicialmente, se ha comenzado por la compra de terrenos, la adecuación con las obras de urbanismo y la construcción por el sistema de autoconstrucción y de vivienda progresiva. En la actualidad ya tenemos la oportunidad de entregar multifamiliares, es un avance que Cenaprov no había explorado" (Lombana, 2012).

En conclusión, Cenaprov se ha consolidado como una organización que busca solucionar el problema del acceso a la vivienda, siguiendo, en la mayoría de los casos, la vía de la autogestión (ibídem, 2012). Por ello, los Planes de Ordenamiento Territorial, la exigencia de una reforma urbana integral y la lucha por la ciudad democrática e incluyente son las directrices que conducen el devenir de la organización (Valdivieso, 2011).

Las tomas de tierras más representativas y recordadas en el sector fueron las de los barrios Chaparral y Buenavista sectores I y II.

En efecto, el barrio Buenavista era un proyecto de construcción urbana que podría denominarse como multifamiliar y su planeación se ubica en el año 1954. Sin embargo, la posibilidad de construcción se vio afectada debido a que recayó sobre ella un embargo. Esto produjo que alrededor de 30 lotes fueran ocupados por sus compradores, asentándose en el territorio de acuerdo a las diferentes manzanas que componían el proyecto de la urbanización (Ángel \& Leguizamón, 1999).

El resto del terreno que no fue ocupado, lo compró una persona que dispuso el uso del suelo al cultivo de: maíz, arveja, calabazas y hortalizas; en otro sector del mismo terreno se cuidaban vacas, ovejas, gallinas, burros y

\footnotetext{
15 Se tiene conocimiento que para la defensa del barrio Policarpa se registraron seis muertos. No se tiene conocimiento si algo similar pudo haber pasado en El Codito.
} 
marranos. Esto último produjo la pérdida de los linderos y mojones de los lotes (ibídem, 1999).

Las personas interesadas en participar en el proceso de adquisición de una vivienda o un lote de Cenaprov debían participar en un curso de 20 horas. El curso tenía como objetivo dictar unos módulos sobre convivencia entre vecinos y solidaridad. Al finalizar las 20 horas, los participantes se hacían acreedores del carnet de afiliación a la organización (ibídem, 1999).

Otro requisito para asegurarse un lote en el sector era firmar y registrar un documento de arrendamiento, en el que se certificaba como arrendador a Provivienda. Según Ángel y Leguizamón (1999) el contenido del contrato era ficticio y se constituía como medio de protección de las familias ante la inquisición de las autoridades.

El proceso de invasión tenía distintas fases que buscaban evitar un posible desalojo por parte de las autoridades policivas y militares del Estado.

En una primera fase, las familias llegaban a unas casetas hechas con polisombra en las que se debía mantener las medidas de tres por tres metros y cumplir con algunas funciones de seguridad para evitar que personas ajenas a la organización se apropiaran de los terrenos o provocaran un incendio para llamar la atención de las autoridades distritales (ibídem).

La estrategia para cercar el lote consistía en que las primeras familias se debían instalar sobre sus límites; esto para proteger y controlar la invasión. Esta práctica se desarrolló hasta mayo de 1983, cuando al instalarse 150 familias alrededor del lote, se suspendió el ingreso de más familias (ibídem).

En el momento en el que se logró consolidar la invasión, Provivienda contrató el loteo, cuestión que se hizo con amplia dificultad dado que se habían consolidado vías vehiculares y peatonales. La asignación de lotes se realizaba por sorteo; claro está que las primeras diez familias que habían llegado al sector, se les permitió escoger su lote. De igual forma, aquellas que siendo residentes del sector estuvieran interesados en la asignación de un lote comercial, solo debían pagar $\$ 50000$ de más, los cuales podían pagarse por cuotas (ibídem).

La entrega se completaba con el pago de $\$ 200$. El primero de enero de 1984 se inició el proceso de entrega de lotes. La construcción de las vi- 
viendas estaba condicionada al pago de $\$ 700$ por el plano de construcción. No obstante, y como lo expresan Ángel y Leguizamón (1999), la mayoría de las personas hicieron caso omiso a los planos y construyeron de acuerdo a lo que mejor les parecía, siempre permaneciendo dentro de los límites de los lotes.

Según distintos relatos, el sentido comunitario se enarbolaba cuando algún vecino debía echar la plancha en la vivienda. Más bien, este suceso colectivo se convertía en una fiesta y no en una acción comunitaria.

Se hacía un comité de más de quince obreros a los cuales no se les pagaba, pero se les daba buena comida. Con quince o veinte días de anterioridad se ponía a fermentar la chicha. El día anterior varias vecinas se atareaban pelando un bulto de papa y condimentando la carne para el día siguiente [...] En el transcurso del trabajo se tomaba chicha y cerveza en abundancia. Claro que unos iban a trabajar y otros a tragar [...] En caso de faltar comida y bebida se iban y dejaban el trabajo tirado (ibídem, 1999, p. 95).

El otro actor externo que cumplió un papel protagónico pero menos espectacular que Cenaprov fue el Instituto de Misioneras Seculares (IMS). Este era un grupo de mujeres misioneras que se insertaron en la realidad del sector en el año de 1989 y que les permitió compartir la toma de lo que hoy es el barrio Chaparral.

Encontramos a la gente en esa lucha por su tierra, cosa que en ese momento era muy importante. Las recuperaciones de tierra nos llamaban la atención. iCómo la gente luchaba por defender sus derechos! Entonces eso también nos atrajo [...] Las mujeres eran las cabezas, las que habían luchado por la tierra, las que habían puesto el pecho a la policía. Y como nosotras también queríamos hacer un trabajo con mujeres populares entonces eso nos llamó mucho la atención (Alba, A. et al., 2007, p. 20).

En el momento en el que las misioneras se instalaron en el barrio Horizontes, comenzaron un trabajo principalmente con mujeres; realizaron 
acompañamiento a las familias, promovieron la generación de herramientas solidarias para la subsistencia, facilitaron la apertura de espacios para educación informal: dictaron cursos de sexualidad y planificación familiar, confecciones y peluquería (Alba, A. et al., 2007, p. 21).

El trabajo realizado por estos dos actores fue determinante en la consolidación de varios barrios del sector. Para Alba (2007), barrios como El Codito y Horizontes se vieron influenciados por el componente religioso en la consolidación de elementos comunitarios, las formas de expresión y participación colectiva y las maneras de organización. Por el contrario, los barrios Chaparral y Buenavista sectores I y II tuvieron fuerte influencia de partidos y movimientos políticos de todas las tendencias.

Precisamente, el trabajo de estos dos actores tuvo su punto culmen en la consolidación del barrio Chaparral. A comienzos de los años ochenta una familia vigilaba el terreno que se convertiría en este barrio, aunque existía certeza del dueño del predio, se comenzó el poblamiento de los terrenos deshabitados con la avenencia de la familia que los cuidaba. Para 1984, había unas diez familias asentadas en este territorio (Alfonso, O., Noriko, A. \& Jaramillo, A., 1997).

En esa época aparece un primer reclamo sobre la propiedad. Ante este hecho los ocupantes buscaron la ayuda de Provivienda. La respuesta de la Central fue de apoyo, por lo cual se decide la extensión del asentamiento y la organización de la junta de Provivienda en el barrio. Al finalizar el año 1985, el número de familias ascendía a 86.

La mayoría de los primeros ocupantes eran desplazados por la violencia del municipio de Chaparral, Tolima. Por ello el nombre del barrio. Los terrenos se tomaron aún con varios intentos de la fuerza pública por desalojarlos y en otros intentos, cuando las familias ya se habían instalado, fueron rechazados por los pobladores del barrio junto a Provivienda y otras organizaciones viviendistas.

La historia de Chaparral fue una continuación del proceso que ya tenía iniciado Provivienda con los barrios Buenavista — sectores I y II—y que sirvieron para consolidar la presencia de la Central de Vivienda en el sector.

En el año de 1992, las hermanas del Instituto de Misioneras Seculares se trasladaron a vivir al barrio Horizontes que ya se había conformado y 
se dieron a la tarea de seguir organizando grupos comunitarios, la idea era trabajar con la población más vulnerable del sector que para entonces eran los recién instalados habitantes de Chaparral.

El trabajo en este último barrio consistió en hacer acompañamiento a las familias y generar mecanismos solidarios de subsistencia y educación informal.

No obstante, el trabajo sufrió de un sinnúmero de dificultades, principalmente por las confrontaciones con Provivienda como ala social del Partido Comunista Colombiano. Esta presencia de partidos políticos tradicionales y de izquierda supuso un conflicto por el control de la población, quien alimentaría los cuadros clientelistas de los políticos personalistastradicionales, y por el control sobre los bienes y recursos públicos (Alba, et al., 2007).

Precisamente, la escalada de violencia que rodeaba la década de 1980 al país, la descomposición política, económica y social, las pujas político partidistas, la corrupción reinante a nivel social y estatal y la clandestinidad obliterada de la izquierda colombiana tuvieron repercusiones directas en las diferentes regiones y localidades, de las cuales El Codito no fue la excepción. Así, Cenaprov y el grupo de misioneras se vieron envueltos en una dinámica de confrontación y choque en los albores del cambio constitucional de 1991. Esta confrontación tuvo sus orígenes en la ruptura social impuesta por la realidad política. Así fue como el barrio se encontraba dividido en dos bandos.

Por una parte, las (personas) que pertenecían a la Junta de Acción Comunal y por otro lado, las que eran militantes de la Central Provivienda [...] Un grupo de personas hizo contacto con las JAC de barrios vecinos como: Horizontes, El Codito, San Antonio, Verbenal. Ellos y ellas les ofrecieron su apoyo poniéndolos en contacto con el concejal Jorge $\mathrm{Mu}$ ñoz Pinzón. Con su ayuda se conformó un comité pro-junta encargado de la conformación de la JAC. Cuando los comunistas y su junta directiva se enteraron de eso se formó la de Troya y empezaron las agresiones verbales y los insultos por parlante (Alba, et al., 2007, p. 27). 
Las manifestaciones violentas e insultantes se presentaban de diversas formas, con frecuencia se utilizaba el escenario de la asamblea general para persuadir a la comunidad de desistir de la idea de establecer la JAC, asî como para convocar a los habitantes para resistir ante la llegada de políticos oportunistas.

Algunos relatos implican la consecución de espacios comunitarios a la relación que se tenía con políticos tradicionales. Alba (2007) señala la gestión que realizó Hernando Durán Dusán, quien fuera jefe político del partido Liberal y alcalde mayor de Bogotá entre 1978-1982, para que se firmara un convenio con el Centro Comunitario Simón Bolívar Servitá para el funcionamiento de la Casa Vecinal Horizontes.

Así, se puede argumentar que la lucha en el sector no se limitó al acceso de la vivienda; según algunos relatos, los espacios comunales también fueron fruto de la confrontación directa con los agentes del Estado.

Un ejemplo de esta defensa por los espacios comunales fue el caso del barrio Horizontes:

(...) la comunidad vio la necesidad de conseguir un espacio donde reunirse, es por eso que, liderados por la Junta de Acción Comunal, 90 familias se organizaron y se tomaron el 20 de julio de 1980 el lote para el salón comunal [...] la cita fue a las cuatro de la mañana y cada uno llevaba lo que podía: la Junta recogió una cuota para comprar la tela asfáltica y unos palos, se montó como un cabildo y la consigna era que de ahí no nos movían (Gualteros \& Londoño, 2006, p. 11).

Otro ejemplo significativo fue la toma del lote del colegio Nuevo Horizontes (Sede C), que contó con la participación de un sinnúmero de mujeres, niños y niñas, lo que logró la entrega del lote a la comunidad por parte del dueño (señor Cristancho).

Un espacio de grata recordación para los habitantes de los barrios El Codito y Horizontes fue la apropiación del lote en el que actualmente está construida la Casa Vecinal Horizontes. Esta Casa nace de la necesidad de establecer un sitio donde los padres y madres de familia, en momentos de jornada laboral, pudieran dejar sus hijos e hijas al cuidado de adultos 
responsables. El proceso de construcción de la Casa Vecinal implicó una negociación con entidades locales para acceder al terreno y la unidad de los habitantes del sector.

El sentido comunitario se evidenció en la labor que la Junta de Acción Comunal y los padres y madres interesados cumplieron:

[Ellos] compraron la casa prefabricada [...] La comunidad se dio a la tarea de sacar tierra para poder construir lo que es hoy el jardín. Las madres usuarias teníamos un día de trabajo voluntario obligatorio. Empezamos a trabajar en los estatutos y a hacer las vueltas respectivas. Estábamos pasando por una etapa muy importante donde entidades y personas querían colaborar (Alba, et al., 2007, p. 24).

Del mismo modo, los habitantes de los barrios de la parte baja del sector tuvieron que recurrir a soluciones comunitarias para solventar la carencia de instituciones educativas o la imposibilidad de inscribir a sus hijos e hijas en las instituciones de esta zona de Usaquén.

Sobre este último aspecto, se resalta que en los colegios de la parte baja de la séptima se rehusaban a recibir estudiantes de los barrios colindantes situados en la zona montañosa. La explicación proviene de la percepción e influencia de los vecinos del colegio quienes señalaban a los habitantes de los cerros como "invasores, comunistas, roñosos y patirrajados" (Ángel \& Leguizamón, 1999, p. 105).

Así, y ante la negativa de los otros padres y madres de familia y rectores de los colegios de Tibabitá — barrio en el que se situaban los colegios más cercanos a El Codito-, los habitantes del sector tuvieron que construir una escuela en el barrio. "Aportamos una cuota por familia y con otras actividades realizadas levantamos un aula. Solo se dictaba primero de primaria y los padres de familia pagábamos el sueldo de la profesora" (ibídem, p. 114).

Con el paso de los años, la Secretaría de Educación de Bogotá construyó una escuela que recibe alumnos desde transición hasta quinto de primaria y la sede de bachillerato, que se ubica en el mismo lugar donde se construyó el aula por parte de los residentes del sector, prepara a los futuros bachilleres en doble jornada. 
Aparte de estos casos, existen otros dos colegios distritales en el sector: el colegio Don Bosco III y el Friedrich Naumann. También se destaca la iniciativa privada del colegio anexo Santa Francisca Romana.

\section{Las primeras demandas: los servicios públicos}

En un primer momento y con la llegada de algunos pobladores, el acceso a los servicios públicos fue disímil; por un lado, los primeros habitantes de algunos barrios contaron con la fortuna del recurso natural o con la ayuda de algún vecino quien les facilitó el acceso al agua.

Este fue el caso del barrio El Codito que con la llegada de los primeros habitantes, el propietario de la finca vecina Carlos Medellín, quien era magistrado de la Corte Suprema de Justicia y cuyo deceso se produjo en la toma al Palacio de Justicia, hizo instalar la conexión de agua en las siete primeras viviendas precursoras del barrio (Gualteros \& Londoño, 2006).

Del mismo modo, los habitantes del sector contaron con aliados que facilitaron la gestión de servicios públicos para el sector. En el caso del acueducto,

(...) en marzo de 1982, el director de "urbanizaciones intervenidas" del Instituto de Crédito Territorial informa al Club Rotario que con la ayuda del Club y la acción Comunal han implantado en el barrio Horizontes la instalación de las líneas de agua con sus correspondientes motobombas y cuatro piletas. Para esa misma fecha se dio la primera cuota para la instalación eléctrica y el 16 de mayo de 1983, el Club Rotario nos dota al comité local de salud y al puesto de primeros auxilios de la Cruz Roja con los elementos necesarios para prestar un mejor servicio (ibídem, p. 25).

No obstante, otros habitantes no tuvieron la misma suerte. Los tomadores de tierra de Buenavista recién llegados al sector, buscaron el apoyo de los residentes de la antigua urbanización, cuyo asentamiento había sido construido en años anteriores a la ola de invasiones de Provivienda, para acceder al servicio del agua. Esta urbanización contaba con un tanque de 
almacenamiento de agua. Ángel y Leguizamón (1999, p. 87) recuerdan esta situación:

(...) fuimos allí para que nos vendieran un poco de agua, pero cual sería nuestra sorpresa, cuando una señora que nos atendió nos gritó: "iInvasores, ladrones, quién sabe qué clase de plaga serán o de dónde vendrán!" Edelmira, una señora que llegó antes que nosotros a la urbanización nos dijo: "no se metan con esa vieja que es muy mierda y no sirve para nada. Aquí el agua toca traerla de debajo de la séptima, vengan yo les presto un garrafón. Toca que compren sus garrafones, para que la traigan”.

Este corto relato demuestra las dificultades en la consolidación del sentir solidario y comunitario, a pesar de que los habitantes podían compartir elementos definitorios en la construcción del territorio.

Lo mismo ocurrió con los nuevos barrios, como el caso de Chaparral que en el año de 1986 los habitantes del barrio tuvieron que comprar un tanque de almacenamiento de agua, muy seguramente debido a las diferencias existentes con los habitantes de los otros barrios, teniendo que acordar con la empresa de acueducto y alcantarillado la provisión de agua por medio de carrotanques. Para que el servicio se prestara sin contratiempos, la comunidad se organizó para construir cuatro baños.

Esto demuestra las dificultades que los pobladores encontraron para generar lazos de solidaridad entre los vecinos de los distintos barrios, si se entiende que, en ocasiones, estos no superan la extensión de dos manzanas.

Además, se evidencian las fracturas en la construcción del capital social con las percepciones divisorias en cuanto a los derechos de dominio sobre los lotes y las viviendas. Así, "los barrios [...] como El Codito y Horizontes poseían sistema de bombeo y distribución en pilas, pero el problema era que nos discriminaban demasiado y no nos permitían tomar el líquido, porque decían que éramos unos invasores, comunistas y patirrajados" (ibídem, p. 105).

A pesar de que existían quebradas en las inmediaciones de los barrios del sector, estas solo servían como fuentes del recurso para algunos barrios. Este es el caso de la quebrada Sarauz que para Ángel y Leguizamón (1999) 
era acaparada por los habitantes del barrio El Codito. "Por allí ni nos asomábamos, porque nos corrían a piedra" (p. 106).

Otra de las quebradas que proveía de agua al sector era la Inmaculada; esta quedaba ubicada en la finca de la Matucana, parte alta del sector, ofrecía la facilidad de acceder al recurso natural del agua pero dificultaba el transporte del mismo.

Cobra vital importancia el transporte que prestaba servicio a las canteras del sector ya que se convirtieron en proveedores de los habitantes para descender de la Matucana con los bidones de agua. Esta situación generó acercamientos entre los volqueteros y los habitantes de El Codito y se estrecharon los vínculos de amistad y sentimentales (ibídem). No obstante, aquellos pobladores que no contaban con facilidades para subir hasta la Matucana, se veían obligados a bajar al barrio Tibabitá, lo que implicaba recorrer una distancia considerable y enfrentarse a una población que no contaba con los afectos ni elementos solidarios necesarios para compartir el vital líquido. De hecho, la fuente de Tibabitá duró poco dado a que los vecinos de ese barrio no permitieron que los habitantes del cerro tomaran el agua de allí (ibídem).

Con el paso de los años, los habitantes del sector comenzaron a idear otros medios más acordes con los tiempos para acceder al agua. Fue así como en 1984 los habitantes de Buenavista acordaron construir un acueducto, utilizando un tanque viejo que existía en la parte alta del barrio y con la consecuente inversión de las empresas de Acueducto y Alcantarillado y de Energía Eléctrica de Bogotá. Sin embargo, esta solución fue temporal debido a que las motobombas instaladas no daban abasto para la cantidad de demandantes y a que al cabo de un tiempo se las robaron (Ángel \& Leguizamón, 1999).

Con estas dificultades se tuvo que ingeniar un mecanismo que permitiera el acceso al agua de forma segura para todos. Por ello se hizo necesario racionar la prestación del servicio de agua al horario de cinco a siete de la mañana y la presentación de un carnet para controlar que todos tuvieran garantizado su derecho a este líquido (ibídem).

Esta nueva situación generó mayores conflictos ya que la mayoría de los pobladores se negaron a pagar la cuota de mantenimiento (fue ne- 
cesario contratar a un fontanero para evitar el daño progresivo de las motobombas); esos enfrentamientos produjeron la renuencia de las empresas de Acueducto y Alcantarillado y de Energía Eléctrica a seguir prestando el servicio (ibídem).

Durante el tiempo sin servicio de acueducto se utilizó el sistema de carrotanques enviados por la Empresa de Acueducto, para suplir esta necesidad. En 1987, la construcción definitiva del acueducto y del alcantarillado fue una realidad como consecuencia de la gestión de un concejal liberal, dos concejales con filiaciones de izquierda y un conservador (ibídem).

La evolución de la prestación de otros servicios públicos fue parecida a la del agua pero sin escenarios dramáticos. El servicio de energía eléctrica era tomado de forma ilegal desde la avenida séptima, lo cual generaba ciertos enfrentamientos con los residentes de barrios legalizados, quienes denunciaban la acción de robo a la policía (ibídem).

Pero los grandes contratiempos se produjeron cuando los residentes, en busca de mejorar la calidad de luz que recibían, comenzaron a conectarse directamente en las líneas principales que pasaban sobre la séptima. Estos conflictos fueron consecuencia de tomar la luz del cable que se conectaba a la línea principal. "Lo que se convirtió en un contrabando al contrabando" (ibídem, p. 110).

Igual que el acueducto y el alcantarillado, la Empresa de Energía Eléctrica comenzó la construcción de sus redes en el año 1987.

Para cocinar, los hogares utilizaban cocinol: este es un derivado del petróleo que se destina al consumo doméstico, su composición y textura se parece al de la gasolina pero se diferencia en su nivel de octanaje. Para adquirir el cocinol, las familias debían estar inscritas en los barrios que habitaban y, en el momento de compra, debían presentar el carnet que acreditaba su residencia y facilitaba el control sobre la provisión del combustible (ibídem).

Por el estado germinal de estos barrios, sus habitantes no contaban con los recursos necesarios para el almacenamiento y distribución de este combustible; por ello, debían recurrir a otros barrios para comprarlo. Sin embargo, las dificultades para conseguir un carnet y el preciado combustible en otro barrio fueron determinantes para que se gestara en el interior de la 
junta directiva la iniciativa de comprar un tanque de almacenamiento; la adquisición de un tanque viejo se hizo posible, pero nunca llegó el cocinol al sector (ibídem). Años después fue reemplazado por gas propano, lo que facilitó la cocción de alimentos y prescindió de la generación de demandas colectivas.

En cuanto a la instalación de las líneas telefónicas, se presentó una situación que terminó por favorecer a un grupo de personas cuyos afectos eran cercanos a Provivienda. Según lo relata Ángel y Leguizamón (1999, p. 113), “en 1991 Clara López Obregón, quien era alta funcionaria de la ETB y muy amiga del concejal Carlos Romero, consiguió que por la vía principal se instalara un tramo de red con capacidad para trescientas líneas. Esta red terminaba exactamente al pie de la oficina de la junta directiva y los únicos beneficiados fueron sus seguidores".

Este hecho fue causa de un rechazo generalizado de las JAC de Buenavista y Estrellita del Norte, que con la ayuda del concejal Jorge Muñoz, se reclamó vehementemente ante el gerente de la ETB. Un año después de la reclamación se instalaron las redes faltantes para aquellos hogares que así lo reclamaban (ibídem).

\section{A modo de conclusión. Nuevas y antiguas demandas: derechos reales, basuras e infraestructura}

Luego del recorrido realizado por la forma como se asentó la población en el sector y de presentar las luchas sociales por el derecho a la vivienda digna y el acceso a los servicios públicos, queda por señalar algunas situaciones actuales que tienen conexión directa con la ocupación histórica del territorio.

\section{Derechos reales: los procesos de escrituración y la legalidad de los barrios}

Como consecuencia del poblamiento del sector, un factor que ha marcado la personalidad de los habitantes de El Codito ha sido su renuencia a desalojar 
el territorio que habitan. En un buen número de ocasiones y bajo la argumentación técnica aunque no coherente ni consolidada de los gobiernos de la ciudad, se ha pretendido reubicar a los pobladores de estos barrios.

Lo que algunos diagnósticos estatales señalan es que debido a los procesos de autoconstrucción de las viviendas, la carencia en el seguimiento a las normas de construcción y a que el terreno sobre el que se asienta el sector fue zona de remoción en masa o de explotación de canteras, por preservar el derecho a la vida de los habitantes, se debe reubicar a un número indeterminado de personas.

Esta dificultad territorial sobre El Codito ha perpetuado una relación distante entre los habitantes del sector y las autoridades locales, especialmente los representantes directos de la Alcaldía Mayor de Bogotá, dado a que en reiteradas ocasiones se expresa la necesidad de iniciar un proceso de reubicación del sector.

Esta relación se profundiza ante la negativa o la imposibilidad de legalizar barrios sobre terrenos no aptos para la habitabilidad o subsistencia, cuestión que en reiteradas situaciones se debate al interior de los espacios comunitarios como respuesta a las demandas de los pobladores del sector.

Al mismo tiempo, los procesos de escrituración de las viviendas, especialmente de aquellas que hicieron parte de los procesos de autoconstrucción y toma de tierras, son dispendiosos en tiempos y recursos económicos. A pesar de que en algunos casos Provivienda continúa su labor en el sector sobre este tema, existen algunos abogados cuyas prácticas poco profesionales ayudan a perpetuar la situación incierta sobre la propiedad de los bienes ocupados.

Por si fuera poco, y ante la normatividad expuesta anteriormente y el vacío jurídico que existe sobre el tema, la incertidumbre se posa sobre los habitantes del sector al entender la imposibilidad administrativa existente para declarar la propiedad sobre estos bienes. El hecho que no se defina el límite de la reserva forestal sobre los cerros orientales de la ciudad es un impedimento para cualquier autoridad decidir sobre las personas y los bienes que actualmente se asientan sobre ellos. 


\section{Basuras e infraestructura}

Ahora bien, en los relatos y discursos de diferentes líderes y habitantes del sector, los temas de infraestructura y aseo cobran especial importancia en el momento de señalar los principales problemas de los barrios de El Codito ${ }^{16}$ (Mendoza \& Guevara, 2012, p. 224).

Así, lo que se observa es el problema de basuras e infraestructura cuya relación puede tener vínculo directo con la forma como estos barrios se han ido construyendo con el paso del tiempo.

Los problemas actuales relacionados con la infraestructura del sector se pueden señalar en: el mantenimiento de la malla vial; el acceso efectivo a los servicios públicos domiciliarios; la adecuación de los espacios públicos, especial atención deben tener los parques del sector; la adaptación de las escaleras y el mantenimiento de las existentes; así como la formulación de políticas y proyectos que permitan la verdadera inclusión espacial de los adultos mayores y de las personas en condición de discapacidad.

A pesar de que el sector se consolidó como una expansión de la ciudad reticular — modelo de ciudad que se expande en derredor de las avenidas principales de la ciudad_- las vías que comunican los barrios del sector con la ciudad no presentan un buen estado. A pesar de que se está realizando desde al año 2009 la construcción de la vía principal del sector, que para los propósitos expansivos de la ciudad facilita el transporte de los municipios orientales de Cundinamarca; no obstante, esta obra no permitirá el tráfico pesado que se proyecta con la realización del Plan Zonal de Expansión Norte, cuestión limitada por el espacio reducido existente entre los barrios que rodean la vía.

No obstante, el sector se ve beneficiado por la instalación de nuevas redes telefónicas y de acueducto y alcantarillado, con lo que se espera que se legalice la situación de muchos habitantes del sector, por lo menos en el tema de servicios públicos.

16 Se exceptúan los fenómenos de inseguridad reseñados en Mendoza y Guevara (2012) ya que estos no corresponden a la relación directa con el poblamiento del sector, sino a fenómenos que, en ocasiones, desbordan la propia esfera de la ciudad. 
Ahora bien, un elemento que dificulta la intervención en el tema de basuras y de infraestructura son las características propias del terreno en ladera. Estas condiciones determinan las dificultades para la movilidad, la planeación y el diseño de las vías, calles, andenes y escaleras.

Aunque este es un elemento a tener en cuenta, no se puede convertir en una excusa para la falta de coordinación y efectividad por parte de las instituciones estatales, las empresas prestadoras de servicios públicos y los pobladores del sector.

Especial mención se hace sobre estos últimos y sus representantes, como las JAC, ya que sobre ellos recae el proceso de desarrollo, por eso llama especial atención el hecho que estas ya no tienen el mismo compromiso y credibilidad, en parte debido a que las necesidades y los problemas no son los mismos que en los primeros años de los barrios y a que los líderes en las JAC no han hecho las mejores administraciones ni gestiones (Gualteros \& Londoño, 2006).

No se debe dejar de resaltar que la coyuntura sistémica debilita las visiones y los ánimos de las comunidades y actores sociales, para afrontar la realidad que se antepone a los ojos citadinos. Así como la evidencia del desgaste de los movimientos sociales en épocas neoliberales.

Nuestro contexto actual es de fragmentación territorial, económica, social, cultural y política. Este nuevo tiempo está marcado por el sentimiento de la crisis y la impotencia. Las formas de organización social anteriores ya no logran ser vehículos de expresión colectiva y autónoma de la población. Se trata de una crisis de sentido que toca las formas fundamentales de socialización. El ambiente general es de incertidumbre (Alba, A. et al., 2007, pp. 17-18).

Por ello la importancia de estudiar el territorio pero como forma de expresión de la comunidad, pues sin ella, las complejidades del desarrollo se acrecientan y se desplazan a la esfera del individuo. 


\section{Bibliografía}

Alba, A., Gualteros, E., Jiménez, C. \& Rodríguez, A. (2007). Sistematización de la experiencia de participación de la cooperativa Copevisa en la localidad de Usaquén (Bogotá, Colombia). Recuperado de www.alboan.org/archivos/595.pdf

Alcaldía Mayor de Bogotá. Departamento Administrativo de Acción Comunal. (1998). Bogotá, historia común. Trabajos ganadores segundo concurso de historias barriales y veredales. Bogotá: IDCT.

Alcaldía Mayor de Bogotá. (2006). Plan de Manejo Ambiental-Audiencia CAR. Bogotá: Autor.

Alfonso, O. Noriko, A. \& Jaramillo, A. (1997). Organización popular y Desarrollo urbano en Bogotá. Santafé de Bogotá: Universidad Externado de Colombia. Facultad de Economía.

Angel, L. \& Leguizamón, P. (1999). El ayer y hoy de Buenavista. En: González, B. Bogotá, historia común. Tomo III (pp. 78-129). Bogotá: Departamento Administrativo de Acción Comunal y Alcaldía Mayor de Santafé de Bogotá

Arango, C. (1981). Crónicas de la lucha por la vivienda en Colombia. Bogotá: Editorial Colombia Nueva.

Archila, M, Álvaro, D., García, M \& Prada, E. (2002). 25 años de luchas sociales en Colombia. 1975-2000. Bogotá: Centro de Investigación y Educación Popular (Cinep).

Bohórquez, I. A. (2008). La política pública para los cerros orientales de Bogotá. Territorios, (18-19), pp. 229-242.

Camargo, G. (2001). El proceso histórico y las perspectivas de ordenamiento de los cerros orientales de Bogotá D. C. Ambiente y Desarrollo, (9), pp. 119-136.

Camargo, G. (s. f.). Marco normativo de los Cerros Orientales de Bogotá. Recuperado de http://www.cerrosdebogota.org/joomla/images/stories/Historia/ marconormativo.pdf

Camargo, G. (s. f.). Historia pintoresca y las perspectivas de ordenamiento de los cerros orientales de Santa Fe de Bogotá. Recuperado de: http://www.cerrosdebogota.org/joomla/images/stories/Historia/historiacerrosdebogota.pdf 
Camargo, G. (2006) Una norma que nos permita ayudar a conservar los cerros orientales. Recuperado de: http://www.rds.org.co/aa/img_upload/aea709feb9d6e6499a219fa83c2c5451/Cerros_orientales.pdf

Ceballos, R. \& Olga, L. (2005). Vivienda social en Colombia. Una mirada desde su legislación 1918-2005 (1 $1^{a}$ ed.). Bogotá: Editorial Javeriana.

Central Nacional Provivienda. (1981). La unidad de acción y las organizaciones populares de vivienda. La vivienda popular hoy en Colombia (pp. 283294). Bogotá: Centro de Investigación y Educación Popular (Cinep), Foro Nacional por Colombia.

Congreso de la República de Colombia (1968). Ley 66 de 1968 "Por el cual se regulan las actividades de urbanización, construcción y crédito para la adquisición de viviendas y se determina su inspección y vigilancia”. Corporación Autónoma Regional de Cundinamarca-CAR (2006). Plan manejo de la reserva forestal protectora bosque oriental de Bogotá. (Documento técnico). Recuperado de http://www.car.gov.co/?idcategoria $=3812$

Diaz, L. (s. f.) Cerros de Bogotá iun espacio (e) en vía de extinción? Recuperado de http://chapineroverde.org/biblioteca/CERROS_ORIENTALES_CINEP.PDF

En El Codito los buenos somos más. (s. f.). En Periódico El Tiempo. Recuperado de http:/www.eltiempo.com/archivo/documento/CMS-10218044

Gualteros, S. \& Londoño, J. (2006). Caracterización de la unidad de planeación zonal (UPZ) Verbenal. Diplomado en control social. Bogotá.

Guillén, F. (1979). El poder político en Colombia. Bogotá: Punta de lanza.

Lombana, N. (2011). Barrio Policarpa Salavarrieta: 50 años de lucha, resistencia y dignidad. Recuperadado de http://www.pacocol.org/index. php?option $=$ com_content $\&$ task $=$ view $\&$ id $=7751$

Lombana, N. (2012). Cenaprov sí les cumple a los destechados colombianos. Recuperado de http://www.pacocol.org/index.php?option=com content\&task $=$ view \&id $=11990$

Mendoza, M. \& Guevara, J. (2012). Retos y avances de desarrollo local. Caso El Codito. Bogotá: Editorial Universidad del Rosario.

Mesa Ambiental de Cerros Orientales. (2008). Territorios Populares, Ambiente y Hábitat. Bogotá: Ediciones Gente Nueva.

Partido Comunista Colombiano (PCC). (2008). Historia del PCC 1930-2008 78 años de lucha. Recuperado de http://www.pacocol.org/index.php?option=com content\&task $=$ view $\&$ id $=334$ 
Personería de Bogotá. (2007). Cerros orientales. Desafío institucional. (Documento institucional). Bogotá.

Presidente de la República de Colombia. (1977). Resolución 0076 de 1977. "Por la cual se aprueba un Acuerdo de la Junta Directiva del Instituto Nacional de los Recursos Naturales Renovables y del Ambiente - Inderena-". Bogotá.

Primer inventario del D. E. 298 barrios fuera de Ley. (1975). El Tiempo, p. 7A.

Ramírez, J., Useche, I., Jiménez, F., Soto, P., Giraldo, F., Molina, H. et al. (1981). La vivienda popular hoy en Colombia. Bogotá: Centro de Investigación y Educación Popular (Cinep), Foro Nacional por Colombia.

Salas, P. A. (1998). Policarpa. En una noche amanecía un barrio. En: Salas, P. A. et al. Bogotá, historia común. Tomo II (pp. 19-94). Bogotá: Departamento Administrativo de Acción Comunal y Alcaldía Mayor de Santafé de Bogotá.

Torres, A. (2003). La ciudad en la sombra. Barrios y luchas populares en Bogotá. 1950-1977. Bogotá: Cinep.

Torres, A. (2007). Identidad y política de la acción colectiva. Organizaciones populares y luchas urbanas en Bogotá. 1980-2000. Bogotá: Universidad Pedagógica Nacional. (Colección Ciencias Sociales).

Torres, A., Mendoza, N., Barragán, D., Vargas, A., González, M., Avendaño, M. et al. (2003). Organizaciones populares, identidades colectivas y ciudadanía en Bogotá. Bogotá: Universidad Pedagógica Nacional. División de Gestión de Proyectos CiUP. Facultad de Humanidades, Departamento de Ciencias Sociales.

Torres, C. (2009). Ciudad informal colombiana. Barrios construidos por la gente. Bogotá: Universidad Nacional de Colombia. Sede Bogotá. Facultad de Artes. Maestría en Hábitat.

Torres Tovar, C. A. (2000). La ciudad, espacio de inclusión y exclusión. La ciudad: hábitat de diversidad y complejidad (pp. 318-332). Bogotá: Facultad de Artes. Universidad Nacional de Colombia.

Valdivieso, A. (2011). Con rotundo éxito se realizó la XxXI Asamblea nacional de Cenaprov. http://www.pacocol.org/index.php?option=com_ contentËtask $=$ view $\mathcal{E} i d=8553$

Zambrano, F., Castelblanco, C., Sánchez, L., Hoyos, J., Benninghoff, F., \& Ruíz, M. (2002). Comunidades y territorios. Reconstrucción histórica de Usaquén. Bogotá, Colombia: Panamericana. 


\title{
Adulto mayor y construcción de comunidad
}

\author{
Miguel Hernández García*
}

* Abogado y Politólogo por la Universidad Carlos III de Madrid; experto en Gestión y Prevención de Crisis Internacionales; master en Cooperación Internacional al Desarrollo y Ayuda Humanitaria, profesional Técnico de Proyectos. Correo electrónico: mhg.miguel@gmail.com 
Gracias a todas las personas que, compartiendo sus vidas con la comunidad, nos permiten alejarnos de la Historia Única.

La amplitud, la velocidad y, en varias ocasiones, la precariedad es lo que caracteriza a las "urbanizaciones aceleradas" que viven muchas de las grandes ciudades en los llamados países en desarrollo. En Bogotá, la construcción de elementos urbanos se ha sucedido a un ritmo muy acelerado, integrándose con el entorno natural de manera deficiente. Las carencias y los problemas que se deben atender y solucionar son muchos, entre ellos, en lo que atañe a la relación entre territorio y comunidad, el relativo a la integración de lo urbano y lo rural, dos realidades que en Colombia han venido confundiéndose muy rápidamente.

La capital está inmersa desde hace un tiempo relativamente prudente en un proceso de desarrollo cuyo impacto positivo ya se deja sentir, pero que no permite hablar aún con propiedad de una ciudad que humanice. Bogotá no escapa a la caracterización de "ciudad dual", aquella en donde abundan tanto barrios de lujo, acotados y seguros, como zonas de hacinamiento y concentración de pobreza. Muchas veces ambas situaciones coinciden en un mismo sector; en especial, es evidente y llamativa la desigualdad social a lo largo de todo el corredor oriental.

\section{La acción social de la Universidad del Rosario. Introducción al trabajo con adulto mayor en El Codito}

La esencia comunitaria de la ciudad está siendo eliminada del pensamiento y la sensibilidad humana (Edgar Morín, La vía para el futuro de la humanidad).

Como ya ha sido explicitado, la escasez de programas dirigidos a la población del sector de El Codito motiva y justifica la actuación de la Universidad del Rosario en la zona. Una vez creados los lazos de confianza que requiere el establecimiento de un trabajo eficaz y perdurable, y tomado el adulto mayor como punto de partida para el mismo, se ponen en marcha los programas productivos y de alfabetización, que buscan potenciar valores personales y comunitarios entre sus participantes. Paralelamente, se inicia una ar- 
dua pero interesante labor transversal de construcción y reconstrucción de la memoria histórica colectiva tendiente a fomentar el sentimiento de pertenencia y la participación comunitaria entre los vecinos y las vecinas del sector. Así, se vienen realizando una vez al mes encuentros de adultos mayores en los que, además de transmitir conocimientos y procurar la capacitación de los líderes y lideresas, se persigue lograr que sean las propias comunidades quienes asuman sus procesos de desarrollo e interlocución con las entidades públicas de gobierno y gestión social. Se trabaja el fortalecimiento de las organizaciones locales del sector y la creación de conciencia colectiva en lo que respecta al emprendimiento de procesos de desarrollo autónomos y sostenibles. ${ }^{1}$

La Universidad del Rosario mantiene desde el año 2009 una relación convencional con la Universidad Carlos III de Madrid por medio de la cual se establecen anualmente unos periodos de tres a seis meses durante los cuales estudiantes titulados en el Máster de Acción Solidaria Internacional de Europa, profesionales de la Agencia Española de Cooperación Internacional para el Desarrollo, le aportan a los distintos proyectos de la Universidad del Rosario. De esta manera, se pone en marcha una línea de investigación conjunta, en donde la "acción social rosarista" se enriquece con la internacionalización de sus actores. A continuación, se desarrolla ordenadamente el desempeño realizado a lo largo del segundo semestre de 2011 en relación al trabajo con el adulto mayor en la zona desde la perspectiva de terreno de uno de sus integrantes.

Los objetivos previstos, circunscritos en el marco de la continuación y profundización de las tareas de investigación social sobre comunidad y territorio en el sector, se plantean en términos de la dinamización de las actividades de la Red Adulto Mayor. Una de sus integrantes comparte la opinión que tiene del grupo: "Merece el respeto, porque somos personas que aportamos mucho a la sociedad, porque a nosotros nos ha tocado su-

\footnotetext{
Una cooperación eficaz requiere la apropiación de los beneficiarios y beneficiarias directos de las acciones de desarrollo, de sus efectos e impacto. Así, se hace especialmente necesario que la masa humana implicada en la cuestión conozca personalmente las necesidades, inquietudes y aspiraciones de la comunidad meta en donde se trabaje, y hasta que, de alguna manera, comparta o se implique en su realidad social.
} 
frir mucho. Hemos estado en las buenas y en las malas, y podemos aportar mucho a la juventud... darle mucho consejo". De esta manera, el acompañamiento en los procesos de desarrollo de la comunidad se desempeña con miras a fortalecer el trabajo colectivo y el liderazgo de la comunidad, además de apoyar al resto de componentes del proyecto general, en curso de ejecución, por parte de la acción social referida.

Para la realización de las metas planteadas se propusieron, previa documentación y puesta en contexto de la situación del sector y del trabajo hasta entonces adelantado, unas jornadas de comunicación, registro y análisis de información relevante sobre el mismo y la población objetivo de los procesos en desarrollo. Los barrios visitados fueron: El Mirador, El Codito, Serrezuela, Lomitas, Capilla y Horizontes. Esto es, en sucesivas visitas al sector, desde el acercamiento a la cotidianeidad de la vida en los barrios de la zona, y a partir del estudio e interpretación de su historia pasada, se ha tratado de ordenar y comprender las dinámicas que informan los usos, costumbres y modos de vida de las vecinas y los vecinos que los habitan.

Por otra parte, las actividades desarrolladas en el segundo semestre del año 2011, incluyeron la realización, transcripción, corrección y sistematización de entrevistas abiertas o semiestructuradas al grupo integrado por adultos mayores. En estas se estudiaron los momentos y motivos de la llegada al sector, las condiciones de habitabilidad, forma, obstáculos y facilidades con que se desarrollaron los procesos de asentamiento y ocupaciones laborales realizadas. Sobre lo anterior, se puso especial cuidado en las formas de relación entre los vecinos y las vecinas, de las familias que iban llegando al sector en los momentos en que se conformaron los barrios que lo integran, en los procesos de intercambio de experiencias, en las razones para decidir colaborar o no en los procesos comunitarios y en las diversas formas de comunicación entre estos.

Se estudiaron así, siempre desde el enfoque temporal comparativo (pasado, presente y visión de futuro) las relaciones de poder generadas en la zona, los elementos o lugares significativos de esta, la formación de sentido de pertenencia y de arraigo colectivo y de construcción y reconstrucción de comunidad entre sus habitantes. También se realizaron, desde la perspectiva de las diferencias de género, indagaciones sobre los tipos y grados 
de participación social, pública y comunitaria. Además, se preguntó, entre otras, acerca de la inseguridad, la situación de los jóvenes en el sector y las expectativas generales de futuro, temas que se detallan más adelante.

Algunas acciones destacadas fueron los diversos talleres de memoria colectiva; el acompañamiento en la agenda de tareas realizadas en el salón comunal del barrio Horizontes; la participación en la 17 - Semana por la Paz "El Codito, territorio de paz" en colaboración con los demás actores sociales involucrados, el apoyo al componente de madres comunitarias, entre otros. Para todo ello, la metodología de trabajo, dentro del cronograma de tareas dispuesto en el documento del proyecto, se completa con la participación activa en las reuniones del Equipo Interdisciplinario de Estudios en Desarrollo Local de la Universidad del Rosario ${ }^{2}$ y la elaboración de un compendio documental que deja constancia de las labores efectuadas.

Para la mayoría de acciones de fortalecimiento local que se desarrollan, el salón comunal de Horizontes es un punto central de referencia. En su entorno, discurren los planteamientos y propuestas de los distintos grupos organizados del sector. Bajo sus paredes se escuchan las voces de quienes tienen solicitudes, quejas y necesidades. Más allá de todo lo concreto, el salón es un espacio que nos ofrece dos puntos de interés: permite que afloren las identidades colectivas de la comunidad, que es la que lo construye, y supone un espacio abierto y receptivo a las inquietudes de todos los demás habitantes. El primero de los aspectos es manifestado por los usuarios del lugar en conversaciones grupales y perceptible, por otra parte, a partir de la actitud positiva y propositiva con que los mismos acuden a él de manera asidua. El segundo aparece cuando cobra sentido práctico la red de relaciones y vínculos entre partícipes de la comunidad y demás miembros implicados en llevar a cabo actividades en el sector. En relación a esto último son especialmente importantes los jóvenes, muchas veces interesados en talleres sobre distintas manifestaciones artísticas o deportivas, por lo general ligadas a la cultura urbana moderna, que han encontrado en el salón comunal de Horizontes un lugar donde expresarse.

2 Este equipo está conformado por diferentes dependencias de la Universidad, a saber: Facultad de Ciencia Política y Relaciones Internacionales, Escuela de Ciencias Humanas, Escuela de Medicina y Ciencias de la Salud, Cancillería e Instituto Rosarista de Acción Social —Seres—. 
El grupo más activo de adulto mayor encuentra su semana bastante ocupada en diferentes actividades. El taller viene a cubrir dos mañanas semanales en donde se ha consolidado este pequeño "trajín" de ir y venir a estas instalaciones periódicamente gracias a los beneficios que tiene en aspectos como productividad, mantenerse activos psicomotrizmente, lazos de unión, espacios para compartir y aprender, entre otros. Muchos de sus integrantes participan también de las huertas urbanas comunitarias, en la Red Sembrando Vida que viene acompañando la Cancillería de la Universidad. Como otras, se trata de cuestiones de gran importancia para sus artífices y beneficiarios/as en cuanto a la construcción de comunidad y empoderamiento participativo.

En lo relativo a la permanencia y crecimiento de las organizaciones sociales populares, es preciso preguntar qué otras razones hacen que en un momento dado, pese a las adversidades, se generen y fortalezcan procesos comunitarios. Es importante que los líderes continúen recuperando sus trayectorias para seguir avanzando en el fortalecimiento de su potencial político. Sobre este punto, la función del análisis científico-académico de la estrategia de fortalecimiento local desarrollada se materializa en una metodología pedagógica-divulgativa de los resultados obtenidos en los procesos de organización social que se vienen acompañando.

Con todo, el objetivo específico alcanzado es la consolidación de la Red Adulto Mayor, fortalecida con la realización exitosa de los distintos talleres, con la cohesión y sostenibilidad del programa productivo, preparado para afrontar la comercialización de sus productos y con los demás procesos comunitarios emprendidos en el sector. En términos generales, se ha potenciado el sentimiento de pertenencia y la participación, y fortalecido el proceso de construcción comunitaria en el sector.

\section{Memoria colectiva y procesos comunitarios}

Resulta profundamente desconcertante cuando se oye llamar memoria a la capacidad que tienen los ordenadores para conservar la información (...) conservar sin elegir no es una tarea de la memoria.

(Todorov Zvetan, Los abusos de la memoria) 
La memoria se define en relación a tiempos y espacios necesariamente insertos en relaciones de poder que, marcando el desarrollo de eventos significativos de personas y grupos, se van articulando como elementos constructores de la vida individual y comunitaria.

Proyecciones temporales y espaciales se encuadran en lugares y momentos respectivamente, entrelazando experiencias de sujetos y colectivos. "Esto eran matas, matorral, bosque, como decir, habían tres casitas, no había ningún servicio, únicamente la medio carretera que había y por ahí iban las flotas Águila para Guasca y pasaban por ejemplo tres veces al día...", comenta una vecina llegada al barrio Horizontes hace 30 años. $^{3}$

El territorio en cuanto espacio físico es una construcción colectiva definida históricamente y una práctica cultural significativa que se arraiga a la memoria a partir de efectos y experiencias individuales y comunitarias. La vinculación de los habitantes de una zona a un espacio concreto no viene dada solamente por su proximidad física, sino porque este sea parte de sus vidas cotidianas. "Cuando llegué al barrio había muy pocas casas. Yo llegué a pagar un arriendo con mis hijos", reconoce una vecina de Buenavista. Los habitantes del territorio recuerdan los lugares importantes en sus vidas a su llegada al mismo:

El lugar más importante era el centro de la Cruz Roja; que era la construcción que había ahí en toda la esquina del jardín... y estaba la Cruz Roja, y cualquier persona que se enfermara o tenía un accidente, lo llevaban y ahí lo atendían; otro, era el lugar para hacer mercado, ya le digo, a San Cristóbal, porque aquí no había; y las monjas del Colegio San Carlos, ellas venían también cada mes o cada quince días, y traían una camioneta y repartían mercados a la gente. Traían fruta, a veces pan, bolsas de carne y les daban a los más necesitados.

3 Estas y otras manifestaciones de vecinos y vecinas no identificados que aparecerán en el presente capítulo corresponden a los testimonios de varias personas en el marco de las sesiones de comunicación, registro y análisis ya mencionadas, las cuales tuvieron lugar entre la segunda semana de octubre y la tercera semana de noviembre de 2011. 
El jardín infantil, la vieja plaza de mercado, la huerta comunitaria, la cuadra de las viudas, la iglesia pasando la séptima, la quebrada de Zarauz, la quebrada de Servitá, el CAMI (Centro de Atención Médica Inmediata) de Verbenal, el Castillo o la tienda de licores de Carlos Arango son algunos de los lugares que los vecinos de los barrios identifican como significativos a lo largo de sus vidas en el sector.

Hay eventos, creencias y sentimientos que, aunque pasan por la experiencia individual son un referente colectivo y así aparecen reiteradas veces de manera central en el ideario grupal de la comunidad. Así queda demostrada la opinión de que el adulto mayor ocupa un papel de relevancia en la comunidad.

De la distinta importancia que en su contexto y valorización tienen espacios y tiempos específicos, pasados y presentes, se va generando un proceso ordenado de selección de recuerdos, sucesos y eventos significativos, y de transmisión de experiencias individuales y grupales a partir del cual se construye culturalmente la memoria colectiva. Esta resulta así, creativa y selectiva. Se conocen entonces testimonios encontrados, como los que nos transmiten unas vecinas por las calles del barrio Horizontes: "Sí, porque, por ejemplo, como dijera yo, cuando llegaba material antes de subirlo lo dejaban aquí abajo, en lo planito, donde pudiera entrar la volqueta. Entonces ya todos los vecinos le colaboraban a ayudar a subir el material, o cuando estaban haciendo plancha, haciendo una pared se les colaboraba". Mientras otra señora tajantemente reconoce: "Cuando llegué la gente no se ayudaba”, al tiempo que continúa su camino de vuelta a casa cargada con la compra del día. De esta manera, se perciben las diferencias entre el antes y el después de la construcción intersubjetiva y social de una comunidad y de su identidad en un territorio.

Por otro lado, la memoria articula una especial forma de hacer historia no necesariamente cronológica. Se comprueban con frecuencia significativas rupturas en la concepción que sobre la historia tienen los habitantes de una comunidad, pareciendo no relacionar algunos de los procesos de transformación contemporáneos con elementos organizativos del pasado en los que participaron de forma necesaria. En este sentido, las vecinas 
transmiten ciertos episodios positivos y vivencias colectivas de colaboración del pasado más reciente de la vida de sus barrios:

Hubo que hacer tomas en la autopista, paramos los dos carriles y se paró casi todo un día que se trancó todo el centro, parte de los departamentos... porque venían flotas de Tunja... de todos esos sectores... y se taponó todo eso. Fue la única manera para que el alcalde en ese momento nos parara bolas y dijera: "No, tenemos que abrir vías por ahí y no podemos dejarles cerrado por ahí porque quedan encajonados". Entonces, todo eso ha sido un proceso de lucha; no ha sido tan sencillo que nos permitan vivir un poco con una vida menos difícil.

Extrañamente no le confieren toda la relevancia que merece la construcción de los procesos organizativos actuales.

Entre los recuerdos de algunos de los vecinos aparecen testimonios de experiencias negativas en cuanto a la colaboración y solidaridad vecinal existente en aquellos años en que numerosas familias llegaban a asentarse en un territorio poco poblado. Aparecen también, ciertamente, testimonios contrarios, experiencias positivas que, de alguna manera permanecen en los recuerdos de algunos vecinos: “iClaro que sí!” responde Marina, ${ }^{4}$ vecina de Horizontes de 75 años de edad, cuando se trató la cuestión de si las familias se ayudaban o no entre sí, en los momentos en que llegaban a los barrios hasta el momento poco poblados.

Por ejemplo, cuando en esa época que no había aquí lo que se llama... yo tenía un tanque; usted sabe donde vivo yo. Ahí había un tanque y de ese tanque yo pedía el carrotanque del agua, me traía, 35, 40 galones de agua. Y yo a la gente que iba y solicitaba un galón de agua, yo se lo daba. A veces: deme 50 centavos y el resto llévelo; o así no les cobraba nada.

En general, se puede decir que los habitantes del sector se han ayudado entre sí históricamente, sentando las bases de ese progresivo proceso

4 Los nombres utilizados en el presente texto han sido cambiados. 
de construcción y reconstrucción de comunidad: "En esa época estábamos en paroid las casitas, los que quedaban vigilaban las que quedaban solas. Por la noche, por ejemplo, nos tocaba prestar vigilancia hasta muy tarde. Hombres y mujeres, entre todos. Una noche había cuatro o cinco personas para darle vuelta a todo el barrio".

En el trabajo realizado en El Codito, la memoria colectiva, manejada como una herramienta práctica, ha demostrado su utilidad para estructurar y dar continuidad a saberes y, en menor medida, para orientar hábitos y conductas. Sirve a la integración de intereses y valores sociales, políticos y culturales, lo que ayuda a incrementar la conciencia de la importancia de la organización y de la participación en la colectividad. Es, por lo tanto, fuente y además espacio del bien obrar público.

\section{El adulto mayor y la construcción de comunidad}

El anciano antes respetado se ha convertido en un pobre viejo que no sabe nada. Los esfuerzos para mejorar la calidad de vida de los ancianos/as precisa de una afectiva y empática presencia humana.

(Edgar Morín, La vía para el futuro de la humanidad)

La impresión generalizada al llegar a este cerro de calles empinadas y casas bajas es la de una intensa vida de barrio. Luego de la llegada al sector, el venido de fuera, por lo general, recibe, sin gran demora y con relativa facilidad, una agradable y calurosa acogida, si bien impregnada de cierta curiosidad desatada. Enseguida se percibe como principalmente se trata de barrios que viven, en bastante medida, de puertas para adentro. Sin embargo, es un barrio que tuvo que acogerse a sí mismo cuando se formaba, igualmente tiene a buen agrado hoy acoger al que aparece por sus calles. Así siendo las cosas, no resulta difícil entablar interesantes conversaciones en compañía de un tintico o algo de comer. Incluso las personas más introvertidas o menos habladoras nos regalan una sonrisa cuando menos.

Elevado por encima de la media de altitud del Distrito Capital, El Codito escapa al estrés e impersonalidad del trajín diario de una gran urbe, aflorando relaciones vecinales características de una comunidad diferen- 
ciada. El pequeño comercio se podría mencionar entonces como esencia palpable del trasiego de la zona. Junto a este, el llamado rebusque se puede ver desde una doble perspectiva: por un lado, resulta positivo, por cuanto permite vivir el día a día; por otro lado, perpetúa una cultura que no permite mejorar a medio plazo. Esto enlaza reflexivamente con una cuestión de fondo que afecta a los habitantes del sector, la de las escasas expectativas de futuro que, en general, impregna la vida de estos barrios y que se tratará brevemente más adelante.

Desde la experiencia personal con el grupo de adulto mayor, en las tareas desarrolladas en el sector, se pueden percibir entre las historias de los vecinos, "esclavos del concreto", algún grado, menor o mayor, de desarraigo. ${ }^{5}$ iInvasiones en llegada o despojo ilegítimo en salida? A la luz de las manifestaciones de los vecinos, parece reinar un cierto desconcierto o desconocimiento acerca del tema, reducido finalmente a la experiencia personal de cada protagonista. Este ha sido otro de los puntos principales del trabajo llevado a cabo, y que ha favorecido el que las anteriores narraciones aisladas cobrasen un sentido de conjunto.

A pesar del trabajo adelantado, se siguen identificando problemas de gravedad en el sector, entre los que destacan: la ausencia de articulación entre actores locales y entre estos y las instituciones locales presentes en la zona, la inseguridad, riesgos de desalojo, deslizamientos o drogadicción y la falta de oportunidades para los jóvenes.

En las sesiones de observación y análisis realizadas, se ponen de manifiesto estos y otros significantes destacados de la comunidad y el territorio para sus integrantes. A continuación se detallan algunos de ellos, recogiendo el imaginario y su sentir general tal y como por sus protagonistas fue expresado y transmitido:

5 Ahora bien, la cuestión del desarraigo se puede deber a variadas causas y sus consecuencias asociadas manifestarse de diferentes maneras. En el contexto que nos ocupa, la problemática se despliega fundamentalmente en relación al tema de la tierra, en una de sus versiones más agravadas, como efecto de un desplazamiento forzado. 


\section{Rutina y experiencia cotidiana}

Respecto a la rutina que siguen los adultos mayores en El Codito, desde las aproximaciones llevadas a cabo, se constata como la mayoría de hombres entrevistados suelen permanecer en sus hogares o en las calles aledañas, de forma pasiva-contemplativa y sin mostrar inquietudes ni motivación por tomar parte de la vida comunitaria más allá de esporádicos encuentros con algunos vecinos. "¿Qué más puede hacer uno de viejo y de pobre que estar todo el rato en la casita?", responde un anciano ante la atenta mirada de su mujer, un mediodía cualquiera a la entrada de su hogar en el barrio El Mirador al ser preguntados ambos si salen o no de la casa a lo largo del día. Efectivamente, teniendo la "droga", cubierta esta asistencia médica primaria, poco mueve a muchos a participar activamente en cualquier tareas del barrio, apenas saliendo para jugar un rato a naipes con algún vecino, confiesa. "Yo soy del campo. Por suerte Dios le dio a uno inteligencia para trabajar", comenta Pablo, de 69 años de edad, natural de Tolima vecino del barrio Estrellita desde hace diez años, y añade: "No puedo ir a los talleres comunales porque por la tarde me toca el 'rebusque' a la salida de los colegios".

Las mujeres de avanzada edad, en cambio, dedican sus mañanas al cuidado de sus nietos y los oficios del hogar. Así, por ejemplo, la mayoría de mujeres encontradas, se encargan de cocinar, limpiar la casa y acompañar a los niños y niñas al colegio y recogerlos. "Una lleva al nieto al colegio mientras el padre mira", cuenta una anciana en Serrezuela. En este barrio, la ruta efectúa parada frente al comedor comunitario, un lugar al que no todos pueden acceder, ya que su pretendido precio simbólico $-\$ 500$ por almuerzo infantil y $\$ 1000$ por almuerzo adulto - resulta en la práctica insostenible para muchas familias. "Hace diez años que vivo aquí y no tengo queja, pero la educación debería iniciarse desde el gobierno, porque hay gente que no come. ¿Cómo van a ir a estudiar aunque sea gratis si el transporte sí hay que pagarlo y no tienen para ello?", comenta Antonio, de 84 años de edad. "Nos ven con poco y nos dejan en paz", comenta otro adulto mayor en compañía de algunos otros con quienes acostumbra pasar las mañanas. "No tenemos dinero para pagar el almuerzo en el comedor; 
cuando hay, almorzamos en casa, y sin no hay, la pasamos sin comer y agua panelita por la noche".

Este problema es común en la mayoría de viviendas del sector. "Al que tiene una rancha ya le quitan el almuerzo que dan en los comedores... Y ese no puede quitar un ladrillo de su casa y comerlo", sentencia Pablo, de 69 años a la puerta de un bar en la carrera quinta. "Mientras uno tenga salud para trabajar", sentencia otro adulto mayor refiriéndose a sus labores personales, de su vivienda y para el autoabastecimiento mínimo necesario, "no quiero limosnear ni pedir nada a nadie. Quiero que me dejen vivir en paz".

Este adulto mayor, desplazado de Santander hasta el barrio Lomitas, en la parte alta del cerro de El Codito, refleja paradigmáticamente el sentir de quienes, pobres, viven felices. En tierra de nadie, entre el término distrital de Bogotá y competencias de La Calera, este señor, como sus vecinos, vive constantemente temeroso de sufrir derribo y desalojo por encontrarse asentado ilegalmente, de forma irregular y sin poder formalizar las escrituras de sus viviendas al habitar en zona sujeta al plan de reforestación.

\section{Sentimiento de pertenencia a la comunidad}

En primer lugar, se percibe entre las vecinas y los vecinos entrevistados un tipo de desconcierto generalizado, quienes, proviniendo en su gran mayoría de otras zonas del país, resultan no tener claro si agradecer o responsabilizar a su propia suerte por el hecho de haber recalado en estos barrios.

"Pues yo me vine para acá porque mis hijos todos se vinieron, entonces yo quede sola allá; yo no podía estarme yo sola allá, porque no había quien viera por mí, no me dejaron allá mis hijos”, cuenta Berenice, vecina de 73 años del barrio de Buenavista, llegada al sector hace más de 20 años.

Sin embargo, más allá de las razones que motivaron la llegada de cada persona al sector, el alto grado de sentimiento de pertenencia a la comunidad construida y compartida entre sus convecinos se encuentra latente entre los integrantes del grupo de adulto mayor. Comprobamos como las y los vecinos, cuando menos al interior de cada barrio, se conocen entre sí, con "nombres y apellidos" y comparten razones de pertenencia: "Hay que sopesar donde está el pueblo. Acá está. Uno va por ahí y le hablan más 
refinado", comenta el vecino Antonio; y se encuentran "más o menos" empobrecidos. "Ahorita estoy recibiendo 80000 pesitos que me dan pero eso no es mucho: que llegó el agua, que llegó la luz y iuno queda tieso!"

Una de las señoras participantes de los talleres de adulto mayor comparte el sentido que para ella tiene el concepto de lo comunitario: "Una asociación de personas que se ayudan libremente. Colaboran así como cuando las casas quedan solas, estar pendientes". Lucía, vecina de Buenavista, socializa también el significado que para ella tiene la comunidad de la que se siente partícipe: "La comunidad del barrio donde uno vive, la comunidad con las personas que uno mantiene hablando o en reuniones... Pues no es que tenga uno muchas como dice, hacer reuniones como las de aquí de tarjetería que son el día jueves, arriba el martes y los ejercicios”. Sobre este punto cabe destacar la importancia de la socialización de los usos y costumbres como atributo de lo comunitario.

Ciertas formas de relación con el entorno, en un contexto de necesidad y lucha por la mejora de las condiciones de vida se convierten así en dinamizadores de la pertenencia colectiva a una comunidad. Un buen ejemplo lo encontramos en las historias de recogida de agua en la quebrada de la zona:

Ahí hay un huequito que sale agua. Allá nos tocaba irnos de noche y eran dos, tres horas y colocar, hacer una cola, y a medida que iba corriendo la cola le iba tocando el turno, colocar el galón. Durábamos dos, tres horas para llenar un galoncito, porque el agua caía gótica a gótica. Imagínese. No podíamos ni dormir tranquilos porque había que conseguir el agua, fuera para hacer un tinto al otro día o dejarles a los chinos ahí que tuvieran de qué hacer que comer. Eso era serio.

En este y en otros hábitos rutinarios de encuentro entre los vecinos, en ciertas vivencias recurrentes en la memoria colectiva del grupo, encontramos el sentido generador del sentimiento comunitario. 


\section{Género y actitud del adulto mayor}

Una cierta pasividad y despreocupación para con muchas de las cuestiones de interés comunitario son recurrentes en una gran mayoría de personas de edad avanzada donde se encuentren y sea cual sea su condición y clase social. Se comprueba con facilidad como esta postura, tenaz e indeleble, tiene un claro componente de género, en el sentido de que se revelan especialmente tercos y obstinados los varones en comparación a las mujeres. "Yo no sé nada. Estoy enfermo. Uno no sabe nada. ¿Para qué voy a meterme?", confiesa un anciano mientras espera en la calle a que pase un autobús. En términos generales, los varones de edad avanzada son notablemente más derrotistas y carentes de fortaleza vital y animista en comparación a las mujeres mayores. Así, en los encuentros con las mujeres, estas se mostraron en su mayoría mucho más comunicativas, y declararon conocer y participar de los diferentes talleres y actividades ofrecidas por las mencionadas agrupaciones en sus barrios.

La desigualdad social entre hombres y mujeres no responde a realidades naturales o biológicas sino a asignaciones culturales de valores arraigadas en dinámicas estructurales. La escasa predisposición a participar en la vida comunitaria de los barrios es una constante generalizada entre los adultos mayores varones, así cuente el sector con bastantes asociaciones y agrupaciones que, aunque poco integradas entre sí, están comprometidas, en general, con la mejora de las condiciones de vida de sus habitantes y, en particular, con el adulto mayor. "Nosotras vamos a hacer ejercicios allí al salón comunal, entre todas las mujeres no hay sino un solo hombre", comenta una vecina. En el proceso de construcción de las casas, por ejemplo, aparecen las mujeres emprendedoras, recurso ampliamente utilizado como también los hijos protagonizan una gran participación.

Tanto los mayores en sus calles como el grupo consolidado de adulto mayor y otros vecinos de los barrios manifiestan desconocer las razones que hacen de lo anterior una situación tan frecuentemente repetida: "No se puede decir que por trabajo... Tal vez por pereza, yo no me explico por qué", nos explican en Buenavista. No obstante, algunas opiniones, que se repiten tímidamente, sí ofrecen alguna idea del sentir general al respecto. 
Luisa, vecina de Horizontes de 67 años de edad reconoce: "Yo a veces pienso que nosotras las mujeres somos más comunitarias, más serviciales, más todo, porque los hombres pues habrá unos que sí y habrá otros que no". En otras ocasiones escuchamos con algo más de firmeza: "Por perezosos, porque las señoras tienen más juicio que los señores. Ahora los señores a las tiendas a tomar y eso. Ya no, ya somos las mujercitas las que se ajuntan". $\mathrm{O}$ también: "Por una parte las mujeres somos como las más organizadas (...) de los grupos, los hombres lo que pasa es que son más reacios a todas estas situaciones porque dicen que son para mujeres (...) Los ejercicios, la escuela del cuerpo, el no sé qué, los bailes, todo eso, eso es para mujeres. Es una ideología que se tiene". O más sencillamente: "Nosotras las mujeres somos más responsables".

\section{Participación y desconfianza en las instituciones}

"Se tiene la necesidad, digamos todavía, deficiencia que no están legalizados... por ejemplo aquí en el barrio Horizontes hacia arriba terminando El Mirador, que hay una gran población, hombres, mujeres, niñas, niños, que carecen de servicios públicos. No tienen agua, no tienen es servicio..." afirma Martha, natural de Boyacá, lideresa comunitaria que lleva años trabajando en las instituciones públicas y con las comunidades por el desarrollo local. ${ }^{6}$

Lo que se dice, porque no están legalizados es que no tienen los servicios, pero hace más o menos unos diez años que hemos estado algunas organizaciones muy pendientes para que les legalicen aunque sea el agua, pero no ha sido posible, ni el Estado, ni el Gobierno, ni la Alcaldía, ni que ninguno pare bolas... Lo que pasa es que allí de fondo hay otras situaciones que hay intereses personales porque hay ahí unas fincas muy

6 Ha sido miembro del Comité de Negociación con organizaciones a nivel distrital de la Secretaría de Integración Social. Actualmente, trabaja en Copevisa (área de promoción social), es representante de la Red de Mujeres de la localidad Usaquén; consejera Cultural de la Secretaría de Cultura, Mujer y Género; y participa en la Unidad Productiva de Unipulpas y en obras teatrales con la comunidad en el sector. 
grandes de unos propietarios muy pudientes (...) con la Alcaldía se ha intentado trabajar bastante, pero muchas de las veces es un caminito para lograr que paren bolas, que realmente se interesen; pues en algunos momentos se interesan pero vuelven a bajar la guardia, toca estar haciendo lobby permanentemente; pedir citas con un mes de anticipación. Muchas veces va uno a solicitar y pierde lo del transporte y su tiempo.

Relatos como este y otros de corte distinto evidencian como cada persona evalúa la gestión de las entidades públicas de acuerdo con el grado de representatividad que observa en las instituciones. Entre los testimonios de sus habitantes se encuentran ejemplos de vecinos menos comprometidos con el trabajo comunitario para quienes los procesos de construcción de sus casas se deben primordialmente al trabajo de la corporación pública y empresas privadas. Más allá de las tareas de gestión que lleva a cabo la administración para cubrir las necesidades básicas insatisfechas de la población, tras el desarrollo urbanístico y organizacional del barrio, se destaca la iniciativa de la comunidad por encima de la iniciativa misma de las empresas distritales y entes gubernamentales.

Algunos de los habitantes del barrio se apropian más de la historia del mismo como un proceso conjunto de desarrollo. Sus primeros habitantes, quienes llevan hoy ya más de 30 años residiendo en él, participaron activamente en la lucha por los servicios al tiempo que construían poco a poco sus casas. El estudio de los relatos de los vecinos y vecinas de distintos barrios muestra, por ejemplo, en lo que respecta a la construcción de espacios comunes, como, gracias a la Junta de Acción Comunal, se avanzó notablemente. "No, hasta hace nada, hará como unos diez años que... por la Junta Comunal ya se empezó a ayudar para los proyectos como de las escaleras y esas cosas", explica una vecina de Buenavista al respecto.

\section{Inseguridad}

Al estudiar la elevada inseguridad que se vive en el sector nos encontramos con reflexiones como la que sigue: "Siempre ha sido, pero se va agudizando, es a partir de los desplazamientos, de las violencias que hay en los 
departamentos, entonces ya llegan, digamos, los desplazados, desplazadas y sus familias, mucha población de migraciones; la situación económica se agudiza, y eso hace que se levante una inseguridad tenaz".

En los barrios se dan hechos que son altamente preocupantes, como los altos índices de drogadicción, vandalismo y delincuencia y mal uso de los espacios públicos. Estos generan una percepción muy negativa de la seguridad. "El principal problema acá es la inseguridad, como en otras partes de Bogotá, sobre todo 'ahí arriba' porque no llega la policía”, señala Pablo, vecino del barrio Estrellita refiriéndose a las zonas altas del cerro. "Sólo si la llamas — continúa-y llegan tarde, y por ahí hay mucho vicio, y por el vicio la gente roba y hasta mata". Al preguntar cómo vive esta situación personalmente responde: "Al principio mal, pero ahora ya me conocen y me respetan más, y no tengo problemas porque acá ya desde que está el CAI —refiriéndose a la unidad ubicada en la carrera cuarta — todo va mejor. Al hablar de las familias problemáticas que habitan el sector, enseguida por ejemplo salen a relucir "Los Héroes? — reconocen—Son bien renombrados. ¡Ay sí! Muy vengativos. Muy buscarruidos. Y es que ellos se forman como una pandilla. Sí, pandilleros".

Aunque el sector se registre de facto especialmente vulnerable en términos de inseguridad, una de las cuestiones de primer orden de importancia en el territorio es la relativa a la construcción de paz. La comunidad viene insistiendo y centrando sus esfuerzos en generar espacios y mostrarse como "territorio de paz". Ahora bien, la paz entendida en sentido amplio implica la existencia de posibilidades de futuro, la suficiencia de fuentes y volumen de ingresos familiares mensuales. Además, las posibilidades de realización de los proyectos de vida y libre desarrollo digno de la personalidad requieren de la no violencia social y administrativa. Es entonces cuando no todo depende de la buena voluntad comunitaria como tal. El siguiente comentario ilustra lo anterior con meridiana claridad:

Por ejemplo trabajar, la mamá cabeza de familia, tiene cuatro o cinco hijitos, viven en una piecita, va a trabajar por días y sus niños quedan

$7 \quad$ El nombre ha sido modificado 
solos todo el día. ¿Qué hacen? iQué hacen en la calle! ¿Qué costumbres? ¿Quién los educa? ¿Quién los orienta? Esas costumbres que ellos van adquiriendo, van mirando alternativas que ellos ven en la noche; porque es la única alternativa de cómo sobrevivir. Si tienen hambre, ¿qué hago?, me meto en una panadería y me robo un pan aun que sea, ¿cierto? A medida que esas situaciones que se han venido presentando y se ha elevado la inseguridad. Ellos se acostumbran a vivir de esa manera más fácil sin trabajar y entonces ya no quieren trabajar. Así se les busque trabajo, ya no quieren trabajar porque esa es su costumbre. Aunque es una situación bien difícil para ellos porque se exponen permanentemente, pero igual esa es la situación de ellos.

\section{Conclusión}

Sólo una comunidad empoderada, que se apropia del territorio puede participar públicamente en aras del progreso social de la ciudadanía.

Una ciudad digna debe asegurar para sus habitantes condiciones de autonomía, convivialidad, solidaridad y seguridad. El PNUD ${ }^{8}$ ha definido reiterativamente la exclusión de la participación en la vida pública y política como la más relevante forma de exclusión. La participación va ligada íntimamente a la importancia de fomentar el sentimiento de pertenencia, y esta a su vez está directamente vinculada a la generalización de los derechos de ciudadanía a todas las personas. En todo caso, el aprovechamiento de los mecanismos de participación ciudadana que el Estado ofrece se convierte en una necesidad.

El libre desarrollo de la cultura y de las personalidades y colectividades se debe expresar en eventos propiciados por el Estado pero planeados y desarrollados por la comunidad. Existe, sin embargo, una fuerte apatía de la población hacia los mecanismos institucionales de participación.

En cuanto a las relaciones comunitarias y el estado actual del proceso de capacitación para la participación pública e interlocución e incidencia

$8 \quad$ Programa de las Naciones Unidas para el Desarrollo 
sociopolítica, tal vez el sector no esté aún en condiciones de empoderamiento suficiente como para expandir libre y anchamente su proyección social, para desplegar su "participación pública" (condición quizá reservada en exclusiva a estratos superiores). A este respecto, los procesos colectivos son aún demasiado débiles y desarticulados, lo que conlleva a que no se logre la solución de los problemas del sector. Se precisa una mayor toma de partido del entorno ciudadano en el espacio público y político, esto es, con vocación de influir en él. No se trata de una mera presencia, información o colaboración, sino de una intervención responsable, una involucración de los sujetos en los grupos en donde ambos se influyan recíprocamente e influyan, a su vez, en las instancias de gobierno y administración.

La voluntad (querer) y la capacidad (saber-poder-hacer) de desarrollo, ambos se han ido fortaleciendo y dinamizando gracias al trabajo adelantado. A pesar de ello, la comunidad no alcanza la anterior condición deseable, no tanto por falta de capacidad, cuando menos potencial y por desarrollar, cuanto por otros obstáculos, internos y externos, que aún impiden que se materialice real y efectivamente. El objetivo último radica en alcanzar ese uso extendido y extensivo de la democracia que el Estado social de derecho debe permitir y perseguir. ${ }^{9}$ Sin embargo, este ideal está aún lejano de la realidad de El Codito. La realidad presente y las previsiones de cara al futuro más inmediato, aún apuntan en sentido contrario.

En todo caso, el hecho de que lo anterior pueda operar tan sólo a largo plazo no ha de desorientar el punto de mira y desencaminar los esfuerzos operados en esa dirección. Muchos poderes públicos locales parecen también haber entendido que "cada vez es más difícil gobernar sin tener en consideración las voces que claman desde las bases, sin dar escucha a sus calles", de manera que se vienen mostrando receptivos a tener en cuenta las demandas de la sociedad civil organizada. Esta está llamada a gestionar las políticas públicas que les atañen, a ser un actor de la buena gobernanza urbana junto a políticos, administrativos y demás servidores públicos locales. El elenco de agentes sociales debe favorecer a nivel local la estimulación de

9 Con mayor o menor grado de idealismo, o, si se prefiere, de suerte de impotencia a priori proclamada y garantizada. 
ese potencial humano, verdaderos focos de creatividad e innovación social. Hoy ha quedado ya patente la capacidad de inventiva de los colectivos más pobres de las grandes ciudades de los países en desarrollo.

Inicialmente, las comunidades se organizan solo por una cuestión de falta de techo, pero a continuación lo hacen por las problemáticas de salud, recreación, seguridad, cultura y demás ámbitos de la vida comunitaria, incluyendo el conjunto de cuestiones contradictorias en torno a la figura del joven y su acceso a oportunidades dignas. Sin embargo, una vez satisfechas las necesidades vitales más acuciantes y las primeras aspiraciones materiales, las comunidades, habiendo medrado en sus situaciones personales, familiares y laborales, viran progresivamente hacia una creciente despolitización, en lo que supone clara merma de la fortaleza y capacidad de los citados proyectos de lucha por la emancipación social y ciudadana y la construcción de una Colombia más justa e igualitaria. Con la estructuración e institucionalización de la vida social, el individuo deja de ser actor en la historia y pierde su capacidad de transformación, su protagonismo, su memoria. Ciertamente, el encontrarse en semejante condición, cuando va acompañado de padecimientos e injusticias, favorece el que nunca se apague la mecha de ciertas luchas y procesos reivindicativos por parte de los grupos más desfavorecidos. En la mayoría de ocasiones, es en estos donde con mayor magnitud se mantienen avivadas las relaciones de solidaridad vecinal, precisamente perdidas en el transcurso del crecimiento desordenado y asfixiante de las urbes.

A la relativa desvinculación de los procesos comunitarios que viven los barrios toda vez que sus integrantes, además de desentenderse de sus procesos reivindicativos, se van desplazando a vivir a otros lugares, hay que añadir, en detrimento de la calidad de vida de los mismos, la problemática de delincuencia organizada y microtráfico de estupefacientes que viven.

En un contexto de sufrimientos, contradicciones y conflictos, de pérdida de referentes identitarios que dificulta la construcción de los procesos de organización y participación ciudadana en una comunidad, la memoria, la reflexión y la acción colectiva resultan elementos decisivos en la lectura de las dinámicas y transformaciones sociales y en el fortalecimiento de los procesos de desarrollo local. Por un lado, como producción de conocimien- 
to e imaginario sobre el pasado, útil reflejo de las lógicas, preocupaciones, problemáticas y aspiraciones de los sujetos de una comunidad en "cada presente". A través de las experiencias de lucha social y organizacionales se reactivan vínculos y se potencian las subjetividades. De esta forma, las masas populares escriben la parte de la historia que se les deja, los "subalternos" representan su propia historia. A los efectos de la reconstrucción colectiva de la historia compartida en un grupo dado, no importa tanto la exactitud o propiedad técnico-historicista, como sí el "por qué" de los sujetos que reconstruyen su pasado, sus cómos y sus cuándos. "Ponerse en el imaginario de", especialmente del adulto mayor, cuyo papel es vital en el relevo generacional.

Por otro lado, como constructor de una ciudadanía consciente, comprometida y empoderada sociopolíticamente, la participación ciudadana es el producto del largo y complejo proceso de construcción histórica que conduce a la generación de conciencia e identidades socialmente definidas y consolidadas. La acción de construir procesos identitarios es en sí misma una acción de fortalecimiento democrático. Sin el fortalecimiento de estos procesos, en y desde la colectividad local, la ciudadanía no cuenta con el escenario mínimo necesario para emanciparse en su proceso de desarrollo.

\section{Bibliografía}

Del Valle, T. (2005) El espacio y el tiempo en las relaciones de género. Recuperado de http://www.archivochile.com/Mov_sociales/mov_mujeres/doc_gen_cl/ MSdocgencl0006.pdf

Franco F. (2008). Construcción cultural del territorio desde lo popular: cotidianidad y proyectos de futuro en Bogotá y Soacha. Bogotá: Escuela Superior de Administración Pública-ESAP.

Hernández M. (septiembre-noviembre de 2011). [Entrevistas semiestructuradas a las integrantes de la Red Adulto Mayor].

Hernández M. (octubre-noviembre de 2011). [Sesiones de comunicación, registro y análisis, con vecinos y vecinas adultos mayor de los barrios de El Mirador, El Codito, Serrezuela, Lomitas, Capilla y Horizontes]. 
Morín, E. (2011). La vía, para el futuro de la humanidad. Barcelona: Paidós Iberoamérica.

Portal M. A. (2006). Espacio, tiempo y memoria. Identidad barrial en la ciudad de México: el caso del barrio de La Fama, Tlalpan. En Rodríguez P. \& Aguilar M. A. (Coord.), Pensar y habitar la ciudad: afectividad, memoria y significado (pp. 69-86). Barcelona: Editorial Anthropos.

Ramírez, L. (et al). (2009). Análisis de contexto local: Usaquén-Bogotá. Bogotá D. C., Colombia: NC Falta nombre de la editorial.

Todorov, S. (2008). Los abusos de la memoria. El arco de Ulises. Madrid: Ediciones Paidós.

Torres, A. (2007). Organizaciones populares y luchas urbanas en Bogotá 1980-2000. Construcción de identidad y acción política. Bogotá: Universidad Pedagógica Nacional. (Colección Ciencias Sociales).

Vizer, E. A. (2002). Metodología de intervención en la práctica comunitaria: investigación-acción, capital y cultivo social. Ciberlegenda, (10).

Wacquant, L. (2007). Los condenados de la ciudad, gueto, periferias y Estado. Buenos Aires: Siglo XXI Editores. 


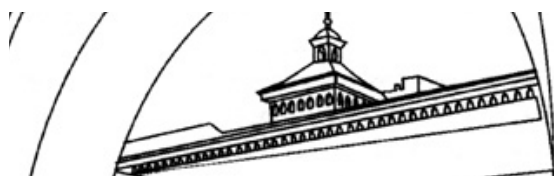




\section{Conclusión general}


La urbanización de Bogotá se ha desarrollado de forma acelerada y, en ocasiones, no muy planificada, lo que sin duda genera conflictos y situaciones de compleja solución y abordaje. Las dinámicas de poblamiento, uso de suelos, extracción y conservación de los cerros orientales, no escapan a esta situación y muy por el contrario son una clara muestra de todas estas paradojas. Este es el escenario de El Codito.

El proceso histórico de su conformación, enmarcado en la dinámica de crecimiento y desarrollo de la ciudad, ha estado determinado por factores ligados al conflicto, la abundante y confusa normatividad, la confrontación, el asistencialismo, la exclusión y los imaginarios negativos, por parte de otros sectores de Bogotá. De esta manera, estos barrios, comparten con otros de la ciudad, dinámicas y problemáticas similares, en cuanto a procesos de poblamiento, acceso a servicios públicos, ofertas laborales, educativas o de salud y oportunidades para la participación. ${ }^{1}$ Sin embargo, como se encontró en la investigación, cada barrio tiene sus dinámicas particulares y ha cimentado su historia, con base a hechos, personajes y construcciones simbólicas diferentes. Todo este proceso y la red de relaciones que se genera en cada territorio determinado, permiten la conformación de prácticas que significan y delimitan una comunidad.

Así, a través de la revisión de literatura sobre la historia del sector El Codito y de información obtenida de fuentes primarias, por medio de entrevistas semidirigidas y charlas informales, esta investigación pretendió reconstruir los hitos, rescatar el papel de los protagonistas y determinar la importancia del territorio, en la construcción de comunidad. En este sentido, fue fundamental el apoyo ofrecido por los adultos mayores del sector, que como miembros fundantes de la comunidad, compartieron sus experiencias, sus recuerdos y sus sentimientos frente al territorio que les ha brindado alegrías, tristezas y oportunidades. Este mismo territorio, escenario en el que confluyen intereses y contradicciones, es, al mismo tiempo, una zona estratégica para la ciudad, en términos ambientales y de sostenibilidad, y

$\mathrm{Al}$ respecto, cabe recordar que Bogotá, al igual que otras ciudades como Medellín y Cali, se consolida y se sigue consolidando como centro receptor de migrantes y personas en situación de desplazamiento, que llegan en busca de mejores y nuevas oportunidades. 
lugar de residencia y desarrollo, para miles de personas que han puesto allí sus esperanzas y proyectos de vida. Tal vez por ello, pese a esfuerzos como los adelantados por la Mesa Ambiental de los Cerros Orientales, no se ha logrado un consenso frente a la naturaleza y uso de los cerros orientales, lo que, por demás, mantiene a sus pobladores en un estado de constante incertidumbre.

Así, la cotidianidad de El Codito, pareciera estar enmarcada en un escenario de permanente conflicto y desconfianza, que se intensifica con situaciones reconocidas por sus pobladores, como la inseguridad y las diversas manifestaciones de violencia. Este contexto, por supuesto, determina las relaciones de la comunidad con las instituciones distritales y estatales y con los actores externos que por diversos motivos allí confluyen.

Recalcamos, sin embargo, que lo que denominamos 'comunidad' dista mucho de la concepción tradicional, que a ella le fue otorgada, y, más bien, hace referencia a un conjunto de prácticas, saberes y sentires, que son reconocidos y legitimados por algunos pobladores del sector, y que, en ocasiones, siguen identificándose con los principios de cohesión social, solidaridad y territorio. Vale la pena resaltar la importancia que se le otorga a la participación, tanto en espacios comunitarios, como en actividades y eventos propuestos por instituciones oficiales, privadas y no gubernamentales; es justamente esta participación la que ha permitido y sigue permitiendo grandes avances en el desarrollo local. Tal vez el mayor de estos avances, tal como lo entienden sus pobladores, fue el proceso que llevó a la consecución de servicios públicos, un hecho recordado y recurrente, en el momento de construir la memoria histórica de los barrios. Estos hechos, no obstante, también nos llevaron a concluir que se puede hablar de comunidad, siempre que haya una situación coyuntural que amerite la unión y consenso de los pobladores, pero, que una vez solucionada dicha situación, se retorna a un ambiente de generalizada despolitización, eximiendo ciertos casos y personajes concretos, que siempre están involucrados en los asuntos comunitarios.

Al propender por fortalecer los espacios de participación y siempre con un ánimo de empoderamiento comunitario, la Universidad del Rosario ha decidido hacer presencia en este territorio desde el año 2007, a través de 
128

diversos proyectos y estrategias, que se inscriben dentro de sus políticas de responsabilidad social universitaria.

Esta publicación, fruto de este trabajo, ha sido posible gracias al apoyo de los líderes y lideresas del sector, de diferentes organizaciones que hacen presencia en el territorio, de los jóvenes y adultos mayores que compartieron con nosotros sus experiencias, añoranzas y recuerdos. 


\section{5 360ános}

\section{Editorial Universidad del Rosario 15 años}

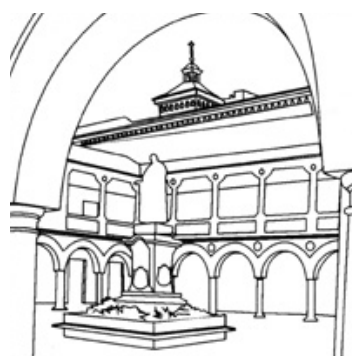

Este libro fue compuesto en caracteres GoudyOlSt BT 12 puntos, impreso sobre papel propal de 70 gramos y encuadernado con método Hot Melt, en el mes de mayo de 2013, en Bogotá D. C., Colombia Xpress. Estudio Gráfico y Digital 